$\frac{4}{1 / 3} \cdot 985(2)$

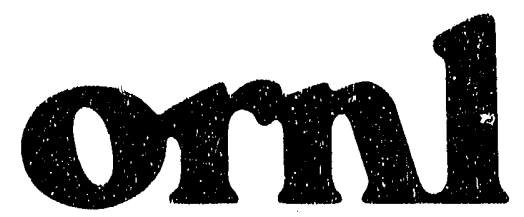

OAK RIDGE NATIONAL LABORATORY

MARTUN MARITETRA

\title{
ORNL-6693
}

Health and Safety Research Division

Progress Report for the Period April 1, 1990 - September 30, 1991

Stephen V. Kaye

MANAGED BY

MARTIN MARIETTA ENERGY SYSTEMS, INC.

FOR THE UNITED STATES

DEPARTMENT OF ENERGY 
This report has been reproduced directly from the best available copy.

Avallable to DOE and DOE contractors from the Office of Scientific and Techrical Information, P.O. Box 62, Oak Ridge, TN 37831; prices availlable from (615) 576-8401, FTS 626-8401.

Available to the public from the National Technical Information Service, U.S. Department of Commerce, 5285 Port Royal Rd., Springfield, VA 22161.

This report was prepared as an account of work sponscred by an agency of the United States Government. Neither the United States Government nor any agency thereof, nor any of their employees, makes any warranty, express or implied, or assumes any legal liability or responsibility for the accuracy, completeness, or usefulness of any information, apparatus, product, or process disclosed, or represents that its use would not infringe privately owned rights. Reference herein to any specific commercial product, process, or service by trade name, trademark, manufacturer, or otherwise, does not necessarily conetitute or imply its endorsement, recommendation, or favoring by the United States Government or any agency thereof. The views and opinions of authore expressed herein do not necessarily state or reflect those of the United States Goyernment or any agency thereof. 
Dist. DE92 01035?

\title{
HEALTH AND SAFETY RESEARCH DIVISION PROGRESS REPORT FOR THE PERIOD April 1, 1990 - September 30, 1991
}

\author{
Stephen V. Kaye
}

Director

Date published: March 1992

OAK RIDGE NATIONAL LABORATORY

Oak Ridge, Tennessee 37831-6285 managed by

Martin Marietta Energy Systems, Inc. for the DEPARTMENT OF ENERGY under Contract No. DE-AC05-84OR21400 


\section{HEALTH AND SAFETY RESEARCH DIVISION \\ PROGRESS REPORT FOR THE PERIOD \\ April 1, 1990-September 30, 1991 \\ CONTENTS}

FOREWORD $\ldots \ldots \ldots \ldots \ldots \ldots \ldots \ldots \ldots \ldots \ldots \ldots$

1. ASSESSMENT TECHNOLOGY SECTION $\ldots \ldots \ldots \ldots \ldots 1$

Measurement Applications and Development $\quad \ldots \ldots \ldots \ldots \ldots$

Follutant Assessments . . . . . . . . . . . . . . . . . . 7

Measurement Systems Research $\ldots \ldots \ldots \ldots \ldots$

Dosimetry Applications Research $\ldots \ldots \ldots \ldots \ldots \ldots$

Metabolism and Dosimetry Research . . . . . . . . . . . . . . 12

Nuclear Medicine $\ldots \ldots \ldots \ldots \ldots \ldots \ldots \ldots$

2. BIOLOGICAL AND RADIATION PHYSICS SECTION $\ldots \ldots 17$

Atomic, Molecular, and High Voltage Physics $\ldots \ldots \ldots . . . . . .19$

Physics of Solids and Macromolecules . . . . . . . . . . . . 20

Liquid and Submicron Physics . . . . . . . . . . . . . . 23

Analytic Dosimetry and Surface Physics . . . . . . . . . . . . . 24

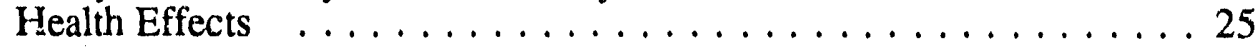

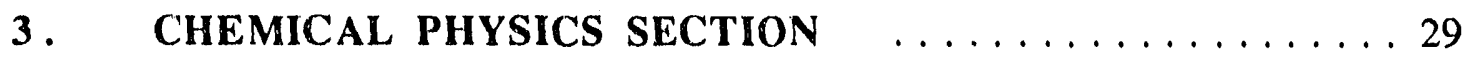

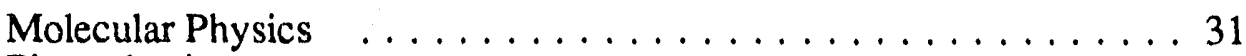

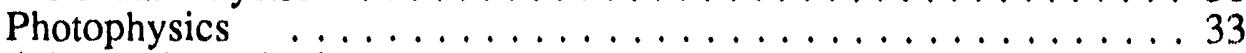

Advanced Monitoring Development $\ldots \ldots \ldots \ldots$. . . . . . 34

4. BIOMEDICAL AND ENVIRONMENTAL

INFORMATION ANALYSIS SECTION $\ldots \ldots \ldots \ldots, 37$

Human Genome and Toxicology $\ldots . . . . . . . . . . . . . .40$

Chemical Hazard Evaluation and Communication . . . . . . . . . . 42

Environmental Regulations and Remediation $\ldots \ldots \ldots \ldots \ldots$

Information Management Technology . . . . . . . . . . . . . . 45

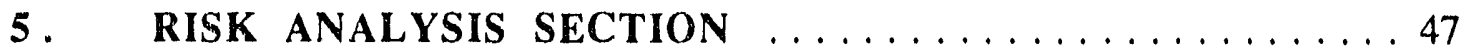

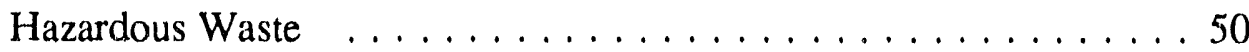

6. CENTER FOR RISK MANAGEMENT $\ldots \ldots \ldots \ldots \ldots 51$

7. CONTRIBUTIONS TO NATIONAL AND LEAD

LABORATORY PROGRAMS AND ASSIGNMENTS-

ENVIRONMENTAL RESTORATION $\ldots \ldots \ldots \ldots \ldots 53$ 


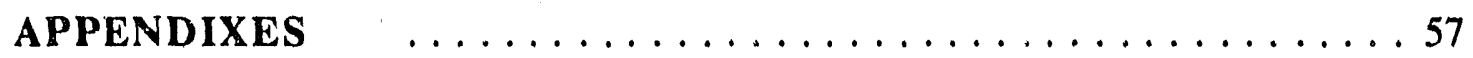

APPENDIX A. Sources of Funding $\ldots \ldots \ldots \ldots \ldots \ldots \ldots \ldots \ldots$

APPENDIX B. Personnel Summary $\ldots \ldots \ldots \ldots \ldots \ldots \ldots \ldots \ldots 6$

APPENDIX C. Crganization Chart $\ldots \ldots \ldots \ldots \ldots \ldots \ldots \ldots \ldots 63$

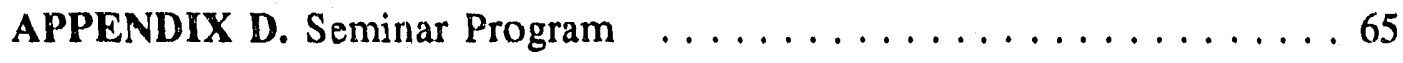

APPENDIX E. List of Honors and Awards for Staff Members . . . . . . . 69

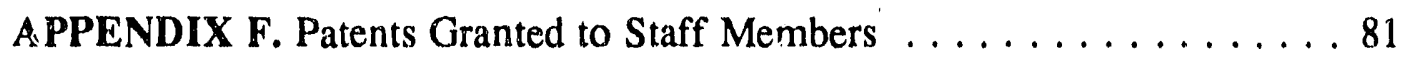

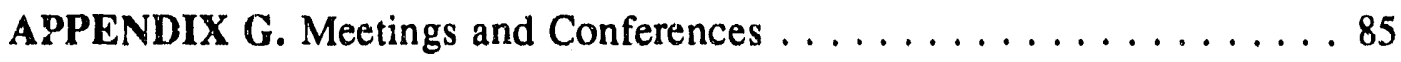

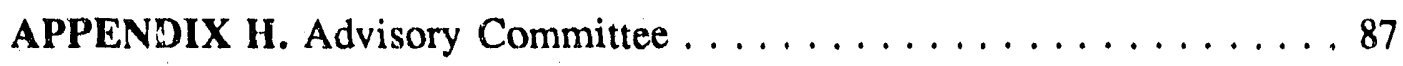

APPENDIX I. Presertations $\ldots \ldots \ldots \ldots \ldots \ldots \ldots \ldots \ldots$. 89

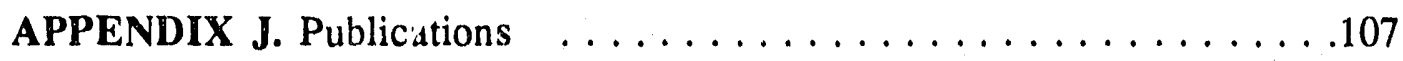




\section{FOREWORD}

\section{Stephen V. Kaye}

The programs of the Health and Safety Research Division (HASRD) encompass applied and basic research conducted both in the field and in the laboratory. In addition, the Division is involved in information management and health risk assessments. These activities support our purpose and mission which is to provide a sound scientific basis for the measurement and assessment of human health impacts of radiological and chernical substarces. The breadth of our overall program is a strength which ranges from atomic and molecular resolution of challenging problems to a macroscopic focus on man as the receptor of impacts and increased health risks due to different energy' technologies. Our progress during the period covered by this report (April 1, 1990, through September 30, 1991) is well documented by open-literature publications, oral presentations, computer data bases and information systems, educational contributions, and service in professional organizations. Various internal and external awards and other citations provide assurance that this work represents a creative addition to scientific knowledge.

A major realignment of the Division's organizational structure has provided more focused capabilities to achieve our purpose and mission. This did not involve changes within groups, only realignments at the section level.

The new position of Associate Division Director was filled by Barry Berven. His ridjor icsponsibilities include strategic planning, technology transfer, self assessment, and assisting the Division Director in all line management functions. Berven has extensive management and field experience from his previous position as Head of the Environmental Measurements and Applications Section. The Office of Risk Analysis led by Curtis Travis was dissolved, and the Risk Analysis Section was formed in its place. Robin White was named Group Leader of the Section's Hazardous Waste Group, which provides major risk analysis assistance to the Martin Marietta Environmental Restoration Program. Mary W. Francis was also named as Group Leader in the Biomedical and Environmental Information Analysis (BEIA) Section to provide vital assistance in Energy Systems and ORNL environmental safety annd health compliance issues. Paul Rohwer transferred to HASRD to become Head of the Assessment Technology Section after serving for several years as the Oak Ridge National Laboratory (ORNL) Environmental Coordinator. The Health Studies Section (HSS) was assimilated by other sections 
following the departure of Alan Hawthorne, former Head of HSS. He did an excellent job of providing leadership for the Section for over three years. The four Groups in the Section were realigned as follows: The Nuclear Medicine Group and the Metabolism and Dosimetry Group were moved to the Assessment Technology Section; the Health Effects Group was transferred to the Biological and Radiation Physics Section; and the Advanced Monitoring Development Group became a part of the Chemical Physics Section. A current organization chart of the Division is included in the appendix to this progress report.

Health risk assessments continued to be a major activity for the Division in basic methodology development as well as in risk analysis applications of local and national importance. This capability of HASRD and several other ORNL divisions was brought to better focus by the creation of the ORNL Center for Risk Management under the ORNL Associate Director for Environmental, Life, and Social Sciences. The new Center is headed by Curtis Travis and utilizes staff from HASRD and several other ORNL divisions. An important activity of the Center is to provide support to the Environmental Restoration Program and other major Department of Energy programs in environment, safety, and health. Our goal is to attain national recognition for the Center, which combines scientific talents at the Laboratory in health, environmental, social, and economic analysis to successfully address major risk-related problems that result from energy technologies.

Loucas Christophorou was named a Senior Corporate Research Fellow of Martin Marietta Energy Systems, Inc. His appointment recognizes a career of outstanding accomplishments in molecular, radiation, and discharge physics. He thus has joined the select few in Energy Systems who have attained the highest level possible for a scientist at ORNL.

Division staff have continued to win recognition for extraordinary creativity in basic research and in applied programs. During the reporting period, seven patents were awarded for a variety of inventions that ranged from a radiopharmaceutical product to an optical data storage device based on surface enhanced Raman absorption spectroscopy. Two R\&D 100 awards were won by HASRD staff. Mark Buckner shared an R\&D 100 award for a new radiation dosimetry reader system, and Prem Srivastava earned the other for an innovative radiolabeling compound for attaching and retaining radioactive iodine on proteins and tumor-specific antibodies while maintaining their intended functions. Their achievements bring the Division's total to eleven R\&D 100 awards in the past eleven years! 
In 1985, the Division established the Excellence in Research Award to be presented annually to a HASRD staff member for achievement in either applied research (evennumbered years) or basic research (odd-numbered years). The award is given for creative and innovative contributions to science as judged by a panel of senior ORNL staff. C. H. (Winston) Chen was the 1990 recipient for his development of a variety of innovative measuring devices including, but not limited to, new fluorocarbon detectors.

The Distinguished Achievement Award instituted in 1989 for support staff was awarded to four individuals during the 18 months covered by this report. The 1990 and 1991 Distinguished Achievement Awards for Administrative Support were presented to Debbie Barslund and Brenda Ramsey, respectively. The 1990 and 1991 Distinguished Achievement Awards for Technical Support were presented to Jim Thate and Marilyn Langston, respectively. These awards help to bring focus on the vital role played by the Division's support personnel in all aspects of our programs, but especially in relation to successful teamwork between research and support staff.

Four HASRD staff members were honored during Energy Systems Awards Night ceremonies for outstanding achievements in 1990. P. C. (Prem) Srivastava received the Publication Award for a paper describing a new radioiodine tagging system for nuclear medicine applications. Steve Allman and Ron Phillips shared the Technical Achievement Award for their collaboration in implementing resonance ionization spectroscopy applications. The Operations and Support Award was presented to Paul Rohwer for contributions to development and implementation of an innovative internal health physics technician training program.

Other noteworthy awards include Senior U.S. Scientist Awards from the Alexander von Humboldt Foundation for collaborative research in Germany received by both Loucas Christophorou and Russ Knapp. Christophorou is involved in a year of collaborative research on excited states of liquids, and Knapp is pursuing laboratory and clinical application of radiopharmaceuticals developed in HASRD. In addition, Jim Turner was invited to spend four weeks at the Institut fur Strahlenschutz, Forschungszentrum fur Umwelt und Gesundheit, Germany, to initiate long-term collaborative studies on the quantification of radiation interactions for describing biological effects.

Kowetha Davidson and Robert Young were appointed Diplomates of the American Board of Toxicology. Certification was earned after successfully completing a comprehensive written examination as well as satisfying other requirements based on toxicology experience. This recognition not only enhances their cal : srs, but also reflects 
well on the toxicological analyses and data bases produced by the BEIA Section of HASRD.

The Division enjoys a leadership position in several important areas of R\&D and has organized and sponsored six major symposia and conferences. These successful meetings helped promote exchange of scientific information with researchers fror: other institutions while at the same time served to maintain the reputation of HASRD and ORNL in the scientific community.

Overall, there was little change in the number of staff or total budget since the previous reporting period. However, the composition of our program continued to change in favor of risk analysis, site characterization, envirolimental assessments, information management, and other applied areas, while basic research was static in number of staff and budget. In order to maintain successful basic research programs, we have found that it is necessary to devote much more effort on marketing and justifying new requests for support. We expect this trend to continue for some time. Other important factors and needs have been identified in our strategic and long range planning process. Among these are inadequate facilities, lack of sufficient young staff in our basic physical science programs, difficulty in recruiting qualified staff in certain disciplines needed for hazardous waste and environmental restoration projects, and inadequate capital equipment funds to purchase the equipment and computers necessary for maintaining excellence.

By all indications, the Division's programs remain competitive along a broad scientific front and enjoy Leadership positions in our strongest areas. Science is an exciting business that must be constantly changing to be competitive. These changes in our programs are seen as the necessary response to challenges that we must meet to maintain our status as a first-class research organization. The excitement of discovery and the successful completion of projects are among the rewards we seek. 


\title{
1. ASSESSMENT TECHNOLOGY SECTION
}

\author{
P. S. Rohwer, Head
}

Staff

Fiesearch:

$\begin{array}{ll}\text { K. R. Ambrose } & \text { D. C. Landguth } \\ \text { B. A. Berven } & \text { R. W. Leggett } \\ \text { P. A. Brimer } & \text { C. A. Little } \\ \text { D. E. Bohrman } & \text { L. M. McDowell-Boyer } \\ \text { K. J. Brown } & \text { D. W. McPherson } \\ \text { M. A. Buckner } & \text { S. Mirzadeh } \\ \text { A. P. Callahan } & \text { C. A. Muhr } \\ \text { R. F. Carrier } & \text { N. B. Munro } \\ \text { W. H. Casson } & \text { M. E. Murray } \\ \text { W. D. Cottrell } & \text { J. E. Nyquist } \\ \text { M. T. Cristy } & \text { J. E. Peterson } \\ \text { T. A. Cronk } & \text { D. A. Pickering } \\ \text { K. S. Dickerson } & \text { R. E. Rodriguez } \\ \text { C. S. Dudney } & \text { C. S. Sims } \\ \text { M. L. Espegren } & \text { P. C. Srivastava } \\ \text { D. E. Fields } & \text { D. R. Smuin } \\ \text { R. D. Foley } & \text { G. H. Stevens } \\ \text { R. B. Gammage } & \text { R. E. Swaja } \\ \text { F. G. Gardner } & \text { J. E. Thate } \\ \text { D. W. Greene } & \text { D. J. Thorne } \\ \text { J. W. Haas, III } & \text { E. A. Wachter } \\ \text { D. K. Halford } & \text { S. J. Wallace } \\ \text { S. C. Hall } & \text { J. K. Williams } \\ \text { C. A. Johnson } & \text { D. L. Wilson } \\ \text { G. D. Kerr } & \text { M. J. Wilson } \\ \text { F. F. Knapp, Jr. } & \text { D. A. Witt } \\ \text { D. C. Kocher } & \text { K. M. Woynowskie } \\ \text { B. J. Krall } & \text { E. A. Zeighami } \\ & \end{array}$

Technical Support:

J. F. Allred

S. N. Burman

R. L. Coleman

J. R. Davidson

R. C. Gosslee

M. K. Jensen

R. R. Knott

C. R. Lambert

R. P. Lenc

R. A. Mathis

V. P. Patania

G. A. Pierce

E. M. Pilz

D. E. Rice

D. A. Roberts

D. A. Rose 
T. R. Stewart

P. F. Tiner
J. E. Wilson

W. Winton

Administrative Support:

L. K. Ailey

D. K. Barslund

T. L. Bradford ${ }^{1}$

A. W. Brown ${ }^{1}$

L. E. Collins

N. F. Delene ${ }^{3}$

D. F. Dickerson

T. J. Graves

Guest Scientists:

L. L. Cole

E. C. Lisic

Consultants:

A. Babich

D. Barth

T. A. Burke

M. M. Carrabba

M. F. Catania

J. A. Cherry

M. R. English

C. Glore

M. M. Goodman

R. Johnson

P. G. Kale

M. Marcus

M. Miller

\section{Students:}

J. A. Bacon

B. C. Bauer

S. L. Blevins

R. L. Clemons

F. G. Dolislager

M. W. Enghauser

R. R. Fuller

D. D. Goff

T. E. Huston

K. M. Jahn

C. M. Johnson
L. $\mathrm{Hamm}^{3}$

S. E. Huckaba

O. V. Jennings ${ }^{1}$

C. D. Retolaza

S. G. Rogers

G. G. Shearin

L. H. White ${ }^{1}$
A. Moreno
R. A. Zingaro

J. A. McIntrie

M. Ozbilgin

G. Paulson

J. W. Posston

A. D. Sauter

J. Solyst

T. Spittler

M. G. Stabin

J. Stubbs

S. R. Sturm

P. K. TerKonda

W. F. Whicker

L. R. Williams

W. I. Kaechele

S. S. Kilgore

S. J. Lambert

A. T. LaSirena

H. G. Lawson

E. Y. Lee

S. M. Lee

S. M. Lewis

M. A. Lindsey

K. L. Marshall

D. F. McDuffie 

L. D. McGinn
D. D. McKinney
C. N. Millsaps
L. M. Mishu
A. K. Moore
B. J. Moore

\author{
R. A. O'Connor \\ D. R. Purdy \\ S. S. Todd \\ J. J. Walls \\ F. L. Wang \\ J. C. Wright
}

Subcontractors:
J. P. Abston
T. M. Allen
M. F. Amer
C. D. Ashe
R. D. Bagley
K. G. Bell
S. M. Berkoff
W. H. Burke
A. C. Butler
S. L. Campbell
F. I. Case
G. N. Case
G. H. Cofer
N. L. Conklin
D. J. Corona
H. L. Dennis
J. C. DePriest
P. V. Egidi
D. B. Ertel
R. E. Faw
S. M. Field
D. S. Foster
W. L. Foutz
C. C. Francis
L. L. Friese
C. L. Gist
D. A. Gibson
C. Griffith
K. A. Hebbard
T. D. Herrera
R. F. Hughes
A. R. Jones
A. K. Klitz
L. R. Lesperance
N. F. Lewis
D. S. List
D. A. Locke

J. M. Lovegrove

D. C. Marty

R. L. Meredith

M. E. Mumby

G. D. Overton

A. T. Payne

J. L. Payne

R. G. Phillips

S. E. Potter

C. E. Ramsey

J. R. Rau

J. A. Rice

E. K. Roemer

P. D. Roundtree

M. E. Ruth

R. J. Saultz

E. P. Schlauger

R. M. Schlosser

D. L. Sellers

B. A. Shaffer

W. H. Shinpaugh

W. L. Sims

S. M. Smith

J. M. Springer

G. K. Stowe

S. B. Swartz

S. H. Tidwell

S. A. Tighe

H. A. Tochtrop

J. Wade

M. E. Ward

A. L. Weber

R. J. Watson

S. M. Welch

L. West

J. L. Zutman

Postdoctoral Fellow:

A. Hasan 
Loanees from other divisions:

E. G. Bailiff 4

L. B. Holland 4

P. M. Kearl ${ }^{5}$

N. E. Korte 5

A. D. Laase 5

F. E. Muggridge 4
W. L. Robbins 6

J. C. Ryman 7

A. L. Sjoreen?

R. C. Ward ${ }^{7}$

${ }^{1}$ Leave of absence.

2Part-time einployee.

${ }^{3}$ Human Resources Division.

${ }^{4}$ Research Reactors Division.

${ }^{5}$ Environmental Sciences Division.

${ }^{6}$ Instrumentation and Controls Division.

${ }^{7}$ Computing and Telecommunications Division.

Research, development, and operational applications activities in the Assessment Technology Section have all expanded during this reporting period due to program growth and the addition of two groups formerly in the Health Studies Section. True to its mission, the section is focused on the development and application of advanced technologies to identify and quantify parameters of demonstrated importance in assessing human health. The capabilities and accomplishments of the section's six groups span a broad range, from radiological and chemical surveys of federal facilities, development of new survey methodologies, and development of advanced photonics for environmental measurements, to measurement and calibration of instrumentation and dosimeters in radiation detection, development of radiation exposure-dose relationships, and design and development of radiopharmaceuticals and radionuclide generator systems for use in disease diagnosis and therapy.

Radiological and chemical surveys are conducted by the Oak Ridge-based Measurement Applications and Development Group and the Grand Junction-based Pollutant Assessments Group. Surveys are conducted for numerous programs and sponsors, for a variety of purpeses (e.g., characterization surveys to establish a need for remedial action, follow-up surveys to verify success of remediation, and methodology development and application to support facility performance assessments). Research and development in this area sas improved in situ measurement capabilities in the field and 
seeks to replace expensive time-consuming labor atory analyses with quick less-expensive field measurements.

The Measurement Systems Research Group also is providing advanced field monitoring devices and capabilities. Research and development efforts of this group have produced in situ chemical pollutant measurement capabilities using fiberoptic devices and rew radiological monitoring and screening tools for field measurement of actinides, transuranics, radon, and in situ measurements of alpha and weak beta radiation. Applied activities of the group include field monitoring for solvents and fuel contamination and renewed interest in indoor air quality, with particular growth in programs for radon assessment and mitigation.

The focus of the Dosimetry Applications Research (DOSAR) Group continues to be improved quantification of radiation dose. Facility resources of this group changed significantly because operation of the Health Physics Research Reactor (HPRR) was permanently discontinued while the Radiation Calibration Laboratory (RADCAL) became fully functional. RADCAL is proceeding toward full certification by the National Institute of Standards and Technology as a secondary standards calibration laboratory. This facility is currently being used by Energy Systems organizations for research, dosimetry calibration, and instrument development and calibration. The facility soon will be available to outside users. The DOSAR staff continues to conduct numerous dosimetry activities including the internationally recognized and heavily participated Personnel Dosimetry Intercomparison Studies.

Research efforts of the Metabolism and Dosimetry Research Group continue to be directed toward the development of radiation exposure-dose relationships. A particular focus of the group is its development of anatomic and biokinetic models to appropriately describe the age-specific nature of exposure-dose relationships. The work of this group continues to be cornerstones for radiation protection guidance documents of the National Council on Radiation Protection and Measurements (NCRP), the Medical Internal Radiation Dose (MIRD) Committee of the Society of Nuclear Medicine, and the International Commission on Radiological Protection (ICRP). The work of this group is also fundamental to the evaluation of diagnostic and therapeutic procedures involving radiopharmaceuticals and machine-produced radiation. At this point, the work of the Metabolism and Dosimetry Group interfaces with that of the Nuclear Medicine Group.

The Nuclear Medicine Group specializes in the design and development of new tissue-specific radiopharmaceuticals for diagnostic and therapeutic applications in nuclear medicine. Specific research activities of the group include radiopharmaceutical synthesis 
and testing, biochemical determination of mechanisms of radiolabeled agent uptake and retention, and preparation and development of processing techniques for radionuclides and radionuclide generators. The restart of the Oak Ridge National Laboratory (ORNL) High Flux Isotope Reactor (HFIR) in June 1990, restored a major resource for this group. Collaborative development and clinical testing of radiopharmaceuticals developed by this group continue to benefit from more than 20 Medical Cooperative Programs at clinics, universities, and other research institutions in the United States and abroad.

Education, training, and university interactions are integral components of the technology transfer process in this section. Also there have been a number of patent applications and invention disclosures.

\section{MEASUREMENT APPLICATIONS AND DEVELOPMENT}

The primary activities of the Measurement Applications and Development (MAD) Group are aimed at detecting radiological and chemical pollutants in the environment and assessing the impacts of these pollutants on the health and safety of exposed individuals. In support of these objectives, the group performs three major activities: (1) identifying potential locations of environmental pollutants; (2) characterizing radiological or chemical pollutants with regard to location, type, and concentration; and (3) conducting research and development of instruments and techniques to advance survey and assessment capabilities. Based on existing expertise and equipment, the MAD Group has the capability of detecting and characterizing any radiological or chemical pollutant of concern to the general public.

Much of the radiological characterization work performed during the reporting period was in support of the Department of Energy (DOE) Formerly Utilized Sites Remedial Action Project (FUSRAP), which is funded through the Office of Environmental Restoration and Waste Management. This work involved surveying and identifying properties requiring remedial action in the vicinity of sites designated by DOE. Funding for this work, which has been almost constant for the past few years, decreased slightly for the review period but should increase during the next period. Comprehensive radiological characterizations were conducted at Painesville, Ohio; Beverly, Massachusetts; Indian Orchard, Massachusetts; Tonawanda, New York; Lodi, New Jersey; Granite City, Illinois; and Pittsburgh, Pennsylvania. Preliminary surveys were conducted at New Kensington, Pennsylvania; Tonawanda, New York; Maywood, New Jersey; Washington, Pennsylvania; and Springdale, Pennsylvania. In addition, surveys 
to verify remedial action were conducted in Tonawanda, New York, and Lodi, New Jersey. Recent directives from DOE indicate that scoping, characterization, and verification activities in support of the FUSRAP effort will continue for several years.

In addition to the FUSRAP work, major radiological pollutant characterizations were conducted at the Portsmouth Gaseous Diffusion Plant in Portsmouth, Ohio, and at the Y-12 Plant in Oak Ridge, Tennessee. The outdoor areas of the Portsmouth site were completely characterized, and a summary report is being prepared. At Y-12, the group is currently conducting a radiological characterization of all indoor areas, which is scheduled to be completed at the end of FY 1992. Also, radiological characterization surveys in support of the ORNL Environmental Restoration Program were continued throughout the repoiting period with five sites being characterized and summary reports issued. Results of these surveys are being used to identify and prioritize areas requiring remedial action at ORNL.

In addition to the radiological surveys, the group conducted chemical and mixedpollutant characterizations at the $\mathrm{Y}-12$ and $\mathrm{K}-25$ sites in support of corporate environmental restoration programs. This work included field sampling to detect and as cess all types of environmental pollutants, preparation of site-specific sampling procedures and health and safety plans, and evaluation and reporting of measured results. Staff members also coordinated (1) removal of several underground storage tanks at the three Energy Systems sites in Oak Ridge; (2) soil gas sampling for organic pollutants at Y-12; (3) lead characterization at the Central Training Facility at Y-12; and (4) training for hazardous material worker certification.

Other efforts in support of environmental pollutant characterization included preparation of a radiological survey procedures manual for DOE's Office of Environmental Health, evaluation and application of liquid scintillation techniques to analysis of soil samples, development of a comprehensive computerized sample tracking and data management system, and development of surface contamination limits for release of material and buildings. The survey procedures manual is a major effort that will be the basis for all radiological contaminant surveys at DOE contractor and field office facilities. In addition, a bus-size mobile field laboratory was designed, procured, and equipped for radiological surveys. This vehicle provides ORNL with state-of-the-art capabilities for field analysis of samples and characterization of all types of environmental pollutants. The experience and capabilities acquired through the expanding environmental pollutant characterization work will continue to advance methods and instruments used for 
environmental assessments and to support technology transfer through publications, fresentations, and workshops.

\section{POLLUTANT ASSESSMENTS}

The Pollutant Assessments Group (PAG) has three major missions. First, the staff continues to be involved in field surveys for radiological contaminants at a variety of sites. Surveys are conducted to determine the need for remedial action or to verify the success of remedial action. Second, the staff conducts remedial investigation/feasibility studies (RI/FS) or Resource Conservation and Recovery Act (RCRA) field investigations (RFI) at federal facilities contaminated with a variety of chemical pollutants. These projects may include sampling of soil, soil vapors, surface water, groundwater or biota from contaminated areas or wells installed in nearby aquifers. Third, the staff conducts performance assessments of new or proposed DOE waste disposal facilities to estimate the potential environmental transport and human health risk from operation of the facility.

The group has been involved in a variety of projects associated with radiological contamination of the environment. Involvement in the Uranium Mill Tailings Remedial Action (UMTRA) Project is drawing to a conclusion. The PAG's Inclusion Survey Contractor activities have produced over 12,000 property survey reports during the last eight years. The PAG will continue to support UMTRA as the Independent Verification Contractor (IVC) for remedial actions in Grand Junction through FY 1992. The PAG also serves as the IVC for several other remedial action projects including the remedial action of the DOE Grand Junction Projects Office, remedial actions of properties by DOE at the Monticello, Utah, Superfund site under the auspices of the Environmental Protection Agency (EPA) and DOE, and remedial actions at the BORAX V facility at the DOE Idaho National Engineering Laboratory, Idaho Falls, Idaho. The PAG staff also conducted an extensive field survey of the former White Point Nike Missile Base in Southern California using the UltraSonic Ranging and Data System.

The PAG is currently conducting a variety of investigations of chemical contamination at DOE and Department of Defense facilities. The PAG has provided major support for the RCRA program at the DOE/Kansas City Plant operated by Allied-Signal Corporation. PAG staff have also conducted RI/FS or similar projects at Fallon Naval Air Station, Nevada; Reno Air National Guard Base, Nevada; Tucson Air National Guard Base, Arizona; and Paducah Gaseous Diffusion Plant, Kentucky. 
PAG staff are conducting performance assessments of two new disposal facilities at the Savannah River Plant, the Saltstone Disposal Facility, and the E-area vaults, as well as another at the U3ahat facility at the Nevada Test Site. These projects include modeling of environmental transport including groundwater transport, radionuclide decay, and foodchain transport, to forecast potential dose to intruders or surrounding populations. A major task on the Savannah River Plant project has been the management of teams from INEL and Washington Hanford who are contributing a portion of the modeling.

PAG staff are involved in a variety of research projects to improve field accuracy and precision of in situ measurements. Measurements of natural colloids in groundwater were taken to develop the colloidal borescope, which is designed to provide in situ measurements of groundwater velocity. Such a device can greatly improve the input data used in groundwater transport models. Colloidal measurements were taken at sites in Kansas City, Missouri; Georgetown, South Carolina; Portland, Maine; Oak Ridge, Tennessee; Cape Cod, Massachusetts; Grand Junction, Colorado; and Fallon, Nevada. The staff is also working to develop a correlation between various field measurements and results of sampling and laboratory analysis. The goal is to supplant expensive and slow laboratory analysis with cheaper and quicker field measurements. The PAG staff has also described the geologic condition of the various sites in a variety of reports and publications.

\section{MEASUREMENT SYSTEMS RESEARCH}

Providing new and state-of-the-art field monitoring devices and capabilities is the principal function of the Measurement Systems Research (MSR) Group. In doing this, a balance of basic research and applied field programs is maintained.

Basic research projects are mostly directed at the solution of specific problems. Research and development is conducted that yields innovative fiberoptic, field monitoring devices for in situ measurements. Specific examples include the fiberoptic derivative ultraviolet spectrometer intended for making down-well measurements of trace constituents of hydrocarbon fuels in groundwater at contaminated DOE sites; an advanced prototype is now available. An earlier Laboratory Directors' research project to study surface-enhanced Raman spectrometry (SERS) has branched into two new programs: a DOE-sponsored program to produrs a portable monitor for weapons treaty verification and another program involving electrospectrochemical research under sponsorship of DOE's research development, demonstration, testing and evaluation (RDDT\&E) program, 
in collaboration with EIC, Inc. of Boston, for in situ detection of chlorinated aliphatic solvents in groundwater. We have also initiated a new Raman spectroscope projert with the Robotics \& Process Systems Division for making direct chemical measurements inside waste storage tanks. New fiberoptic techniques are also being exploited to evaluate the spectroscupic properties of highly toxic warfare agents. This program is being sponsored by the U.S. Army Chemical Research, Development, and Engineering Center.

New radiological monitoring and screening tools for site restoration, and decontamination and decommissioning are being promoted. Photoelectron rejecting alpha liquid scintillation spectroscopy (PERALS) is being adapted for ultrahigh sensitivity field measurement of select actinide and transuranic radionuclides in soil, dust, and airborne samples. A modified procedure has allowed radon in water to be measured with a minimum level of detection of $5 \mathrm{pCi} / \mathrm{L}$. PERALS is also playing a major role in studies of surface contamination and airborne resuspension factors at a former Weldon Spring, Missouri, uranium processing plant, which is soon to be demolished and the site returied to the private sector. Based on the MSR group's experience in solid state radiation dosimetry, a program has been started to evaluate integrating alpha-track detectors and exoelectron detectors. These passive devices can make in situ measurements of alpha and weak beta radiation in difficult-to-access locations, as well as verify that decontamination has been completed satisfactorily.

Applied DOE site restoration activities are expanding rapidly. We are developing a close and integrated working relationship with the Measurement Applications and Development Group; together we provide field monitoring services on short notice for Y-12. Site evaluations for solvent and fuel contamination were conducted at formerly utilized sites in Pine Ridge, Buffalo Mountain, and Chestnut Ridge. At Y-12, a major new project is starting involving simultaneous field screening and reference laboratory analyses. Soil samples for the sewer line upgrade are being collected and analyzed for both chemical and radiological contaminants to determine whether these soils qualify as mixed waste.

In addition to projects directed at hazardous waste problems, the MSR group has major programs in indoor air quality research, with an emphasis on indoor radon problems. A goal of DOE-Office of Health and Environmental Research's (OHER) radon program is to identify the 100,000 "hottest" houses in the United States. In order to achieve part of this goal, it is important to understand the mechanisms causing seasonally magnified indoor elevations of radon in hilly karst regions of the southern Appalachians. Clusters of "hot" houses exist in regions where the natural uranium background is not 
particularly high. Large reservoirs of radon-bearing soil gas exist in networks of underground solution cavities. We have shown that houses able to tap these reservoirs at certain times of the year can qualify for the "hottest" category.

The screening phase has been completed at 260 bases under the U.S. Navy's Radon Assessment and Mitigation Program (NAVRAMP). High radon levels in Mechanicsburg, Pennsylvania, Guam, and a children's day care center in Bermuda were confirmed during immediate, follow-on site assessments. The team also carried out temporary mitigation on problem buildings. NAVRAMP is now in the general assessment phase with measurements completed at about $25 \%$ of the 100 bases where prior screening indicated indoor radon exceeded $4 \mathrm{pCi} / \mathrm{L}$. The 1 ie of 400,000 alpha-track, charcoal, and electret type detectors is required for completion of the assessment phase. A new radon assessment program has been started for the U.S. Post Office. The first phase entails assessment of radon inside 34 buildings leased to the General Services Administration by the Post Office. Service is also being rendered to the U.S. Air Force for training in radon diagnostics and mitigation.

A study is being conducted of toxic emissions from high sulfur coal briquettes that are being considered as alternative, domestic cooking fuels in Pakistan. The study is supported by the Agency for Internationai Development. Additives of slaked lime, clay, and oxidant are intended to reduce the emissions of $\mathrm{SO}_{2}$ and smoke to levels that pose health hazards no greater than those posed by the burning of traditional fuels such as wood and dried cow dung.

Other indoor air quality activities involve recent editorship and publication of the American Industrial Hygiene Association's (AIHA) book, The Practitioner's Approach to Indoor Air Quality Investigations, and the organization of committee involvement with Indoor Air '93 in Helsinki, Finland, via AIHA sponsorship.

Since the last progress report, our programs have more than doubled in size and complexity. Our ability to function successfully as a conduit, bringing together HASRD's more basic research groups and the applied field activity groups of the Assessment Technology Section, is requiring ever increasing integration and collaboration across group and section lines.

\section{DOSIMETRY APPLICATIONS RESEARCH}

Dosimetry Applications Research (DOSAR) Group activities are directed toward improving the quantification of the radiation dose received by individuals. Such activities 
are a portion of the Division's mission of assessment of impacts of energy-related technologies on human health. The primary research tool of the DOSAR Group is the Radiation Calibration Laboratory (RADCAL).

RADCAL has been made fully functional. Appropriate safety committees have been satisfied, and a Protocol Document has been prepared and issued. Application for certification by the National Institute of Standards and Technology as a secondary standards calibration laboratory has been filed for one of our gamma sources (it will continue on a source-by-source basis), RADCAL is now being used by DOSAR personnel for research; by Environment, Safety, and Health (ES\&H) personnel for various dosimetry calibration jobs; and by Instrumentation and Controls for instrument development and calibration. Appropriate arrangements with ORNL's Work for Others personnel and DOE have been made that renders RADCAL accessible to outside users.

The Fifteenth and Sixternth Personnel Dosimetry Intercomparison Studies (PDIS 15 and PDIS 16) were conducted using various RADCAL radioisotopic sources. A total of 50 organizations submitted 1,340 dosimeters for PDIS 15 in 1990. A total of 69 organizations submitted 1,847 dosimeters for PDIS 16 in 1991; this was the most comprehensive PDIS ever conducted. The results of these two annual studies provided us with an indication of the current international status (there were a total of 26 non-U.S. participants) of personnel radiation dosimetry.

DOSAR staff members performed in a number of other important dosimetry activities. Several staff members (1) made detailed preparations for conducting the Third Conference on Radiation Protection and Dosimetry in Orlando, Florida, on October 21 24, 1991; (2) assisted ES\&H personnel by implementing a nuclear accident dosimetry system using the ES personnel dosimeter; (3) received an R\&D 100 award for involvement with the development of a new generation TLD reader; and (4) revised ANSI N13.11, the dosimeter performance tesi standard.

\section{METABOLISM AND DOSIMETRY RESEARCH}

The main task of the Metabolism and Dosimetry Research (MDR) Group is to develop information on the radiation exposure-dose relationships through modeling the biokinetics of radionuclides within the body and modeling the deposition of ionizing energy within radiosensitive tissues from these radionuclides and from radiation externally incident upon the body. Such exposure-dose relationships are the cornerstone 
of radiation protection and also serve an important role in the evaluation of medical diagnostic procedures involving use of radiopharmaceuticals and X-ray machines.

Biokinetic models developed in the past to describe the behavior of radioactive elements have been derived on an empirical basis, that is, by fitting simple mathematical expressions to available element-specific retention data for adult humans and laboratory animals. Such mathematical expressions provide some basis for calculating integrated doses from radionuclides but, in general, have no discernible correspondence to the physiological processes actually controlling behavior of the radionurlides in the body. Development of models describing the biokinetics in persons other than a hypothetical young adult male has required a substantial departure from this approach because of the scarcity of element-specific data for special populations.

As far as is practical, the models currently being developed by the MDR group explicitly depict the tissues and physiological processes controlling the movement or retention of radionuclides in the body. The advantages of a physiologically realistic approach are that it allows (1) incorporation of basic physiological information into the model, (2) realistic treatment of decay products formed in the body, (3) meaningful extrapolation of data from laboratory animals to humans, (4) meaningful analogies between an element of interest and physiologically similar elements, and (5) linkage between excretion of a radioactive clement and movement among body tissues and blood. Biokinetic models developed by the group, as well as age-specific dosimetric models, are featured in Publication 56 of the International Commission on Radiological Protection (ICRP), which tabulates data on the organ dose per unit intake for individuals of various ages.

Members of the group are involved in the work of various committees and task groups for the National Council on Radiation Protection and Measurements (NCRP), the Medical Internal Radiation Dose Committee of the Society of Nuclear Medicine, and the ICRP. In addition, the group provides technical support to the work of the Radiation Effects Research Foundation regarding the dosimetry of the A-bomb survivors, and dosimetry expertise to the National Cancer Institute and various other working groups. Of particular relevance to our research interests is the work of Scientific Committee 57 on Internal Emitters of the NCRP and ICRP Committee 2 on Secondary Limits (the task group on Revision of Reference Man, the task group on Age-Dependent Dose per Unit Intake, and the task group on Dose Calculations). The MDR group also provides expert assistance to the local radiological health protection organization to help improve the 
quality of radiological protection provided to contractor employees, guests, and the public.

\section{NUCLEAR MEDICINE}

The Nuclear Medicine Program focuses on the design and development of new tissue-specific radiopharmaceuticals for diagnostic and therapeutic applications in nuclear medicine. This program continues to receive international recognition for the innovative design and development of new radiopharmaceuticals and is funded by three major projects through OHER. While the core program supports general radiopharmaceutical research, two specialized projects support radioisotope research and radionuclide generator development and research on radiolabeled nucleoside analogues.

In addition to the synthesis and testing of new radiopharmaceuticals for in vivo nuclear imaging and therapeutic applications, research also encompasses biochemical studies to determine the mechanism of tissue uptake and retention of the radiolabeled agents in laboratory animals and in vitro systems. Another major area of research is the development of new radiolabeling techniques for incorporation of radionuclides into tissue-specific agents, and new methods have been developed for radioiodination of molecules sensitive to the usual methods used for introduction of radioiodine. As an example of new tissue-specific agents for diagnosis, several receptor-specific antagonists have been designed, synthesized, and tested in animal models. Since changes in receptor populations have been implicated in many neurological diseases, these new agents hold promise for noninvasive in vivo imaging of cerebral serotonin and dopamine receptors.

The preparation and development of processing techniques of radionuclides and radionuclide generator research is also an important area of research that complements the development of new radiopharmaceuticals. The HFIR again became a major resource for this program since its restart for routine irradiations in June 1990. The procedures developed and incorporated into the Nuclear Medicine Group Procedure Manual are the only procedures at ORNL that have been accepted for target irradiations in the HFIR hydraulic tube positions. In addition to the use of the HFIR for preparation of a variety of radioisotopes used for radionuclide generator research (vide infra) and other reseurch projects, a new, improved electrochemical system has been developed for the facile processing of zinc targets for the production of carrier-free copper-64 and copper-67. In support of this project, the first comprehensive review of production capabilities of U.S. reactors for medical radioisotopes has also been prepared. 
Radionuclide generator research also continues to be a major productive area of research. The development of the first large-scale, clinical prototypes of the tungsten-188/ rhenium-188 generator developed in this project has received widespread recognition, and several new cooperative programs have been established to pursue the use of this radioisotope. Phenium- 188 is a potential replacement for many of the radioisotopes currently used for attachment to tumor-specific antibodies for radioimmunotherapy. The first osmium-194/iridium-194 generator system has been developed in this project, which provides carrier-free iridium-194 as a potential new candidate for radioimmunotherapy and other therapeutic applications.

Another important area of research involves the development of radiolabeled nucleoside analogues for the potential localization and therapy of tumors. Since nucleosides are major constituents of nucleic acids, they are attractive as carriers of radioactive tags to tumor cells because of their increased cell division. A variety of structurally-modified nucleoside analogues have been developed and are in various stages of testing for tumor specificity in various in vitro and in vivo systems. The radioiodinated and fluorine- 18 radiolabeled acyclonucleosides are of particular interest for single photon emission tomography and positron emission tomography, respectively.

Collaboration with external organizations and technology transfer are important activities that bridge the gap between development and testing of new agents developed at ORNL and their use at other institutions. Several invention disclosures and patent applications were filed for new technolugies developed at ORNL and their use at other institutions, as well as the Nuclear Medicine Program. The Medical Cooperative Programs involve joint research projects in conjunction with programs with special expertise for further preclinical testing in both in vivo and in vitro models and for clinical evaluation. Various new agents are evaluated in collaborative programs with over 20 Medical Cooperative Programs at clinics, universities, and other research institutions in the United States and abroad.

Our collaborative studies with these agents in laboratory tumor models show specificity for hypoxic tumors. As a new molecular nuclear medicine initiative, radiolabeled nucleosides are being evaluated to study enzymes related to physiological response of the normal vs. infected (tumor) tissue.

Finally, the clinical testing of new agents, developed in the ORNL Nuclear Medicine Program in conjunction with clinical investigators, illustrates not only the acceptance of our new technology but also the important transition from the laboratory to the clinic. A recent example is the use of a new radioiodinated triglyceride analogue, which has been 
designed, synthesized, and tested in preliminary clinical tests for the evaluation of fat malabsorption resulting from pancreatic insufficiency. The use of this agent, which has been named the "Wurfel test," involves a simple urine analysis, and may be an important improvement over the currently used methods. In addition, the iodine-123-labeled methylbranched fatty acid analogue, BMIPP, developed in the ORNL program for evaluation of cardiac metabolism, is continuing clinical trials at several institutions in the United States and Europe, and is also being used in a 12-center multicenter clinical trial in Japan by Nihon Medi-physics, Inc. A similar ORNL agent, radioiodinated DMIPP, is now commercially available from Cygne, Inc., in Belgium. The balaice between basic research and development at ORNL and interaction with key programs at other institutions continues to form the basis for a strong Nuclear Medicine Program at ORNL. 


\title{
2. BIOLOGICAL AND RADIATION PHYSICS SECTION
}

\author{
R. N. Hamm, Head
}

Staff

Research:
D. P. Allison
E. T. Arakawa
J. C. Ashley
T. A. Callcott ${ }^{1}$
J. G. Carter
L. G. Christophorou
O. H. Crawford
C. E. Easterly
M. W. England
T. L. Ferrell
B. E. Hingerty

D. R. James

T. D. Jones

S. P. McKenzie

L. A. Pinnaduwage

R. H. Ritchie

I. Sauers

J. E. Turner

R. L. Tyndall

R. J. Warmack

A. P. Watson

H. Yoshida

Administrative Support:

J. E. Carrington

S. L. Huling

J. A. Cripps

B. H. Kimmel

D. C. Crowell

B. L. Ramsey

Consultants:

R. E. Alexander

V. E. Anderson

J. S. Bertram

S. R. Broshar

P. C. Gailey

W. A. Garrison
W. Gibson

C. B. Hamilton

G. H. Harman

H, H. Hubbell, Jr.

S. R. Hunter

H. A. Wright

\section{Guest Scientists:}

E. K. Bowman

P. D. Breeden

P. M. Echenique

R. D. Edge

F. Flores

F. J. Garcia de Abajoo

J. P. Goudonnet

S. D. Hamilton

D. L. Hedden

J. K. Hoffmeister

B. Illman

K. S. Ironside

B. H. Khare

E. Lesniewski-Choquet

J. R. Manson

R. K. Matsunami

D. L. McCorkle

J. S. Mittelman 
L. R. Painter

J. M. Pitarke

R. C. Reddick

J. A. Spain

\section{Students:}

P. M. Adam

M. S. Badlani

D. L. Bailey

A. Bitouni

B. C. Bond

D. B. Boyles

R. A. Cacheiro

A. C. Chang

J. Y-C. Chang

G. Chen

E. G. Furlong

J. A. Goetz

A. P. Gove

A. B. Holland

A. Huang

T. E. Huston

R. A. Jernigan

T. J. Kreutz

N. K. Krishna

J. Lawn

E. B. Lee

I. Lee

Postdoctoral Fellows:

P. G. Datskos

H. Faidas

I. Lee

R. C. Reddick

Loanees from other divisions:

K. B. Jacobson ${ }^{2}$
C. C. Sung

P. S. Tuminello

A. A. Vass

W. C. Wilson
A. J. Lourenco

J. A. Luna

C. Meisse

M. Namioka

J. E. Parks

M. Perdereau

R. C. Reddick

L. Salomon

J. P. Sawyer

S. H. Sharp

M. A. Stanley

D. P. Tsai

P. S. Tuminello

S. B. Utter

K. R. Uziel

P. A. Vanderhoff

S. M. Weeresinghe

J. E. Wigton

L. E. Williams

Z. C. Wu

L..Zhou
T. G. Thundat

P. A. Vanderhoff

V. Zabel

X. Zheng

S. McElhaney ${ }^{3}$

1 Part-time employee.

2Biology Division.

${ }^{3}$ Instrumentation and Controls Division. 
Activities within the Biological and Radiation Physics Section consist primarily of basic physics research studies directed toward providing new scientific knowledge about the fundamental properties of matter in all phases (gas, liquid, and solid) and, in particular, of processes and mechanisms important in the interaction of pollutants with biological materials. The section also develops and improves methodologies to assess the impact and risk of various technologies on human health. Both theoretical and experimental studies are included in the section's research activities, which involve stateof-the-art technology in many areas, such as scanning tunneling microscopy, surfaceenhanced Raman scattering, soft X-ray emission spectroscopy, and computer modeling. Some of the research highlights of the past 18 months in each of the five groups in the section are reported below.

The section continues to have significant interactions with many other research institutions, both in the United States and abroad. Eight visiting scientists from foreign institutions, 18 visiting scientists from U.S. institutions, and 43 students worked within the section at various times during this reporting period.

\section{ATOMIC, MOLECULAR, AND HIGH VOLTAGE PHYSICS}

The research program of the Atomic, Molecular, and High Voltage Physics Group is devoted to the study of electron-molecule interactions and negative-ion processes, electron-excited molecule interactions, interphase physics, the electrical properties of the liquid state of matter, and the basic physics of gaseous dielectrics, pulsed power switches, and radiation detectors.

We have developed a method for studying electron attachment to short-lived $\left(<10^{-8} \mathrm{~s}\right)$ electronically-excited states of molecules and have observed the first photoenhanced electron attachment to such states. We have recently observed slow electron attachment to superexcited states (presumed to have lifetimes $\sim 10^{-9} \mathrm{~s}$ ) of tertiary amines and nitric oxide using this technique; these states have an estimated electron attachment cross section over one billion times larger compared with those of the respective ground states.

A new, two-laser photoconductivity technique has been developed that allows measurement of binding energies of electrons to molecules/atoms/radicals in liquids. The technique is currently being developed to allow-in addition-measurements of photodetachment cross sections in liquids. The first results using this new technique have been obtained for $\mathrm{C}_{6} \mathrm{~F}_{6}{ }^{-}$in liquid tetramethylsilane (TMS); they indicate that the photodetachment threshold for $\mathrm{C}_{6} \mathrm{~F}_{6}-$ in TMS $(\mathrm{T}=300 \mathrm{~K})$ is $\sim 1.6 \mathrm{eV}$, and that the 
photodetachment cross section for this anion exhibits maxima due to photoexcitation of the anion. Our work on the systematic study of the electron transport properties of fast dielectric liquids/mixtures provided the most accurate electron drift velocity and electron drift mobility data to date on these systems. Our measurements proved valuable to the development of new media for advanced radiation detectors.

Temperature-enhanced electron detachment from a long-lived (lifetime $\sim 9 \mu \mathrm{s}$ ) negative ion has been observed and quantified. The autodetachment of the long-lived c $-\mathrm{C}_{4} \mathrm{~F}_{6}-$ anion was found to increase profoundly with increasing temperature, $\mathrm{T}$, above ambient, especially above $\sim 450 \mathrm{~K}$. Under the same conditions electron attachment to $\mathrm{c}-\mathrm{C}_{4} \mathrm{~F}_{6}$ was found to decrease with increasing $\mathrm{T}$ above $\sim 450 \mathrm{~K}$. This is the first time that the effect of temperature on both processes (electron detachment and electron attachment) has been established.

The profound effect of vibrational excitation of molecules on electron transport has been demonstrated for the first time. Fast (high electron drift velocity), cool (low electron diffusion), and efficient (high electron yields) detector gases have been identified (e.g., $\left.\mathrm{Ar} / \mathrm{CF}_{4} / \mathrm{CO}_{2}, \mathrm{Ar} / \mathrm{CF}_{4} / \mathrm{H}_{2} \mathrm{O}\right)$ from a knowledge of their electron drift velocities, electron impact ionization, electron attachment, electron scattering, and electronic energy levels.

The first comprehensive review of electron-excited molecule interactions has been completed and was presented as an invited lecture at the 20th International Conference on Ionization Phenomena in Gases, Pisa, Italy, in July 1991. Also, the book Gaseous Dielectrics VI was published in September 1991.

Extensive collaboration has begun with colleagues at the Free University Berlin and the Hahn-Meitner Institute on interphase physics and clusters of electronically excited molecules.

\section{PHYSICS OF SOLIDS AND MACROMOLECULES}

The Physics of Solids and Macromolecules Group concentrates on making basic measurements, by a variety of techniques, of the optical and electronic properties of solids, macromolecules, liquids, and thin films over a wide range of photon energies and temperatures. Other areas of research include resonance ionization spectroscopy, soft $X$ ray emission (SXE) and absorption spectroscopy, photoacoustical measurements, gas decomposition and ion chemistry studies, and measurements and calculation of lowenergy electron mean free paths in solids and macromolecules. Studies in this program 
should lead to a better understanding of biologically interesting materials and biological systems and to development of new low-level pollutant detectors.

With our collaborators at the University of Tennessee (UT) and the National Institute of Standards and Technology (NIST), we have continued our studies of SXE excited by electrons and by X-ray photons from the National Synchrotron Light Source (NSLS). A new monochromator utilizing a variable-line-space reflection grating used in grazing incidence was designed to replace the present transmission grating monochromator and was installed in the summer of 1991. Research was completed and three papers submitted on the transition-metal silicides (Ni, Co, and Fe silicides, implanted $\mathrm{Co}$ and $\mathrm{Fe}$ in $\mathrm{Si}$ ) of interest in semiconductor applications. Papers have also been submitted and accepted on densities of states and localized excitations in light element oxides (MgO, $\mathrm{SiO}_{2}, \mathrm{Al}_{2} \mathrm{O}_{3}$ ) and the high $\mathrm{T}_{\mathrm{c}}$ superconductors. Papers on core excitons in $\mathrm{Al}_{\mathrm{x}} \mathrm{Ga}_{1-x} \mathrm{As}$ and the electronic structure of solid krypton and xenon have been written and are undergoing internal review. Studies of bonding in boron compounds have been completed, and a manuscript is in preparation. Studies continue on the electronic properties of light impurities in organic systems, the electronic properties of high $T_{c}$ superconductors, joint excitation by lasers and the synchrotron light source, and the effects of excitation near threshold. A proposal has been funded by the National Science Foundation through UT to construct a new SXE spectroscopy beamline at the Advanced Light Source at Lawrence Berkeley Laboratory; this beamline will provide 40 times greater excitation intensities than our present NSLS beamline, and will greatly extend the usefulness of this spectroscopic technique.

More than $100 \mathrm{Be}$ films ranging in thickness from tens of $\AA$ to several $\mu \mathrm{m}$ were prepared by thermal evaporation onto glass and Si wafer substrates. Optical constants of $B e$ in the wavelength range $0.4<\lambda<2 \mu \mathrm{m}$ were determined by ellipsometry and from relative reflectance measurements as a function of film thickness, evaporation rate, and other deposition parameters. A major goal of this work was to produce (for space applications) high-quality Be mirrors with large reflectance (> 98\%) in the region $1<\lambda<10 \mu \mathrm{m}$.

Using our laser desorption and ionization/time-of-flight mass spectrometer, we have measured the kinetic energy distributions of atoms and molecules desorbed after surfaceplasmon excitation. For all metals studied, Ag, Al, and $\mathrm{Au}$, a low-energy (0.08 $0.09 \mathrm{eV})$ thermal peak and a high-energy $(0.4-1.0 \mathrm{eV})$ peak attributed to electronic excitation have been observed. Rhodamine $B$ molecules were desorbed by this method 
without fragmentation. The yields of neutral metal atoms were found to agree well with the calculated energy density at the metal-vacuum interface.

Ellipsometry was used to measure the index of refraction of six infrared window materials ( $\mathrm{Si}, \mathrm{Ge}, \mathrm{As}_{2} \mathrm{~S}_{3}, \mathrm{SiO}_{2}, \mathrm{Al}_{2} \mathrm{O}_{3}$, and $\mathrm{ZnSe}$ ) before and after these samples were exposed to nuclear weapons radiation. No change in the index was observed in the irradiated samples, and we concluded that no radiation damage was present. The results of this work will be used to determine the survivability of military weapons systems.

We have combined a soft X-ray grating spectrometer with a scanning electron microscope (SEM) for the mapping of light elements. SEM images have been obtained of $\mathrm{Si}$ and $\mathrm{C}$ in various distributions. Efforts are being made to increase the signal-tobackground ratio in order to increase the sensitivity for lower concentrations.

We have measured the optical properties of epitaxial $\mathrm{CoSi}_{2}$ films on Si from 0.06 to $2.75 \mathrm{eV}$ by ellipsometry and spectrophotometry. The energy dependencies of the dielectric constants show Drude behavior at energies lower than $\sim 0.2 \mathrm{eV}$ with Drude parameters $\hbar \omega=(5.8 \pm 0.2) \mathrm{eV}$ and $\hbar / \tau=(0.09 \pm 0.02) \mathrm{eV}$. Using the measured optical constants, the $\mathrm{CoSi}_{2}$ film is shown to have maximum absorptance at a thickness of $\sim 10 \mathrm{~nm}$ for $\lambda>1.4 \mu \mathrm{m}$. We have also calculated the absorptance of a composite film of $\mathrm{CoSi}_{2}$ particles embedded in $\mathrm{Si}$ and found that the absorptance peak due to a surface plasmon resonance in the $\mathrm{CoSi}_{2}$ particles shifts to lower energy as the ellipsoidal particles become more elongated, in agreement with recent observations.

Two techniques have been developed for the detection of the highly toxic species $\mathrm{S}_{2} \mathrm{~F}_{10}$ (threshold limit value for human exposure, 10 parts-per-billion [ppb]), which is a by-product of electric-discharge-decomposed $\mathrm{SF}_{6}$, a dielectric gas used extensively for high-voltage insulation in compressed gas insulated high-voltage equipment. The first technique developed in collaboration with NIST utilizes gas chromatography-mass spectrometery (GC-MS) in combination with surface catalysis to bring about a detection limit of $4 \mathrm{ppb}$ of $\mathrm{S}_{2} \mathrm{~F}_{10}$ in $\mathrm{SF}_{6}$. The second technique involves the use of cryogenic enrichment coupled to gas chromatography with electron capture detection. Currently this technique has a sensitivity of $75 \mathrm{ppb}$. Its advantage over the GC-MS technique is that it retains its high sensitivity in the presence of $\mathrm{SOF}_{2}$, a major by-product of $\mathrm{SF}_{6}$ spark and high-power arc discharges. Both techniques have been recently used to analyze a sample of arc-decomposed $\mathrm{SF}_{6}$ produced at Ontario-Hydro, a Canadian electric power utility and partner in a Cooperative Research and Development Agreement (CRADA) set up with ORNL and NIS'T to determine whether $S_{2} F_{10}$ is produced in $S_{6}$-filled power equipment. The CRADA is being sponsored by DOE, Electric Power Research Institute, Bonneville 
Power Administration, Tennessee Valley Authority, Canadian Electric Authority, and other electric utility companies. Preliminary investigations indicate that $S_{2} F_{10}$ is produced in power arcs, contrary to previous thoughts by the utility industry. Furthermore, there is evidence that significant concentrations of $\mathrm{S}_{2} \mathrm{~F}_{10}$ (greater than $10 \mathrm{ppb}$ ) exist in cylinder $\mathrm{SF}_{6}$ for some of the cylinders analyzed. These studies were initiated by ORNL, where $\mathrm{S}_{2} \mathrm{~F}_{10}$ was first reported in spark breakdown studies.

A study of the ion chemistry of $\mathrm{SF}_{6}$ corona has been completed; we believe it is the most comprehensive work on the subject to date. From basic studies of sampling positive ions from positive corona and negative ions from negative corona, we have been able to understand processes occurring both in the high-field region of a corona discharge and in the ion-transport region. Results of the work include (1) the first direct evidence of the presence of transient neutral discharge-induced fragments, (2) identification of the negative ion most likely responsible for collisionally-induced electron detachment leading to discharge initiation, and (3) influence of $\mathrm{SF}_{6}$ by-products and water on ion chemistry.

\section{LIQUID AND SUBMICRON PHYSICS}

Research in the Liquid and Submicron Physics Group is devoted to the basic physics of liquids and of submicron structures with allied applications developed as they evolve. Important advances in microscopy, sequencing of the human genome, and detection of ultralow levels of chemical compounds have thereby been marle. Electron scanning tunneling microscopy and atomic force microscopy of isolated DNA molecules has been successfully carried out. This has produced the first images of DNA molecules that contain complete genes (the helical structure is readily apparent in the images). Sequencing of the human genome with simultaneous imaging may thus be practicable, and a major interdisciplinary effort is being carried out with this objective.

The group has also invented a new type of microscope: the photon scanning tunneling microscope (PSTM). A patent has been granted on the PSTM, and commercial production will be realized within the next year by a combined French and U.S. industrial elfort. The group is currently adding spectroscopic capabilities to the PSTM to develop a new chemical-mapping instrument for biological and environmental purposes. This instrument produces data at subwavelength resolution on insulators and yields a threedimensional topographical map that can be directly processed by computer.

Surface-enhanced Raman scattering (SERS) has been studied, used, and improved by the group in collaboration with other groups. One goal of this work is to produce 
submicron structures of high signal enhancement capability in order to reduce the cost and size of the instrumentation. A highly useful, field-portable, chemical-screening instrument based on SERS would permit unambiguous detection of pollutants and toxic compounds at remote sites. The microstructures are vital to attaining this capability and have been improved using microlithographic methods.

\section{ANALYTIC DOSIMETRY AND SURFACE PHYSICS}

The Analytic Dosimetry and Surface Physics Group undertakes basic studies of the interictions of radiation with matter, both for understanding the fundamental physics involved and for application to dosimetry, instrumentation, and modeling of the chemical and biological effects of radiation. Particular emphasis is given to matter in the condensed phase and to surface physics phenomena. In addition, the group conducts strong collaborative studies with the Biology Division on molecular mechanisms of radiation damage to biological systems.

A number of studies were completed or substantially advanced. The theory of surface plasmon-mediated ion emission from laser-bombarded surfaces was developed and evaluated to compare with data obtained by experimenters in HASRD. Good agreement was found. The first complete theory of energy loss by a proton moving in a solid, valid at all proton energies, has been developed; excellent agreement with all available experimental measurements is found. The Manson-Ritchie self-energy formalism was employed to determine the quantal image potential for an electron near an impenetrable surface. This is the first theoretical treatment of this problem in which a Coulombic basis set was employed. Review papers were written on "Electron Spectra in Solids" and on "Radiation Interactions and Energy Transport in the Condensed Phase." The binding energy of a hydrated electron in the vicinity of a water cluster was evaluated theoretically. A new theoretical formulation of the $Z^{3}$ effect in the stopping of ions in matter was given and is being evaluated numerically. A new approach to the theory of radiative capture of electrons by swift, channeled ions in solids has been made that shows good agreement with data obtained by workers in the Physics Division at ORNL. A model was developed and used to calculate positron or proton energy-loss rates and inelastic mean-free paths in condensed media from a knowledge of their optical properties. Studies continued on the reported occurrence of nuclear fusion from accelerated $\left(\mathrm{D}_{2} \mathrm{O}\right)_{n}{ }^{+}$clusters on deuterated solids. It was shown that redistribution of energy in sequences of binary collisions does not account for measured yields. Research 
applying density functional theory to the study of low-velocity atoms in an electron gas was initiated.

Computer modeling of DNA structures for the Human Genome Initiative has continued. In collaboration with the Engineering Physics and Mathematics Division, the use of massively parallel computer architectures for the study of DNA structure has been initiated. Several DNA models that agree with Nuclear Overhauser Effect data from Nuclear Magnetic Resonance have been published. The Structural Biology Initiative is being pursued in relation to biological instrumentation for the High Flux Isotope Reactor in preparation for the Advanced Neutron Source. This will complement our X-ray studies of macromolecular structures. In other collaborative work with biologists, studies continued on the effects of different metal ions on the hybridization of oligonucleotides. In addition, work was initiated to measure radiation products from DNA structures by using Fourier transform mass spectrometry.

In applied health physics areas, a study of skin dosimetry for beta particles was completed. Also, a computer code was written to simulate alpha-particle irradiations of tissue in experiments carried out in the Biology Division.

\section{HEALTH EFFECTS}

To improve human health risk assessments, the Health Effects Group generates and synthesizes laboratory-based bioassay data, analyzes epidemiology studies, and develops mathematical models based on first principles. Work is intentionally balanced between studies at a fundamental level and applications. Long-term objectives include the placement of hazards from varying insults (e.g., chemicals, nonionizing electromagnetic energy, physical agents, ionizing radiation, biological hazards) on a common scale and the development of methods to place the common scale of hazards in perspective with consequences of normal daily human life. This report summarizes three of many activities performed during the reporting period.

In the past year we have cooperated with the Cetus Corporation, Knoxville, Tennessee, in field testing their polymerase chain reaction assay for Legionella. Results indicate a greater presence of environmental Legionella populations than would be detected by the more limited testing available using direct fluorescent antibody test. Also we have defined the bacterial population of the amoebic/bacterial consortium 46 and investigated some potentially marketable properties of the bacteria. The consortium per se can degrade trichloroethylene. Sixteen different bacteria are present in the consortium. 
Most of the bacteria are nonfermenters. One isolate produces a broad spectrum antibiotic. Several isolates produce dispersants, several produce crystals, and one isolate can degrade or alter trinitrotoluene. Thus, the consortium and its components are of both theoretical and pragmatic interest.

A mathematical model for damage, repair, killing, and repopulation of myelopoletic marrow has been described and compared with experimental studies on stroma cell vs. hematopoletic stem cell (HSC) interactions. The calculations have found repopulation of cell lineages deriving from the HSCs to be controlled totally by stroma cell survival. Various therapeutic protocols can be compared with the model, which has been developed thus far using mouse data.

Typical radiation therapy protocols call for radiation schedules from one to three times per week; however, some twice-per-day irradiations are also practiced on five-day schedules. Because of cell population dynamics, at two weeks into therapy and beyond, there may be an order of magnitude or greater difference in the percent of bone marrow function, depending on the protocol chosen. These results asupport the argument for extension of model development to humans in support of medical applications, space exploration, and Department of Defense strategies.

The Reentry Technical Support Activity at ORNL is a multidisciplinary research and assessment task of the Army-sponsored Chemical Stockpile Emergency Preparedness Program (CSEPP). The goal of this activity is to develop decision criteria necessary to guide controlled (e.g., monitoring teams) and uncontrolled (e.g., unlimited public access) reentry to off post, agent-contaminated areas in the event of a release during storage or disposal of the nation's aging stockpile of unitary chemical munitions. In support of health impacts evaluations and planning strategies, research staff of three divisions (Analytical Chemistry, Environmental Sciences, and Health and Safety Research) are currently involved in this effort under our direction. Current issues being addressed include: biomonitoring; low-level detection of agent simulant spikes in crops, foodstuffs, and building materials; and simulant permeability of commercial protective clothing materials. Since November 1990, this work has generated two open-literature publications, one TM report, four papers submitted for journal publication, two white papers for the Office of the Assistant Secretary of the Army, and three manuscripts proceeding through ORNL review. Numerous presentations have been given by the principal investigators and the Task Leader, and several briefings have been provided to military officers. 
We also provide technical support to the Reentry/Restoration Subcommittee of the CSEPP Steering Committee. Current activities include preparation of a Reentry/Restoration Plan "shell" for use in future exercises or any incidents of agent release. This tool, when completed, will provide decision priorities, checklists, compilations of available resources, etc., to working groups dealing with reentry issues during the heat of an exercise or incident. 


\title{
3. CHEMICAL PHYSICS SECTION
}

\author{
J. C. Miller, Head
}

\section{Staff}

Research:
S. L. Allman
H. S. Carman, Jr.
C. H. Chen
$\mathrm{R}, \mathrm{N}$, Compton
W. R. Garrett
G. D. Griffin

J. P. Judish

C. E. Klots

M. G. Payne

M. Uziel

T. Vo-Dinh

Technical Support:

G. H, Miller

R. C. Phillips

Administrative Support:
J. B. Cooper
D. C. Crowell
N. S. Currence
D. G. Henderson ${ }^{1}$
D. Holt

Consultants:

D. Charalambidis

W. Christian

K. D. Cook

C. S. Feigerle

C. Fotakis

R. F. Haglund, Jr.

J. R. Haigis

D. A. Harkins

G. S. Hurst

H. B. Kinser

P. Lambropoulos

M. P. McCann

P. W. Morrison, Jr.

M. Panjehpour

J. E. Parks

P. J. Phillips

R. D. Piccard

M. S. Pindzola

H. P. Saha

M. J. Sepaniak

A. Tuinmann

P. M. Viallet

P. Williams

Guest Scientists:

V. Ananthanarayanan

W. F. Frey

C. S. Fuhrer

H. B. Kinser 
Y. S. LI

G. Lyon

J. S. Nall

T. Pal

A. A. Puretzky

Students:

D. P. Armstrong

E. Arnold

S. J. Bajic

J, R, Bowyer

W. D. Brandon

L. E. Cuellar

B. A. DiCamillo

J. J. DiCillo

I. Datskou

S. R. Desai

J. Dominguez

E. L. Furlong

M. L. Godwin

Postdoctoral Fellows:

D. Ding

A. K. Pal

L. Ramirez

Subcontractors:

J. P. Alarie

M. R. Baker

Loanees from other divisions:

H. A. Barnette 2

1 Dual capacity.

2Instrumentation and Controls Division.
A. Stone

S. A. Taylor

B. R. Thomas

D. L. Venter's
R. C. Hart

A. M. Hemenstine

Y. H. Kim

A. Moore

B. Newby

A. Ononye

K. L. Patterson

M. J. Shea

D. L. Stokes

W. E. Watts

J. E. Wray

K. Tang

C. L. Stevenson

W. S. Sutherland

K. S. Houck

M. D. Pawel

N. Ericson 2 
Activities within the Chemical Physics Section are diverse and interdisciplinary, spanning the fields of physics, chemical physics and physical chemistry, and biochemistry. Complementary theoretical and experimental approaches are directed toward important problems of fundamental science as well as to national needs of an applied or developmental nature.

Studies are being conducted of basic chemical and physical processes relevant to radiological and chemical pollutants and their interactions with other chemical and biological species. Among these are investigations of photoexcitation and photolonization proccsses, molecular clustering phenomena, ion-molecule reactions, biochemical processe, and studies of chemical kinetics in gas- and liquid-phase systems. These studies are related to problems of atmospheric chemistry and physics, pollutant characterization and c'etection, and radiation chemistry and biology. Lasers are used extensively in studies involving multiphoton excitation and ionization, laser fluorescence, surface-enhanced Raman spectroscopy (SERS) and resonance ionization spectroscopy (RIS) of atorns, molecules, clusters, and species absorbed on surfaces. Major portions of these studies are aimed at development of new principles for advanced analytical instrumentation for very low-level environmental pollutant detection. Lasers, fiberoptics, mass spectrometers, and chemical or biological sensors are the building blocks of these novel instruments.

The following brief summaries of activities in the Molecular Physics, Photophysics, and Advanced Monitoring Development groups provide general information on the accomplishments in the Chemical Physics Program for the period April 1990 through October 1991. More detailed information on all of the research can be found in the openliterature references at the end of this report.

\section{MOLECULAR PHYSICS}

The Molecular Physics Group is engaged in experimental and theoretical research in science at the interface between physics and chemistry. Experimental studies involve the use of sonic nozzle expansions together with laser ablation in order to produce ultracold molecules and molecular clusters. Of particular interest is the production of carbon cluster fullerenes $\left(\mathrm{C}_{60}, \mathrm{C}_{70}, \mathrm{C}_{84}, \mathrm{C}_{120}\right.$, etc. $)$. These ultracold gas phase clusters are then studied using laser, charged particle, and excited neutral beams. A strong motivation in these studies is to simulate condensed matter phenomena (solids and liquids) in the "gas 
phase" using large molecular clusters. In such studies one can observe the evolution of a single molecule to the condensed phase. Very fast radiation-induced processes in molecular clusters, liquids, and surfaces are probed with picosecond laser techniques. These studies are guided by theoretical investigations of stabilities and reaction dynamics of the evolving clusters.

A strong component of the program involves the study of nonlinear optical phenomena. This research has led to new ways of generating vacuum ultraviolet and infrared radiation. The Molecular Physics Group was responsible for the development of multiphoton ionization photoelectron spectroscopy. In the course of these studies, we discovered a now well studied cancellation effect in multiphoton absorption. A major part of this research is directed toward the development of advanced instrumentation for health and environmental applications.

Laser ablation of surfaces has become a central focal point in the past two years. Significant progress in the basic understanding of laser ablation has occurred as a result of the development of new experimental techniques in the group. Experiments have shown that the decay of surface plasmons in roughened silver induced by laser radiation gives rise to fast $\mathrm{Ag}^{+}$ions. In addition, the use of laser ablation has allowed for the creation of new materials, such as the fullerenes $\mathrm{C}_{60}, \mathrm{C}_{70}, \mathrm{C}_{84}$, etc., and their derivatives $\mathrm{C}_{60} \mathrm{~F}_{48}$, $\mathrm{C}_{60} \mathrm{O}$, etc. Collaborations with the Analytical Chemistry Division and the University of Tennessee (UT) as well as theoretical contributions have shown that the doubly charged anion of $\mathrm{C}_{60}$ and $\mathrm{C}_{70}$ exists and may be stable. Separate studies with collaborations from the Arizona State University have shown that linear $C_{n}=(n=7-32)$ ions also exist. A review article on multiply charged negative ions has been completed.

The enormous impact that laser ablation studies are having in chemical physics was emphasized at a recent DOE-sponsored workshop hosted by the Chemical Physics Section. Papers presented at the workshop are available as a published proceedings.

Photoionization of an atom represents one of the most elementary collision processes. The use of high-powered lasers has allowed the group to pioneer many of the new methods of studying single and multiphoton ionization of atoms. During the past year, the first measurements of the effect of circular dichroism on a photoelectron angular distribution were reported. The effect of hyperfine coupling w'as demonstrated for the $7 \mathrm{P}_{3 / 2}$ and $8 \mathrm{P}_{3 / 2}$ states of the cesium atom. Together with theoretical contributions from the University of Southern California, a study of multiphoton ionization of xenon and krypton was published in which measured photoelectron angular distributions and branching ratios were compared with theory. In separate studies, ultrahigh resolution 
tunable diode lasers have been used in experimental studies of atomic and molecular beams. With the help of a visiting scientist, photoionization of the hyperfine resolved $5 P_{1 / 2,3 / 2}$ excited states in an atomic beam has been studied. The Doppler motion is suppressed by exciting at right angles to the beam. The development of this new capability will allow a variety of new experiments in both the areas of photoionization and collisions.

The study of multiphoton ionization (MPI) of complex molecules has revealed a number of surprises. Using rather modest power densities $\left(\sim 10^{10} \mathrm{~W} / \mathrm{cm}^{2}\right)$ from a pulsed Nd:YAG laser, multiply charged uranium ions (up to $U^{4+}$ ) have been observed from MPI of $U_{6}$. For some wavelengths, the ions observed (e.g., $\left.U^{3+}\right)$ require the absorption of up to 100 photons. The possible mechanisms for this rather striking result are being considered (e.g., collective excitation, nuclear excitation by electronic transitions, etc.). In a separate study, the mass spectra, photoelectron, and ion kinetic energy distributions resulting from MPI of osmium tetroxide have been obtained. As in the case of $\mathrm{UF}_{6}$, high order MPI is responsible for the production of $\mathrm{Os}^{+}, \mathrm{Os}^{++}, \mathrm{O}^{+}$, and $\mathrm{OsO}^{+}$ions.

\section{PHOTOPHYSICS}

Major efforts in this reporting period fall into five broad categories: (1) DNA sequencing by laser and mass spectrometry; (2) invention of freon detectors; (3) studies of nonlinear optical phenomena and molecular resonance ionization spectroscopy; (4) kinetics of irradiated materials; and (5) high $T_{c}$ superconductors. Each of these is described in detailed below.

A facility that combines laser desorption, laser ionization, and mass spectrometry has been under construction. This facility is intended to be used for DNA sequencing with much faster speed than gel electrophoresis.

Two freon leak detectors were invented, and applications for U.S. patents have been filed. One leak detector is based on electron capture of freon molecules to reduce the gain of a proportional counter. Detection sensitivity better than $0.5 \mathrm{oz}$ per year was demonstrated. This is a simple hand-held detector that can detect not only CFC (chlorofluorocarbon) but also FC and HFC, such as R-134A. The other invention is intended to distinguish between different freons in freon mixtures.

We have continued our detailed studies of fundamental processes that affect RIS, including nonlinear processes that can strongly affect resonant multiphoton excitations of atoms and molecular systems. We found that photon fields generated within the sample 
can greatly modify the atomic response to an incident laser field, resulting in reductions in expected resonant excitation and/or emission rate or in a strong shifting of resonant line positions at elevated pressures. Detailed experimental and theoretical studies have provided substantial understanding of a number of these cases.

A mass spectrometer was constructed and used to measure spectra of ions and neutral components desorbed and/or ablated from superconductors, metals, and fish scales. The information generated is valuable not only for determining the components of the target samples, but also for understanding the mechanism of desorption processes.

A new facility equipped with the capability of Fourier transform infrared (FTIR) spectroscopy, mass spectroscopy, emission spectroscopy, absorption spectroscopy, temperature-controlled substrates, and pulsed molecular beams was built. It can be used to monitor all gas species during the laser ablation process, as well as surface conditions.

\section{ADVANCED MONITORING DEVELOPMENT}

The research program of the Advanced Monitoring Development (AMD) Group is aimed at developing novel and unique monitoring technologies to measure (1) chemical pollutants, (2) related biological indicators of environmental exposure, and (3) human health effects associated with energy-related technology development. The research approach of the AMD group involves multidisciplinary research efforts targeted in three major areas: (1) cost-effective chemical and biological screening techniques; (2) biological and chemical sensors; and (3) basic technical advances of emerging monitoring technologies.

To selectively detect pollutants with specific chemical groups, such as nitro-PAHs, new spectrochemical detection methods were developed. A novel technique developed in the AMD group over the last five years is SERS. The SERS technique can enhance the Raman signal of chemicals up to factors of $10^{7}$ when the se chemicals are adsorbed on SERS-active substrates. The SERS continuous monitor technology developed in the AMD group was recently licensed to Gamma-Metrics, Inc., a California-based company, through the technology transfer effort of DOE and Energy Systems.

Fiberoptic technology in the AMD Group has recently been applied to global atmospheric concerns such as the ozone depletion problem. In collaboration with research staff from the Environmental Sciences Division and the Instrumentation and Controls Division, AMD research staff members have developed a fiberoptic microprobe capable of measuring profiles of ultraviolet (UV-B) light within plant leaves in order to 
assess the effect of increased levels of UV-B radiation on terrestrial plant life. UV-B radiation, which has increased because of ozone depletion, could cause adverse ecological effects for this and future generations. The UV-B microprobe system integrates state-ofthe-art fiberoptic sensors, submicron piezoelectric micropositioning technology, and a sensitive real-time microchannel detection technique. The UV-B light intensity profile can be measured by the fiberoptic microprobe inserted into leaves exposed to UV-B radiation.

An area of increasing importance to the AMD group's mission is the application of advanced detection techniques to "biological monitoring" of environmental and human exposure to chemicals. This is a challenging area for research and development, and advances in chemical detection methodologies and instrumentation are critically needed to analyze complex biochemical systems in the attempt not only to monitor the presence of chemicals in the environment, but also to assess the ultimate human health effects associated with chemical exposure. As sophisticated chemical detection technologies have evolved over the years, AMD research staff have applied, improved, or developed techniques for the measurement of "biomarkers" of chemical exposure and health effects.

Recent research activities have involved the following areas: (1) continuing studies, funded by DOE, on the toxicity of by-products of electrical decomposition of $\mathrm{SF}_{6}$; (2) development of a highly sensitive photon detector/fiberoptic device for detecting and quantifying luminescent bacteria in mixed bacterial populations in a bioreactor, funded by ORNL Director's R\&D funds; (3) development of a biological test system and suitable magnetic field exposure apparatus to evaluate the effects of extremely low frequency magnetic fields on biological membranes, funded by an ORNL exploratory studies grant; and (4) initial studies to develop a cell culture system to detect carcinogenic promotional efficacy of chemicals and radiation.

Another significant advance in detection of DNA-adducts was made by synthesis of a reporter group that selectively binds to a chemical group that is part of the chernical moiety of the DNA-adduct. This now permits direct measurement of nonfluorescent DNA adducts on intact DNA. The method is complementary to antibody detection.

Fiberoptic antibody-based fluoroimmunosensors (FISs) have also been developed through collaboration between the AMD group and UT. Monoclonal antibodies produced against the BaP-derived DNA-adduct are immobilized at the terminus of a fiberoptics probe or contained in a microsensing cavity within the FIS for use both in in vitro and invivo fluorescence assays. High sensitivity is provided by laser excitation and optical detection. The FIS device utilizes the back-scattering light emitted at the remote sensor probe. A single fiber is used to transmit the excitation radiation into the sample and 
collect the fluorescence emission from the antigen. The laser radiation reaches the sensor probe and excites the BaP bound to the antibodies immobilized at the fiberoptics probe. The excellent sensitivity of this device illustrates that it has considerable potential to perform trace analyses of chemical and biological samples in complex matrices. Measurements are simple and rapid ( $\sim 12 \mathrm{~min})$, and the technique is applicable to other compounds provided appropriate antibodies are used. Recently, the FIS instrument has successfully been used to detect DNA-adducts in human placenta samples. The placenta samples contained one molecule of adduct of $\mathrm{BaP}$ per $10^{7}$ base pairs. The limit of detection of the FIS for DNA-adducts of BaP is about 14 attomoles $\left(14 \times 10^{-18} \mathrm{~mol}\right)$. 


\title{
4. BIOMEDICAL AND ENVIRONMENTAL INFORMATION ANALYSIS SECTION
}

\author{
Po-Yung Lu, Head
}

\section{Staff}

Research:
W. J. Allen
L. J. Allison
C. B. Bast
H. T. Borges
M. M. Brown ${ }^{1}$
G. M. Caton
S. S. Chang
G. S. Danford
M. W. Daugherty
K. A. Davidson
M. C. Davidson'
A. R. Ehrenshaft
E. L. Etnier ${ }^{1}$
R. A. Faust ${ }^{1}$
L. M. Floyd
A. A. Francis
M. W. Francis
R. M. Gove
R. T. Haas
G. T. Hawkins
C. L. Heckman
L. M. Houlberg
P. S. Hovatter

S. M. Hubner

B. W. Kline

E. B. Lewis

B. K. Mansfield

K. H. Mavournin

I. C. Miller

K. C. Miller

H. B. Morgan'

D. M. Opresko'

P. T. Owen

E. T. Owens ${ }^{1}$

H. A. Pfuderer

R. H. Ross

K. G. Slusher ${ }^{1}$

R. S. Stafford

S. S. Talmage ${ }^{1}$

S. Y. Uppuluri ${ }^{1}$

M. S. Uziel

E. S. Von Halle

J. S. Wassom

B. L. Whitfield

L. A. Wilson

R. A. Young

Technical Support:

J. W. Crutcher

J. O. Mynatt

S. J. Campbell

D. M. Stokes

L. F. Goins

J. H. Swenson

G. E. Groover

J. W. Taylor

N. P. Knox

M. E. Langston

K. A. Weaver

J. M. Wyrick'

Administrative Support:

D. G. Arnwine

W. J. Barnard

B. S. Hayes

T. L. DuArt

G. J. Johnson

S. L. Roberts 
D. B. Stinnett

Consultants:
A. E. Adamson
R. L. Bigbee
J. M. Byrd
S. E. Joy
S. A. Martin
C. D. Cochran
S. Milanez
S. M. Draime
B. K. Flesher
A. A. Richmond
R. E. Gibson
D. D. Hatmaker
J. C. Haufe
G. T. Hawkins
S. L. Hawkins
T. I. Hutcheson
G. G. Santore
C. R. Seiber
D. L. Shockey
J. M. Stockstill
L. F. Williams
L. A. Wilson
L. N. Yust

\section{Students:}
B. A. Broyles
D. K. Casey
C. D. Craven
K. A. Davidson
K. H. Davidson
G. L. Duthey
L. A. Eaton
T. G. Elledge
J. M. Goergen
J. P. Hitch
J. M. Hood
G. F. Jones
S. E. Joy
T. D. King
K. A. Kremin
P. K. Mallory

J. A. Martin

J. T. Martin

M. L. Mathis

E. P. McDonald

B. K. McKinley

D. F. Nagy

C. A. Pach

M. S. Panter

J. P. Poston

S. A. Poston

J. D. Rowe

T. P. Sterchi

S. C. Thompson

T. J. Threlkeld

J. R. Webb

Subcontractors:
G. Benke
A. Colb
K. Cooper
J. Dragun
G. Lambert
K. Menon
P. Mirkes
J. Perkins
R. Purdy
V. Rose
G. Stoner
G. Witz
C. P. Yu

'Part-time employee 
The Biomedical and Environmental Information Analysis (BEJA) Section has been a part of the research and development environment of the Oak Ridge National Laboratory (ORNL) since its inception as the Environmental Information Systems Office in 1971, and has historically maintained its major scientific strength in the area of health and environmental effects of toxic/hazardous materials.

During the past year, BEIA continued work in the development of computerized health effects data bases. Funded by the Environmental Protection Agency (EPA) and the National Institute of Environmental Health Sciences (NIEHS)/National Toxicology Program (NTP), the Environmental Mutagen and Teratogen data bases now contain over 75,000 and 48,000 records, respectively, on approximately 22,000 total chemicals. The Environmental Mutagen Information Center (EMIC) has served as the focal point for the EPA Genetic Toxicology (Gene-Tox) Program. The purpose of the Gene-Tox Program is to conduct a systematic review and validation of genetic toxicology studies to establish a registry of test results for chemicals evaluated in selected short-term bioassays. These resources, along with others, were used by the section staff for preparation of numerous health hazard assessments and review documents in related areas for EPA, the Army, and publication in refereed journals.

A further application of these resources is the development of the computer-searchable Material Safety Data Sheets (MSDS) data base, with over 12,000 records. With support from Energy Systems, this data base has been developed to inform employees at the Energy Systems facilities of toxic/hazardous materials with which they may come in contact at the workplace. It is also used to inform the community of the presence of hazardous substances. This was a critical factor in bringing Energy Systems into compliance with hazard communication regulations for the workplace and the community. The overriding need for high-quality health hazard data was the major factor in deciding to use the resources of the Section rather than the commercially available systems. The work has now expanded to provide MSDS information to the Army, Navy, the Department of Energy (DOE) Toxic Materials Advisory Committee, and the Lawrence Livermore National Laboratory.

Development is continuing on a data base for the EPA Environmental Criteria and Assessment Office/Office of Health and Environmental Assessment. The data base, which has been titled the Chemical Unit Record Estimates (CURE), will contain all riskrelated values used by EPA and will become the central data resource for carrying out EPA risk assessments and the key information source for Health Effects Assessment Summary Tables. 
The Human Genome Management Information System (HGMIS) was initiated in 1989. HGMIS will serve as a primary information source and communication media for DOE's Human Genome Program Tasks, which include publication of a newsletter, special reports, and maintenance of an electronic bulletin board. As a result of its successful work for DOE, the National Institutes of Health's National Center for Human Genome Research has joined DOE in support of HGMIS.

In the energy and envirommental areas, work has continued on development of computerized data bases in support of hazardous waste management, transportation, disposal, and remedial actions. Additionally, the staff has participated in a number of collaborative efforts with other parts of ORNL and Energy Systems organizations in developing an Environmental Surveillance Report Data System, modules for the Tiger Team Tracking System Defense Program, DOE's Safety Performance Measurement System, and the Confined Space Inventory Program.

A relatively new initiative involves computer technology applications-desk top publishing and a personal computer (PC)-based expert system. A total of 14 major environmental laws/reference handbooks are prepared by the section using desktop publication technology. The section is also involved in PC-based expert system software evaluation, application, and training. Thus far, two additional applications in environmental review and compliance have been developed: (1) National Environmental Policy Act (NEPA) Environmental Revlew and Compliance; and (2) internal assessment for compliance on eleven categories of environmental laws, including the Clean Air Act, Clean Water Act, Resources Conservation and Recovery Act (RCRA), Superfund Amendment Reauthorization Act (SARA), etc.

During this period, the University of Tennessee (UT) subcontract arrangement was expanded to include students from the Law School. These second-or third-year students are participating in several ongoing regulatory analysis projects, such as the preparation of Standard Practices and Procedure Manuals for the K-25 Site, verification of implementation of Tiger Team findings, and analysis of DOE Orders for audit requirements. Currently, more than a dozen students are involved with the BEIA projects.

\section{HUMAN GENOME AND TOXICOLOGY}

The Human Genome and Toxicology Group develops and maintains several toxicology data bases and information files that are used when evaluating the toxicological 
hazards of chemicals to humans and other living organisms. In addition to this primary focus, communication resources (newsletters, technical reports, etc.) are also produced that facilitate research and information exchange among scientists, administrators, and health workers. The group's work activities are divided into three major areas: genetic toxicology, human genome, and general toxicology.

In genetic toxicology, work continued on the updating of the EMIC data base and the Gene-Tox data base maintained for EPA. The EMIC file contains information on over 22,000 chemical agents from studies published in over 75,(0) scientific papers. The Gene-Tox data base contains the 3-D structures and peer-reviewed test results for over 4,600 chemicals evaluated in one or more of 23 genotoxicity bioassays. All structures in this file have been assigned to three chemical classification schemes that allow for a quick means of segregating chemicals with common structural characteristics. This feature, coupled with the ability to visually examine the structures of chemicals within a specific class, has proved to be an immensely effective tool for studying the influence of chemical structure on genotoxic activity.

Work in support of the national and international effort to map and sequence the human genome is carried out under the auspices of HGMIS, which was inaugurated in March 1989 to serve as one of the primary information resources for the DOE Human Genome Program. As part of tts work, HGMIS produces a bimonthly newsletter and two technical reports per year for DOE. One of these reports consists of DOE's annual report for the Human Genome Program. The work of HGMIS has provided the DOE Office of Health and Environmental Research with one of its first opportunities to draw attention to its role in the overall effort within the United States to map and sequence the human genome. As a result of its successful work for DOE, the National Center for Human Genome Research at the National Institute of Health has joined DOE in support of HGMIS and publication of the bimonthly newsletter. The first issue of this joint publication, The Human Genome News, was published in May 1990. Through September 30, 1991, nine issues have been published. The newsletter presently has a circulation of over 7,000 and is available to individuals throughout the world.

The other major work effort of the group is devoted to the development and maintenance of the CURE data base for the EPA Environmental Criteria and Assessment Office. The CURE data base provides EPA staff with access to EPA-generated risk assessment data and serves as a research tool for agency scientists. This data base is currently in the Infodata's INQUIRE data base management system at ORNL, and provisions have been made for the transfer of this file to computers at EPA. The design of 
the CURE data base includes speclalized subfiles developed for efficient use of the clata avalable in the EPA documents and special flelds so that the data can be used for modeling and structural activity work. Current!y, 1,900 chemicals are in the chemical file, all of which have been classiffed according to the structural categorles developed by the EPA Gene-Tox Program. This provision now makes it possible to incuire into structural activity of agents tested for genetic toxicology, low-dose toxicology, and carcinogenicity. A PC version of selected information from the manframe CURE file has been developed und is avallable to EPA staff. This PC file will be provided to the regional offices to enable easy access to the complete information on selected chemicals. Design and implementation of an environmental information subfile for the appropriate Information in the EPA documents have begun, and a test file is under review. Plans are being made for CURE to be available within the agency during the next fiscal year.

\section{CHEMICAL HAZARD EVALUATION AND COMMUNICATION}

Federal and state governments are charged by congressional mandate with protecting public health and preserving environmental quality under various environmental regulations, such as the Toxic Substances Control Act, the Clean Air Act, the Safe Drinking Water Act, and Superfund and its amendments (SARA). The staff members of the Chemical Hazard Evaluation and Communication (CHEC) Group have assisted EPA, the Agency for Toxic Substances and Disease Registry (ATSDR), the Army, and the states of New York and Tennessee in developing scientific documents and technical reviews on chemicals potentially subject to these and other regulations. These reports facilitate the decision-making process of establishing permissible toxic levels for chemical regulation. Types of reports include: Toxicological Profiles, Chemical Hazard Information Profiles, Chemical Hazard Assessments, Tier-1 Health Assessment Reports, Water Quality Criteria Documents, Health and Environmental Effects (chronic toxicity and carcinogenicity) Documents, Reference Dose Profiles (oral and inhalation), Reportable Quantity Profiles, Air and Water Quality Standards, Methodology Development for Occupational Health Criteria, and Problem Definition Studies.

In support of the Department of Defense's Installation Restoration Program (IRP) and Energy Systems Envirommental Restoration Program, CHEC staff members are providing

guidance on scientific and regulatory issues and defining cleanup criteria for hazardous waste sites. The Army and Energy Systems have numerous waste sites that must be 
remediated in accordance with applicable EPA policies and guidelines. CHEC scientists are using their knowledge of EPA's regulations and risk assessment strategies to define the necessury criterla for conducting initial hazard assessment. For the U.S. Air Force (USAF), an extensive update and revision of the original three-volume IRP toxicology guide continued. The work involved compilation, analysis, and presentation of similar information on a series of metals, comprising over 80 individual compounds or salts that are of concern to the USAF. This work was completed in June 1991 and is also intended to be included in the on-line data base, which will constitute the fifth volume of the USAF IRP toxicology guide.

With the promulgation of the Hazard Communication Standard by the Occupational Safety and Health Act (OSHA) and SARA, Title III, 14 million workers at more than 320,000 manufacturing facilities as well as private citizens were given the right to obtain chemical safety information about the hazardous chemicals in their surroundings. To assist Energy Systems in complying with the law, CHEC has developed an on-line, interactive retrieval system for MSDS. Data contents of MSDS come from peer-reviewed data bases (HSDB, GENE-TOX, CHEMLINE, RTECS, and TOXLINE) and handbooks, as well as from manufacturers' and distributors' MSDS. The menu-driven system uses the INQUIRE data base management system, which resides on the IBM 3033. The system can be accessed through the time-sharing option on-site and is avallable to all Energy Systems employees and Toxic Material Advisory Committee members of DOE. Currently, the data base contains information on 4000 pure chemiculs and 8000 tradename products. This project has expanded to assist the Army and Navy in implementation of their hazard communication programs.

\section{ENVIRONMENTAL REGULATIONS AND REMEDIATION}

During this period, the Environmental Regulations and Remediation (ERR) Group has expanded its activities in Environmental Compliance for Energy Systems by preparing Standarl Practice Procedures manuals based on environmental regulations and DOE Orders, and by developing an Environmental Surveillance Report Data System.

A valuable resource has been identified and developed with the UT Law School, which selects second- and third-year law students with an interest in environmental law applications to collaborate with BEIA staff on appropriate projects. This has proven to be a useful arrangement, with the students participating in several ongoing projects. They have added a new dimension to the regulatory analysis work. They have supplemented 
the ER.R staff by (1) assisting with the writing of the Standard Practice Procedures manuals for the K-25 Site, a project to verify the completeness of the Tiger Team findings for the Quality Assurance Department of ORNL, (2) assisting with the interpretation of state and federal regulations for the Applicable or Relevant and Appropriate Requirements for DOE and Army sites, and (3) analyzing DOE Orders for review and audit requirements.

Each Energy Systems facility is required to prepare a quarterly report for DOE under the SEN-7A directive. In addition, a monthly accounting of the environmental compliance activities at each fucility is required by the Martin Murietta Board of Directors in Denver. The FRR group is preparing the monthly reports on Environmental Safety and Health compliance activities for ORNL, the Y-12 Plant, and the K-25 Site, as well as the Environmental Restoration Program, the Waste Management Program, and the Board of Directors. These are prepared from PC-based computerized tracking systems developed by BEIA for ORNL, the Y-12 Plant, the K-25 Site, Portsmouth, Paducah, Waste Management, Environmental Restoration, and the Board of Directors.

The ERR group was requested to prepare the Y-12 Tiger Team findings for the Tiger Team Tracking System Defense Program Module for the EG\&C computer system at Idaho Falls, Idaho, and DOE's Safety Performance Measurement System. This was one of two test files selected by DOE for developing the computer system. All time commitments demanded by the Y-12 milestone were met. Work is expected to continue on this system.

A project for the K-25 Industrial Hygiene Department was developed and completed for the Confined Space Inventory Program. A data base was developed to support the information gathered in the survey of over 3000 confined spaces at K-25. The ERR group participated in the survey and developed the data base.

Standard Practice Procedures manuals, based on DOE Orders and Environmental Regulations, are now required of all Energy Systems facilities. The ERR group has prepared a number of these manuals for the K-25 Site's Environmental Management Department. This activity will expand to other fucilities in the coming year. Additional activities included writing and preparing the procedural manual for the Steam Plant of the Utilities Department at ORNL, and an Employee Handbook. These are based on the DOE, Institute of Nuclear Power Operations, OSHA, and other relevant requirements. User manuals and security documentation were developed for the Energy Systems Hazardous Materials Inventory Svstem. 
Development has continued on the Packaging and Transportation Safety (PATS) Program providing support directly to DOE, both for direct information and appraisal report preparation of this DOE-wide project. The PATS data base system was initiated in 1989 to organize information related to DOE packaging and transportation safety activities. It contains specific site information regarding DOE facilities, appraisal visit schedules and reports, appraiser names, training, and expertise. The data base establishes a system for tracking compliance findings, concerns, and corrective actions, if needed. This project provides the DOE Assistant Secretary for Environment, Safety, and Health the information needed to satisfy DOE Order 5480.3.

An Environmental Surveillance Report Data System is being developed for the Health and Safety Environmental Activities Division at the Y-12 Plant. This data system will provide the Division with a mapping system to locate specific environmental data. The environmental data have been organized and prepared; the mapping system is in development.

To support the DOE Short Rota ion Woody Crops Program, data bases for the shortrotation woody crops were developed and expanded to include data from newly planted full-scale field trials and genetic research activities. This activity is a collaborative effor with the Environmental Sciences Division. These data systems and others under development will provide important tools in assessing the energy potential, the cultural management techniques, genetic manipulation, and selective breeding programs for these energy crops that will lessen the U.S. dependence on imported fuels. A new international newsletter, the Energy Crops Forum, has been developed and contains information about the program and other related information.

Regulatory information projects continued to expand as the need for this vital information increased in DOE. The Environmental Safety and Health News (ESHNEWS), a current-awareness weekly publication on issues of environment and safety, continues with new features developed this year. The circulation has steadily increased as the emphasis on rapidly changing information in regulations raised awareness of the implications of responsibility. The Environmental Regulatory Update Table and its companion the Environmental Guidance Program Reference Books on the 14 major federal environmental acts has an increased circulation of over 600) to DOE and Energy Systems managers. 


\section{INFORMATION MANAGEMENT TECHNOLOGY}

Expert systems/computer applications and communication resources were used to respond to needs in many areas from environmental compliance to advanced materials.

A PC-based expert system, NEPA Environmental Review and Compliance, is being developed for the K-25 Environmental Management Department. This expert system, containing the current legislation, will help determine the type of documentation needed to respond to NEPA requirements and to prepare draft categorical exclusion documentation.

Another expert system is being developed for the Health, Safety, Environment and Accountability Division to assist in performing an internal assessment to determine the Y-12 Plant's compliarice with environmental laws. These laws on eleven different categories, including Clean Air Act, Clean Water Act, RCRA, SARA, etc., are mainly federal laws, but also include some DOE Orders and plant standards.

Other applications include an expert system that assists in preparing a QA plan; various tracking systems; an inventory of federally funded Continuous Fiber Ceramic Composite R\&D; and a prototype hypertext system that describes the High Temperature Materials Laboratory user programs, the user laboratories and equipment, etc.

In the communication resources area, desktop publishing techniques have been developed for several applications, including the preparation of newsletters, revision of a Drinking Water Regulations poster, preparation and updating of reference books on legislation, and composition of brochures and questionnaires. The international Ceramic Technology Newsletter communicates developments in ceramic technology of advanced heat engines to over 1200 interested persons in the United States and abroad. The newsletter received the First Place Society for Technical Communication (STC) Award in February 1990. Another international newsletter, Radon Research Notes, which supports the DOE Office of Health and Environmental Research's Radon Research Program, was initiated and has evolved very satisfactorily. It describes radon research conducted by DOE, other federal agencies, and the Commission of European Communities, and is distributed to over 2200 interested persons.

An internal newsletter, HASRD safety notebook, is produced to assist in communicating safety information to the Health and Safety Research Division (HASRD) staff. This newsletter received a Third Place STC award. 


\title{
5. RISK ANALYSIS SECTION
}

\author{
C. C. Travis, Head
}

Staff

Research:
A. Q. Armstrong
D. B. Miller
V. J. Brumback
P. D. Miller
D. M. Douthat
J. L. Skiles
H. A. Hattemer-Frey
J. K. Thomas
M. L. Land
R. K. White
C. W. McGinn

Administrative Support:
A. G. Evers
S. R. Reynolds
V. L. Gamble
R. G. Selt
D. G. Henderson
L. E. Thurston

B. L. Ramsey

Subcontractors:
R. L. Adams
P. Atkins
M. E. Babb
J. C. Ball
H. Belefant
P. D. Birkner
B. P. Blaylock
R. R. Bonczek
L. R. Bond
J. Bowers
S. M. Boyens
R. A. Brothers
V. Chidambariah
A. G. Crotwell
K. R. Czor
R. K. Dabbs
H. C. Dees
C. B. Doty
L. A. Ferren
J. S. Foster
M. T. Fox
V. L. Gamble
M. S. Hanson

H. A. Hattemer-Frey
L. T. Helms
P. Henson
D. L. Johnson
A. D. King
R. C. Kramel
M. A. Kus
M. D. Land
M. L. Land
R. F. Lemak
S. Liu
C. W. McGinn
J. M. Morris
B. L. Neely
T. H. Newport
N. A. Nyberg
L. G. Osborne
K. J. Purcell
A. Redfearn
J. L. Skiles
M. E. Stack
B. L. Taylor
S. Tickle-Hester


J. K. Thomas

D. J. Upchurch

M. J. Waehner
K. A. Walter

L. A. Wang

D. A. White

\section{Postdoctoral Fellow:}

B. F. Lyon

Guest:

S. M. Book

Loanees from other divisions:

D. N. Clark ${ }^{1}$

C. Currie ${ }^{2}$

D. M. Hetrick'
K. L. Michel ${ }^{1}$

B. L. Neely ${ }^{2}$

M. W. Yambert ${ }^{1}$

${ }^{1}$ Computing and Telecommunications Division. ${ }^{2}$ Publications Division.

The mission of the Risk Analysis Section (RAS) is to develop and apply methodologies for assessing the human health impact of environmental pollutants, to implement effective waste management practices, and to provide programs in education and communication of risk. Research conducted in this section focuses on five major areas: hazardous waste; remediation of hazardous waste sites; computer-aided risk evaluation; molecular risk analysis; and education, training, and communication.

Cleanup of hazardous waste sites will continue to be a national priority for the next 10-15 years. The RAS staff is addressing the ongoing demand for research and development to provide cost-effective remediation of hazardous waste sites. Members of the staff serve as leaders and members of multifacility teams assigned by the Department of Energy (DOE) to demonstrate innovative remedial technology at various DOE sites. The staff members are also providing analytical evaluations of the effectiveness of remedial alternatives. Staff members recently completed a DOE pilot study to assess remedial action alternatives based on cost and health risk. The study was conducted in response to a request from the Office of Management and Budget (OMB). Although strong foundations in hazardous waste research and evaluation of remediation 
technologies are being developed by the RAS staff, more resources will be devoted to the critical areas of hazardous waste management and risk communication in upcoming months.

The section is also involved in improving computer-enhanced analyses of environmental data to support risk decisionmaking. The use of geographic information systems (GIS) as an analysis and risk management tool is being promoted at local and national levels. RAS staff, in conjunction with the Geographic Data Systems (GDS) section staff in the Computing and Telecommunications Division, are developing a prototype GIS for the Agency for Toxic Substances and Disease Registry (ATSDR) to support health assessments and other health studies at hazardous waste sites. RAS and GDS staff organized a GIS Information Exchange Meeting for GIS practitioners in environmental restoration programs at DOE facilities from across the nation held later in November 1991; this meeting was sponsored by the Center for Risk Management. RAS staff are also team leaders for the Oak Ridge Environmental Information System currently being developed to consolidate environmental data used for environmental restoration on the Oak Ridge Reservation.

The molecular risk analysis laboratory staff are using molecular biology as a tool to perform research to reduce uncertainties in the risk analysis process. They are currently developing molecular biology-based, short-term screening assays to evaluate chemicals for carcinogenicity, to assess media contaminants, and to assess contaminant concentrations.

All staff members are involved in promoting awareness and increasing understanding of human health and environmental risks to various audiences, including school-aged children, the general public, and risk professionals. The section served as mentor to a guest middle school science teacher in the summer of 1991 and is in the process of adopting local schools to assist them in science and risk education. Some of the staff members provide technical training workshops to human health and environmental risk professionals involved in health assessments and environmental remediation of hazardous waste sites.

Risk Analysis became a section in the Health and Safety Research Division in March 1991, after serving since 1984 as the Office of Risk Analysis. The section has experienced considerable growth and some reorganization has occurred during the last few months. A Hazardous Waste sroup was officially formed, and a summary of its activities follows. The formation of other groups is anticipated in the following months. 


\section{HAZARDOUS WASTE}

The Hazardous Waste group is involved in numerous activities related to the assessment and management of risks from hazardous materials, wastes, or sites. Much of the group's activities have been focused on the management of the DOE-OR Environmental Restoration (ER) Risk Assessment Program. The group (1) coordinates all risk assessment activities for the ER programs at five facilities: ORNL, Y-12, K-25, Paducah, and Portsmouth; (2) provides risk assessment policy and guidance; (3) performs assessments of the sites, and (4) oversees activities of numerous Energy Systems subcontractors and other DOE prime contractors in implementing risk assessment and risk management strategies in the cleanup of ER sites. In addition to managing the day-to-day implementation of the risk assessment program at the facilities, the group leads the Central Risk Assessment Council, a committee that develops guidance and resolves technical issues in order to improve the risk assessment methodology used to evaluate the impacts posed by the ER sites. Similar leadership in the use of risk assessment techniques and strategies for site cleanup is also provided to DOE facilities at Savannah River and the Idaho National Engineering Laboratory.

The Group is also very active in health risk-related training of other professionals. It provides all health assessment training for employees of ATSDR and for the employees of 25 state public health agencies involved in performing health assessments for the Superfund's National Priorities List sites. Through cooperative arrangements with ATSDR, the group is currently providing health assessment training to the bioenvironmental engineers, medical officers, and public health officers of the U.S. Air Force, with additional courses scheduled for similar personnel of the U.S. Army and the U.S. Navy. 


\title{
6. CENTER FOR RISK MANAGEMENT
}

\author{
C. C. Travis, Director
}

The Center for Risk Management, established as a center of excellence in June 1991, is housed in the Health and Safety Research Division and was established with the support of the Environmental Restoration Program. A major mission of the center is to focus the Laboratory's resources more strongly on evaluating risks to human health and on prioritizing and solving environmental problems related to energy production and consumption.

The Center for Risk Management will (1) improve communication between scientists working in different divisions and programs, (2) ensure that risk assessments and analysis performed for all sponsors meet the highest possible standards of technical excellence, (3) provide a common focus for marketing a laboratory-level initiative in risk assessment, analysis, and management, (4) assure the prior application of technical, social, and political input into our assessments, (5) promote training and educational initiatives aimed at professionals in the field and the public, and (6) establish Energy Systems as a national leader in the risk assessment area.

Examples of activities to be actively pursued by the center include environmental fate/transport modeling, human and environmental toxicology, epidemiology, applied ecology, environmental monitoring, data base development, and risk/benefit and policy analyses. The center will also provide technical assistance to sponsors responsible for performing or interpreting risk assessments and for managing societal risks. The center

sponsored a national Geographic Information Systems (GIS) information exchange meeting for GIS practitioners in environmental restoration programs at Department of Energy facilities to be held in November 1991.

As an interdisciplinary organization, the center will draw on the expertise of basic researchers within the divisions at Oak Ridge National Laboraatory (ORNL) that are active in risk-related research and application. The center reports to the ORNL Associate Director for Environmental, Life, and Social Sciences. 


\title{
7. CONTRIBUTIONS TO NATIONAL AND LEAD LABORATORY PROGRAMS AND ASSIGNMENTS
}

\author{
ENVIRONMENTAL RESTORATION \\ P. Y, Lu, C. C. Travis, and P. S. Rohwer
}

The Health and Safety Research Division (HASRD) has numerous and diverse initiatives with the Department of Energy (DOE) Environmental Restoration and Waste Management Program. These initiatives are at the local, national, and international level, and collectively represent the fastest growing area of research in HASRD.

The Risk Analysis Section (RAS) contributes to both local and national environmental restoration research and development (R\&D) efforts. At the local level, the extent and choice of environmental restoration strategy depends, in part, on estimates of human health and environmental risks. This Section provides risk assessment oversight of DOE-OR facilities to ensure consistent and reliable estimates of human health and environmental risks. The leader of the Hazardous Waste Group in the Section serves as the coordinator of the Central Risk Assessment Council (CRAC), and the Environmental Restoration Program; other staff serve as CRAC members. At the national level, a DOE environmental restoration priority is the development of technically feasible and cost-effective remedial alternatives for cleanup activities. DOE is currently conducting technical demonstrations of innovative remedial alternatives at various DOE facilities. RAS staff serve as leaders and members on these multifacility teams.

Effectiveness of current remedial action alternatives is another national DOE concern. DOE recently conducted a pilot project of remedial action alternatives based on cost and health risk. The study, conducted in response to a request from the Office of Management and Budget (OMB), involved estirnating the costs of remedial actions and estimating health risk reduction of remedial actions at 24 inactive contaminated sites located at DOE facilities. RAS staff conducted the health risk reduction reports for all of these sites.

The Biomedical and Environmental Information Analysis (BEIA) Section performs a number of developmental tasks for the local Environmental Restoration Program. For the contaminants of concern, toxicity profiles are written that identify the key information 
required for health risk assessment. In addition, the profiles identify existing toxicity values (i.e., Reference Doses, Reference Concentrations and slope factors) and, when one of the toxicity values has not been calculated, it presents the data that will serve as the basis of the calculation. BEIA staff then derive the missing toxicity value(s) for use in health risk assessment. PC-based expert systems were also developed for environmental safety and health applications: (1) National Environmental Policy Act (NEPA) Environmental Review and Compliance; and (2) internal assessment for compliance on eleven categories of environmental laws, including the Clean Air Act, Clean Water Act, Resources Conservation and Recovery Act (RCRA), Superfund Amendment Realuthorization Act (SARA), etc. BEIA staff members have collaborated with the project managers at ORNL, Y-12, K-25, and the Environmental Restoration Program of Energy Systems to compile monthly/quarterly environmental compliance reports. In addition to these activities, BEIA developed and maintained a number of data bases to track activities related to the Tiger Team audits and developed operational procedures and an audit checklist for ORNL, Y-12, and K-25 pertinent to Environment, Safety, and Health issues.

In addition to the large, applied programs in site characterization, the Assessment Technology (AT) Section is involved in environmental restoration R\&D activities on a national and international level. The staff members serve as consultants to the DOE Advisory Committee on Nuclear Facility Safety Subcommittee on cleanup. Providing expertise in hydrology and groundwater transport, the AT staff made significant contributions in a number of topical areas: (1) operation of the proposed DOE Environmental Restoration site prioritization system; (2) summarization of technical basis for decisionmaking for operable units at DOE-ER sites; (3) information transfer within the DOE-ER complex and between DOE-ER sites; and (4) subsurface cleanup technologies. The staff also served as the principal author of the subcommittee's final report to the Secretary of Energy. At the invitation of DOE, they also participated as U.S. representatives in an International Atomic Energy Agency (IAEA) model intercomparison study (the IAEA Coordinated Research Program [CRP] on the Safety Assessment of Near-Surface Radioactive Waste Disposal Facilities). The CRP was designed to compare results of various environmental transport models when predicting releases and potential impacts from selected test cases. The following tasks were completed: (1) developed a near-field model to determine the release of radionuclides to the geosphere using the TIME-ZERO computer code; (2) developed an intruder dose assessment code (INTRUD) that implemented construction and agriculture scenarios for a time-dependent 
source term; (3) modified the NRC GRND computer code to use as a groundwater transport model; (4) modeled groundwater transport of radionuclides released from two disposal test cases; (5) determined the resultant doses to a recipient drinking contaminated groundwater; and (6) prepared a draft report documenting results of the CRP test case runs. Results of the test cases were presented at the IAEA's First Coordinated Research Meeting in Vienna, Austria, July 1-5, 1991. The results were well received by other CRP participants and agreed quite well with results from the other 13 participating countries. 
APPENDIXES 


\section{APPENDIX A. SOURCES OF FUNDING}

\section{DEPAR'TMEN'T OF INERGY}

Biological and Envirommental Research

Remedial Actlon and Waste Technology

$\$ 6,207$

Environmental Research and Development

3,418

Electric Energy Systems

1,084

Defense Waste and Environmental Restoration

$4(08$

Energy Storige Systems

Multlprogram - Facllitles Support

Fossil Energy - Coal

Solar Energy

$2,7(0) 7$

Industrial Energy Conservation

Transportation

\section{DEPAR'TMENT OF DEFEMSE}

Air Force (including HAZWRAP)

Navy (including DSRD)

Army

Defense Nuclear Agency

\section{O'THER FEDERAL AGENCIES}

Environmental Protection Agency

Department of Health and Human Services

National Library of Medicine

Agency for Toxic Substances and Disease Registry

National Institute of General Medical Sclences

Health and Human Services

Nuclear Regulatory Commission

Bureau of Land Management.

Office of the Inspector General

\section{O'THER DOE}

Battelle Pacific Northwest Laboratory

Bendix

Sandia National Laboratories

Savannah River National Laboratory

Chem-Nuclear Electrical

EG\&G Reynolds Electrical 
$\mathrm{K}-25$

2,419

ORO/ORAU

3)

EG\&G Iduho

16

Multiplant

38()

ORO/Energy Systems

213

Portsmouth

10()

PGDP

195

\section{PRIVATE, S'TATE AND LOCAL GOVERNMENT}

New York University

Federal Republic of Germany

American Petroleum Institute

Radiation Effects Research Foundation

99

Soap and Detergent Association

9

Environmental Systems Corporation

28

Colorado State University

\section{INTERNAL ORNL}

Seed Money and Discretionary Funds

Laboratory Overhead Accounts

119

TOTAL Division

$\$ 32,310$ 


\section{APPENDIX B. PERSONNEL SUMMARY}

\begin{tabular}{lcccr}
\hline & Professional & $\begin{array}{c}\text { Technical } \\
\text { Support }\end{array}$ & $\begin{array}{c}\text { Administrative } \\
\text { Support }\end{array}$ & T'otal \\
\hline Permanent & 11 & 26 & 29 & 166 \\
Temporary & 13 & 7 & 2 & 22 \\
Purt-time & 14 & 1 & 3 & 18 \\
Leave of absence & 1 & 0 & 0 & 1 \\
Oft-site assignment & 3 & 0 & 0 & 3 \\
Division-supported loanees & 18 & 3 & 0 & 21 \\
\hline
\end{tabular}

Many types of employees are required to run the division effectively and efficiently. Several sources are used to staff the division to maintain the high standards. During this reporting period, we have had a total of 302 assignments to the division in the following categorles: consultants, subcontractors, guests from universities, visiting scientists from other laboratorles as well as private companies, postdoctoral fellows, and students who come to us under several different programs. Assignment terms vary in duration from a few months to a year or more. We view this as a very economical way to bring different and diversified talents to the division. 

6.3 i
APPENIII C. ORGANIZATION
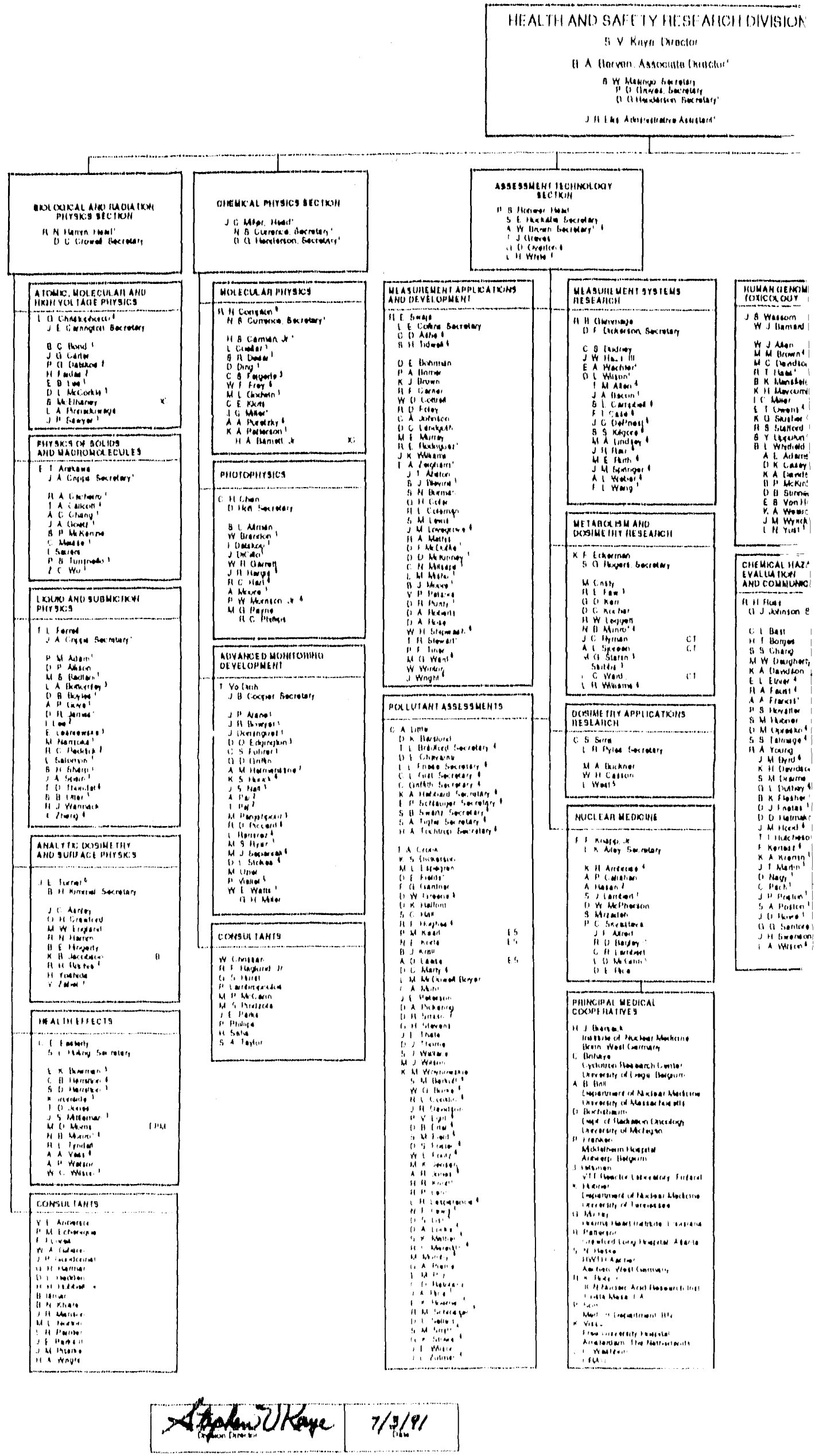


\section{('HAR'T}
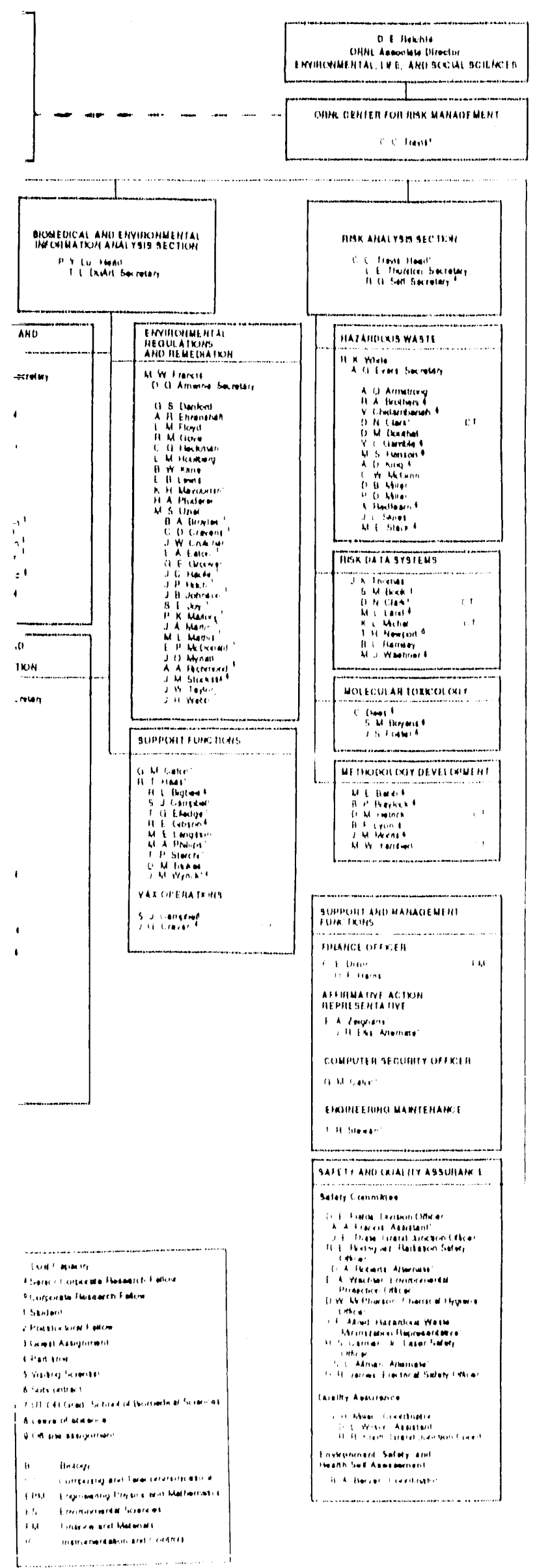


\title{
APPENDIX D. SEMINAR PROGRAM
}

\author{
P. C. Srivastava
}

The coordirator of the Health and Safety Research Division's seminar program works with staff members to identify distinguished seminar speakers from various disciplines of research interest to the Division.

During the period April 2, 1990, through July 31, 1991, the Division hosted 17 seminar speakers representing industry, research institutions, and universities. Many of these appeared under the auspices of the Chemical Physics Seminar series (J. C. Miller, Coordinator).

\section{Guillanme Petite}

Centre d'Etudes Nucleaires de Saclay, France, "Electron Energy Spectra in Multiphoton Photoemission," June 8, 1990.

\section{Takashi Akahane}

National Institute for Research in Inorganic Materials, Ibaraki, Japan, "Stretching of Slow Positron Pulses Generated With an Electron LINAC," June 27, 1990.

Syctney Leach

Observatoire de Paris-Meudon, Paris, France, "The Photofragmentation of Some Molecular Cations of Astrophysical Interest," September 5, 1990.

\section{J. M. Wetser}

Technische Universiteit Eindhoven, The Netherlands, "Avalanches in Electronegative Gases," September 21, 1990.

\section{Thomas G. Thundat}

Arizona State University, Tempe, Arizona, "Electrodeposition of DNA Molecules for Structural Investigation by STM," October 3, 1990.

\section{Eugen Illenberger}

Freie Universitat Berlin, Germany, "Electron Capture and Relaxation Processes in Molecular Aggregates," October 5, 1990.

Lloyd M. Davis

The University of Tennessee Space Institute, Tullahoma, Tennessee "Studies of Picosecond Breakdown Phenomena," October 12, 1990. 
R. N. Zare

Department of Chemistry, Stanford University, Stanford, California, "State-Selected and State-Detected Ion-Molecule Reactions," October 26, 1990.

$J u n X u$

Department of Physics, Vanderbilt University, Nashville, Tennessee "Electron and Photon Stimulated Desorption of Excited $\mathrm{CN}$ from Alkali Metal and Alkali Halide Surfaces," February 20, 1991.

Francois Wuilleumier

Universite de Paris-Sud, France, "Photoionization of Ions," March 11, 1991.

\section{Richard V. Graham}

The University of Tennessee, Knoxville, Tennessee, "Comparison of Selenomethionine and Selenite Cycling in Freshwater," April 18, 1990.

\section{A. P. Hickman}

SRI International, Menlo Park, California, "Theory of Fine-Structure Changing Collisions of Excited Xenon," April 19, 1991.

\section{A. A. Puretzky}

Institute of Spectroscopy, USSR Academy of Sciences, Troitsk, Moscow Region, USSR, "Gas-Phase Formation of Rydberg Atoms, Clusters, and Ultra-Fine Particles in UV Multiphoton Excitation of Metal Carbonyls," May 6, 1991.

\section{J. C. Davis}

Center for Accelerator Mass Spectrometry, Lawrence Livermore National Laboratory, Berkeley, California, "Accelerator Microanalytical Techniques at LLNL," May 14, 1991.

\section{Klans Wendt}

Institute fur Physik, Johannes Guttenberg-Universitat Mainz, Mainz, Germany, "Resonance Ionization Spectroscopy for the Quantitative Detection of Strontium-9() and Strontium-89 in Environmental Samples," May 3, 1991.

Roger C. Hart

The University of Tennessee Department of Physics and Health and Safety Research Division, ORNL, "Interference Effects Due to Four-Wave Mixing in Multiphoton Ionization," Maly 23, 1991. 


\section{John Bertram}

Cancer Research Center of Hawaii, University of Hawaii, "Mechanistic Studies of Cancer Preventive Agents Using In Vitro Systems: Proposed Role of Junctional Communication,"

July $31,1991$. 


\section{APPENDIX E. LIST OF HONORS AND AWARDS FOR STAFF MEMBERS}

\section{SPECIAL HONORS}

L. G. Christophorou

Recipient of the Senior U.S. Scientist Award from the Alexander von Humboldt Foundation of Berlin, Germany, in recognition of his past accomplishments in research and teaching

P. C. Srivastava

Recipient of the United Nations World Development Program Award for Distinguished Scientists for the development of collaborative programs in the area of radiopharmaceutical and chemotherapeutic agents in association with Council of Scientific and Industrial Research Scientists in India (1990-1991)

T. Vo-Dinh

Appointed Senior Research Associate Board Member, Environmental Research Center, University of Nevada, Las Vegas, Nevada

A. P. Watson

Recipient of the Outstanding Leader and Advocate Award of the East Tennessee Chapter of the Association for Women in Science, 1991

Finalist for the Science and Technology Award, Knoxville YWCA Tribute to Women, 1991

\section{R\&D-100 AWARD}

A. B. Ahmed, R. S. Bogard, and M. A. Buckner "Harshaw 8800 'TLD System"

P. C. Srivastava and J. F. Allred

"Iodophenylmalemide Radioimmunoconjugator"

\section{SPECIAL AWARDS}

S. L. Allman and R. C. Phillips

Martin Marietta Energy Systems, Inc. 1991 Technical Achievement Award

D. K. Barslund

Health and Safety Research Division Distinguished Achievement Award for Administrative Support for 1990

C. H. Chen

Health and Safety Research Division Excellence in Research Award for 1990) 
L. G. Christophorou

Senior Corporate Fellow, 1991

K. A. Davidson

Diplomate, American Board of Toxicology, 1990)

National Toxicology Program, Board of Scientific Counselors, Technical Review Subcommittee, 1991

M. E. Langston

Health and Safety Research Division Distinguished Achievement Award for Technical Support for 1991

B. L. Ramsey

Health and Safety Research Division Distinguished Achievement Award for Administrative Support for 1991

P. S. Rohwer

Martin Marietta Energy Systems, Inc. 1991 Operations and Support Award

J. E. Thate

Health and Safety Research Division Distinguished Achievement Award for Technical Support for 1990

R. A. Young

Diplomate, American Board of Toxicology, 1990

\section{PUBLICATION AWARDS}

K. R. Ambrose

1991 Publications and Art Competition Winners for "Integrated Environmental Assessment for a Major Project" (co-author), East Tennessee Chapter of the Society for Technical Communication, February 1991

David E. Fields, Marilyn Langston, and Information Management Technology Group Society for Technical Communication 1991 Achievement Award for HASRD safety notebook

B. E. Hingerty

Technical Communication Award (Merit in Trade/News Articles - article appeared in the Human Genome Project in the ORNL Review, 1990)

Betty K. Mansfield, W. Edward Barker, and Judy M. Wyrick Society for Technical Communication 1991 Distinction Award for DOE Human Genome Management Information System

Betty K. Mansfield, Judy M. Wyrick, and Anne E. Adamson Society for Technical Communication 1991 Distinguished Award for Human Genome News 
P. C. Srivastava

Martin Marietta Energy Systems, Inc. 1991 Publication Award

A. P. Watson, K. R. Ambrose, G. D. Griffin, N. B. Munro, L. C. Waters, and S. Carnes

Distinguished Technical Reports Award for special issue of The Environmental Professional, 1991, East Tennessee Chapter of the Society for Technical Communication

Judy M. Wyrick, Betty K. Mansfield, and Vicki L. Conner

Society for Technical Communication 1991 Merit Award for Human Genome 1989-1990 Program Report

Judy M. Wyrick, Gloria M. Caton, and the Ceramic Technology Staff

Society for Technical Communication Achievement Award for Ceramic Technology Newsletter

\section{COMMITTEE APPOINTMENTS}

E. T. Arakawa

Member, International Advisory Board, Vacuum Ultraviolet Radiation Physics Group, 1989 - 1992

A. Q. Armstrong

Member, DOE Integrated Technology Demonstration Committee for Cleanup of Uranium Contaminated Soils, 1990 - present

B. A. Berven

Chairman, Environmental Section of the Health Physics Society Standards Committee, 1985 - present

J. E. Carrington

Member, ORNL/Martin Marietta Energy Systems, Inc., Values Committee, 1988 1990

G. M. Caton

Chair, American Society for Information Science for WATTec 1991 "Science in Action" Education Program

Member, Professionalism Committee of American Soxiety for Information Science, 1991

L. G, Christophorou

Member, ORNL/Publications Selection Committee, 1990 - present

Chairman, ORNL Corporate Fellow's Council, 1990 - present 
R. N. Compton

Member, Panel of Public Affairs (POPA), American Physical Sociely, 1989present

Member, Publications Committee of the American Physical Society, 1991 - present

Chairman, Committee on Geosciences, Corporate Fellows' Council at ORNL, 1990

M. Cristy

Member, Task Group on Dose Calculations, Committee 2 on Secondary Limits, International Commission on Radiological Protection, 1985 - present

Vice-Chairman, Task Group on Revision of Reference Man, Committee 2 on Secondary Limits, International Commission on Radiological Protection, 1985 . present

Corresponding member, Task Group on Age-Dependent Dosimetry, Committee 2 on Secondary Limits, International Commission on Radiological Protection, 1988 present

D. F. Dickerson

Member, ORNL/Martin Marietta Energy Systems, Inc., Values Committee, 1991 present

C. E. Easterly

Member, Electromagnetics Subpanel of the Free-Electron Hazards Advisory Panel, U.S. Army Environmental Hygiene Agency, 1988 - present

Member, Subcommittee on Dose Assessment, DOE Emergency Management Coordinating Committee, 1989 - present

Member, ASTM Subcommittee E34.70, Single Crystal Whiskers, Committee E-34 on Occupational Health and Safety, 1988 - present

Member, Monitoring and Modeling Subcommittee of the Oak Ridge Full-Scale Exercise Advisory Committee, 1988 - present

K. F. Eckerman

Member, Task Group on Modeling and Scaling to Humans, DOE, 1985 - present

Member, National Council on Radiation Protection and Measurements, 1990)

Member, Committee 2 on Secondary Limits, International Commission on Radiological Protection, 1982 - present

Chairman, Task Group on Dose Calculations, Committee 2 on Seconcliry limits, International Commission on Radiological Protection, 1982 - present 
Member, Trisk Group on Age-Dependent Dosimetry, Committee 2 on Secondary Limits, International Commission on Radiological Protection, 1988 - present

Member, Scientific Committee 57, Internal Emitter Standards, National Council on Radiation Protection and Measurements, 1979 - present

Member, Scientific Committee 64, Task Group 5, Public Exposure from Nuclear Power, National Council on Radiation Protection and Measurements, 1979 present

Member, Scientific Committee 64, Task Group 6, Screening Models, National Council on Radiation Protection and Measurements, 1979 - present

Member, Advisory Group, Health Effects Model Revision, Nuclear Regulatory Commission, 1980 - present

Member, Scientific Committee '84, Radicnuclide Contamination, National Council on Radiation Protection and Measurements, 1991 - present

R. D. Foley

Member, ORNL Radioactive Operations Committee, 1990 - present

R. B. Gammage

Member, Indoor Air Quality Committee, American Industrial Hygiene Association, 1985 - present

Member, DOE Research Development Demonstration Testing and Evaluation Working Group for Instrumentation, 1989 - present

J. W, Haas, III

Vice-Chairman, ASTM E13.08 Committee on Raman Spectroscopy, 1990 - present

T. D. Jones

Member, DOE Environmental Standards Steering Committee, 199() - present

S. V. Kaye

Member, Advisory Committee, ORAU/DOE Health Physics Faculty Research Award Program, 1991 - present

D. C. Kocher

Member, Standards Committee, Health Physics Society, 1987 - present

Member, DOE's Performance Assessment Task Team for Low-level Radioactive Waste Disposal, 1991 - present

R. W. Leggett

Member, Task Group on Dose Calculations, Committee 2 on Secondary Limits, International Commission on Radiological Protection, 1985 - present 
Corresponding Member, Task Group on Reference Man, Committee 2 on Secondary Limits, International Commission on Radiologic Protection, 1990 present

Member, Task Group on Age-Dependent Dosimetry, Committee 2 on Secondary Limits, International Commission on Radiological Protection, 1990 - present

C. A. Little

Member, Nominating Committee, Health Physics Society, 1990

P. Y. Lu

Member, National Safety Council, Executive Committee Chemical Section, 1985 present

Program Chairman, Chemical Health and Safety Division, American Chemical Scoiety, 1990 - present

Member, DOE/OR Environmental Restoration Council, 1990 - 1991

L. M. McDowell-Boyer

Member, Cleanup Subcommittee of the DOE Advisory Committee on Nuclear Facility Safety, 1991 - present

P. D. Miller

Member, DOE/OR Technical Oversight Review Committee for Environmental Restoration, 1990 - present

M. E. Murray

Member, ORNL Radioactive Operations Comnittee, 1990 - present

R. H. Ritchie

Member, Executive Council, Southeastern Section, American Physical Society, 1986 - present

P. S. Rohwer

Member, ORAU/DOE Health Physics Fellowship Selection Committee, 1990 present

R. H. Ross

Member, DOE/OR Environmental Restoration Council, 1990 - 1991

I. Sauers

Subcommittee Chairman, IEEE Gaseous Dielectrics Committee S-32-11, 1986 . present

C. S. Sims

Chairman, Technical Committee on Procedures and Data for the Intercomparison of Personnel Dosimeters, International Atomic Energy Agency, 1984 - present

Chairman, Technical Committee on Assessment of Occupational Exposure to External Radiation for Monitoring Purposes, International Atomic Energy Agency, 1985 - present 
Chairman, ANS1 N13.11 Review Working Group, Henlth Physics Soclety, 1987 . present

P. C. Srivastava

Member, National Institutes of Health Advisory Committee, Development Therapeutics Contracts Program, 1987 - present

R. E. Swaja

Member, ANSI N319 Committee on Personnel Neutron Dosimetry, Health Physics Society, 1986 - present

Chairman, ASTM E10.04 Committee on Criticality Accident Dosimetry, 1986 present

D. J. Thorne

Participant, IAEA Coordinate Research Program Safety Assessment of NearSurface Radioactive Waste Disposal Facility, 1991 - present

C. C. Travis

Chairman, Scientific Bases for Risk Assessment Assumptions, Office of Science and Technology Policy, 1986 - present

Member, Science Advisory Board, Food and Drug Administration, 1987 - present

Member, Delivered Dose Work Group, American Industrial Health Council, 1987 present

Member, State of New Jersey Governor's Science Advisory Board on Health and Environmental Issues, 1988 - present

Member, New Jersey State Department of Health Advisory Panel on Superfund Sites, 1988 - present

Member, State of Maryland Advisory Panel on the Maryland Power Plant Research Program, 1988 - present

Member, Technical Advisory Committee (TAC) to the New York City Sludge Management Plan, $1989-1992$

Member, National Academy of Sciences Board on Radioactive Waste Management to Review the Idaho National Engineering Laboratory activities, 1989 - present

Member, National Academy of Sciences Board on Radioactive Waste Management Committee to Review Hanford Single Shell Tanks, 1989 - present

Member, Advisory Panel, National Environmental Restoration Prioritization Program, 1989 - present

Member, National Academy of Sciences Committee on Biomarkers for Immunotoxicology, 1989 - present 
Member, The Federal Insecticide, Fungicide, and Rodenticide Act (TIFRA) Scientific Advisory Panel, Environmental Protection Agency, 199() - 1994

President, International Soclety for Risk Analysis, 1990 - 1991

Member, Environmental Protection Agency Revlew Panel for Dermul Exposure Assessment, 1991

Member, Science Advisory Paneh, Chemical Industry Institute of Toxicology, 1991

Member, National Academy of Sciences Committee on Remedial Action Prioritles for Hazardous Waste Sltes, 1991 - present

J. E. Turner

Member, Comprehensive Certification Panel of Examiners, American Board of Health Physics, 1987 - present

Member, RERF Advisory Dosimetry Subcommittee, National Research Council, 1988 - present

Consociate Member, National Council on Radiation Protection and Measurements, 1983 - present

T. Vo-Dinh

Co-chairman, International Committee on Polycyclic Aromatic Compounds, 1985 present

Chairman, Commission V.4 on Spectrochemical Methods, International Union of Pure and Applied Chemistry (IUPAC), 1991 - present

Chairman, Subcommittee on Fiberoptics, ASTM Committee E.13, 1989 - present

J. S. Wassom

Chairman, Communication and Archives Committee, Environmental Mutagen Society, 1982 - present

Councilor, Environmental Mutagen Society, 1987 - present

Member, Environmental Mutagen Society, Organization and Structure Committee, $1990-1991$

A. P. Watson

Member, Reentry/Restoration Subcommittee of the Chemical Stockpile Disposal Program Steering Committee, Department of the Army and the Federal Emergency Management Agency (FEMA), 1989 - present

Member, ORNL Publications Award Selection Cornmittee, 1990) - present

R, K. White

Member, American Society for Testing and Materials (ASI'M) Committee on Risk Assessment, 1991 - present 
Chatrman, DOE/OR Endronmental Restoration Rlsk Assessment Councll, 199(). 1991

Member, DOE Envirommental Ocoupational and Public Health Standards Committee, 1991 - present

\section{JOURNAL ACKNOWLEDGMENTS}

F. F. Knapp, Jr,

Member, Editoriul Board, NucCompact-European/American Communications in Nuclear Medicine, 1989 - present

K. H. Mavournin Member, Editorial Board, Environmental and Molecular Mutagenesis, 1985. present

C. S. Sims

Associate Editor, Health Physics, 1990 - present

C. C. Travis

Editor-in-Chief, Risk Analysis: An International Journal, 1983 - present

Member, Editorial Advisory Board, Toxicological and Environmental Chemistry, 1989 - present

Member, Editorial Board, Health and Environmental Toxicology, 1989 - present

Member, Editorial Board, Toxicology and Industrial Health, 1990) - present

Member, Editorial Board, Journal of Hazardous Materials, 1990-1993

Member, Advisory Board, Critical Reviews in Environmental Control, 1991

J. E. Turner

Associate Editor, Radiation Research, 1991 - present

T. Vo-Dinh

Member, Editorial Board, Applied Spectroscopy, 1988 - present

'Topical Editor, Polycyclic Aromatic Compounds, 1989 - present

Member, Advisory Board, Spectrochimica Acta Reviews, 1990 - present

Member, Advisory Board, Talanta, 1990 - present

Associate Editor, ANALUSIS, 1991 - present

E. A. Wachter

Member, Interagency Steering Committee on Standoff Deflction, 1990-present 
J. S. Wussom

Member, Bourd of Managing Editors, Mutation Research, 1975 - present

R, K. White

Member, Editorlal Board, Risk Analysis: An International Journal, 1989- 1991

Book Review Editor, Risk Analysis: An International Journal, 1987 - present

\section{UNIVERSITY APPOINTMENTS}

E. T. Arakawa

Adjunct Professor of Physics, University of Tennessee, 1982 - present

C. H. Chen

Adjunct Professor of Physics, University of Tennessee, 1990-present

Adjunct Professor of Physics, Vanderbilt University, 1990 - present

L. G. Christophorou

Professor of Physics, University of Tennessee, 1969 - present

R. N. Compton

Adjunct Professor of Physics, Vanderbilt University, 1983 - present

Professor of Chemistry, University of Tennessee, 1985 - present

T. L. Ferrell

Professor of Physics, University of Tennessee, 1979 - present

W. R. Garrett

Adjunct Professor of Physics, University of Tennessee, 1990)

D. C. Kocher

Faculty Affiliate, Department of Radiological Health Sciences, Colorado State University, 1990-present

C. A. Little

Adjunct Professor of Radiology and Radiation Biology, Colorado State University, 1987 - present

L. A. Pinnaduwage

Adjunct Assistant Professor of Physics, University of Tennessee, 1991 - present

R. H. Ritchie

Professor of Physics, University of Tennessee, 1965 - present

C. S. Sims

Adjunct Assistant Professor, Texas A\&M University, 1990 
P. C. Srivastava

Adjunct Professor, Blomedical Sciences, University of Tennessee, 1991 - present

C. C. Travis

Senlor Research Fellow with the Energy, Environment, and Resources Center, University of T"ennessee, 1990 - present

J. E. Turner

Professor of Physics (part-time), University of Tennessee, 1981 - present

Adjunct Professor of Nuclear Engineering, University of Tennessee, 1990 present

R, L. Tyndall

Associate Professor of Research, Zoology Department, University of Tennessee, 1978 - present

M. Uziel

Professor of Biomedical Sciences (part-time), University of Tennessee, 1968 present

T. Vo-Dinh

Professor of Biomedical Sciences (part-time), University of Tennessee, 1987 . present

R. J. Warmack

Professor of Phystcs, University of Tennessee, 1983 - present

\section{OTHER}

G. M. Caton

Treasurer, Oak Ridge Chapter of Sigma Xi, 1983-1987

Chair, East Tennessee Chapter, American Society for Information Science, 1991

R. N. Compton and J.A.D. Stockdale

Recipients, NATO International Collaboration Grant, 1988 - 1990

K. F. Eckerman

Consultant, Sloan-Kettering Memorial Medical Center, 1981 - present

B. E. Hingerty

Consultant, New York University, 1978 - present

S. V. Kaye

Consultant, U.S. Department of Veteran Affairs, 1989 - present

G. D, Kerr

Consultant, Radiation Effects Research Foundation, Japan, 1975 - present 
C. E. Klots

Recipient, NATO International Collaboration Grant, 1990 - present

D. C. Kocher

Visiting Professor, Department of Radiology and Radiation Biology, Colorado

State University, 1989 - 1990

J. C. Miller

Elected Fellow, American Optical Society, 1991

Recipient, NATO International Collaboration Grant, 1987 - present

R. H. Ritchie

Recipient, Grant from National Science Foundation for U.S.-Japan Collaborative Research, $1988-1990$

Member, Board of Directors, Pellissippi International, Inc., 1987 - present

Member, Advisory Board, Atom Sciences, Inc. 1984 - present

P. S. Rohwer

Treasurer, Health Physics Society, 1991 - 1993

Fresident-elect, American Academy of Health Physics, 1991 - 1992

C. S. Sims

U.S. Dosimetry Contact for the Joint Standing Committee for Civil Nuclear Cooperation with Taiwan, Republic of China, 1985 - present

C. C. Travis

Recipient, NATO Scientific Affairs Division Grant, 1991

J. E. Turner

President-elect, American Academy of Health Physics, 1992

R. L. Tyndall

Consultant, Northern States Power Company, 1980 - present

Consultant, Perkin-Elmer Cetus, 1991

Consultant, Anderson County School System, 1991

T. Vo-Dinh

Secretary, American Institute of Chemists (Tennessee Section), 1989 - present

A. P. Watson

Chair, Admissions Committee, Oak Ridge Chapter of Sigma Xi, 1989 - 1991 


\section{APPENDIX F. PATENTS GRANTED TO STAFF MEMBERS}

\section{PATENTS ISSUED}

Loucas G. Christophorou and Homer Faidas

"Dielectric Liquid Pulsed-Power Switch," U. S. Patent No. 4,970,434, November 13,1990

Loucas G. Christophorou

"Binary and Ternary Gas Mixtures with Temperatue Enhanced Diffuse Glow Discharge Characteristics for Use in Closing Switches," U. S. Patent No. $4,937,500$, June 26,1990

R. N. Compton

"High Brilliance Negative Ion and Neutral Beam Source," U. S. Patent No. $5,019,705$, May 28, 1991

Thomas L. Ferrell, Robert J. Warmack, and Robin C. Reddick "Photon Scanning Tunneling Microscopy," U.S. Patent No. 5,018,865, May 28, 1991

Mark M. Goodman and Furn F. Knapp, Jr.

"Aminopropyl Thiophene Compounds," U.S. Patent No. 4,914,215, April 3, 1990

Mark M. Goodman and Furn F. Knapp, Jr.

"Radioiodinated Branched Carbohydrates," U.S. Patent No. 1,826,966, May 2, 1990

Robert N. Hamm, Scott R. Hunter, George S. Hurst, James E. Turner, and Harvel A. Wright

"Ionizing Radiation Detector System," U. S. Patent No. 4,931,653, June 5, 1990

\section{INVENTION DISCLOSURES}

Steve L. Allman, Fang C. Chen, and Chung H. Chen

"Electron Attachment Freon Leak Detector," May 1990 (ESID 794-X, S-71,430)

(Assignment - August 1990)

Alvin P. Callahan and Dennis E. Rice

"Improved Tungsten-188/Rhenium-188 Generator System," July 19! () (ESID

831-X, S-71,464) (Assignment - August 1990)

C. H. Chen, W. R. Garrett, R. C. Phillips, and M. G. Payne

"Goggle to Protect Against Tunable Laser Weapons," April 1990 (ESID 783-X, S-72,419) 
Chung-Hsuan Chen

"Machinable Dissolved Metal Oxide Superconductors," June 1990)(ESID 806-X, S-71,443) (Assignment - July 1990)

Chung-Hsuan Chen and Michael P. McCann

"Improved Process for Preparing Bi-Sr-Ca-Cu-O Superconductors," July 1990

(ESID 805-X, S-71,442) (Assignment - 1990)

Chung-Hsuan Chen and Marvin G. Payne

"Vacuum Ultraviolet lonizer DNA Sequencer," November 1990 (ESID 906-X, S-72,448)

Fang C. Chen and Chung-Hsuan Chen

"Photoelectron Ion Mobility Freon Leak Detector," April 1990 (ESID 777-X,

S-71,415) (Assignment - August 1990)

F. C. Chen and C. H. Chen

"Fluorescence Detector for Non-Chlorine-Containing Freons," April 1990 (ESID

787-X,

S-71,423)

F. C. Chen, S. L. Allman, and C. H. Chen

"Optical Refrigerant Charge Inventory Monitor," January 1991 (ESID 920-X

S-72,460)

R. N. Compton and W. F. Frey

"Metal Vapor Heat Pipe Dosimeter," May 1991 (ESID 648-X)

R. N. Compton and W. F. Frey

"Method for Separating Fullerenes from Raw Soot," July 1991 (ESID 1012-X, S-73,564)

H. Craig Dees and Curtis C. Travis

"Cell Line and Bioassay for Lipidermal Growth Factor," November 1990 (ESID

905-X, S-72,446)

H. Craig Dees and Curtis C. Travis

"Chemical Carcinogenicity Assay Using Tumor Suppressor Gene Products," August 1991 (ESID 1028-X, S-73,581)

Clay E. Easterly

"Thermal Gun," June 1991 (ESID 995-X, S-73,547)

William R. Garrett and Marvin G. Payne

"Laser Isotope Separation Method," July 1990 (ESID 828-X, S-71,4t2)

(Assignment - August 1990)

William R. Garrett, James J. DiCillo, Chung-Hsuan Chen, and Marvin G. Payne

"Refractive Index Matching Eye Protector," June 1991 (ESID 997-C, S-7.3,.50) 
C. J. Janke, J. D. Muhs, L. G. Powell, E. A. Wachter, N. R. Smyrl and T. L. Hatmaker "Heat Damage Detection Techniques for Polymer Matrix Composites," October 1990 (ESID 885-K)

Peter M. Kearl and Thomas A. Cronk

"Optical Instrument for Measuring Particle Velocities in Groundwater," October 1990 (ESID 890-X, S-72, 428)

F. F. Knapp, Jr., A. P. Callahan, and S. Mirzadeh

"Osmium-194/Iridium-194 Radionuclide Generator System," July 1990 (ESID

$813-X, S-71,460)$

F. F. Knapp, Jr., E. C. Lisic, S. Mirzadeh, and A. P. Callahan

"Tungsten-188/Carrier Free Re-188 Perrhenic Acid Generator System," September 1990 (ESID 877-X, S-72,417)

Dan W. McPherson

"1-Azabicyclo[2.2.2]Oct-3-yl $\alpha$-Hydroxy- $\alpha$-phenyl- $\alpha$-(Radiolabeled alkenyl and

alkyl)- $\alpha$-phenylacetates (QNP)," August 1991 (ESID 1013-X, S-73,565)

Saed Mirzadeh

"Process for Preparing Copper-64 and Copper-67 Isotopes," August 24, 1990 (ESID $846-X, S-71,480)$

Saed Mirzadeh and Furn F. Knapp, Jr.

"Extraction-Based ${ }^{194}$ Os/ ${ }^{194}$ Ir Radionuclide Generator Systems," April 1991 (ESID 968-X, S-73,519)

H. A. Pfuderer, H. L. Fellers, Jr., J. W. Crutcher, and K. C. Miller

"Combination Smartforms Expert System, Database, and Automated Forms Software for Stack Release Air Permits," September 1990 (ESID 859-X, S-72,400)

Prem C. Srivastava and Ahmad Hasan

"Acyclonucleosides of 2-Nitroimidazole and Uses as Diagnostic and Therapeutic Agents," (ESID 738-X, S-70,482) (Assignment - June 1990)

Curtis C. Travis

"Novel Marked Liver Cell Line," May 1991 (ESID 980-X, S-73,351)

Curtis C. Travis and H. Craig Dees

"Method for Repairing Biochemical Deficiencies," August 1991 (ESID 1025-X, S-73,578)

R. L. Tyndall

"Amoeba/Bacteria Consortia and Related Process for Degrading TCE and Other

Wastes and Contaminants," April 1990 (ESID 702-X)

Richard L. Tyndall and Arpad A. Vass

"Rescue or Creation of Bacterial Populations by Passage through Protozoa,"

September 1991 (ESID 1034-X., S-73,588) 
Mayo Uziel and Kelly Houck

"FABA - A Fluorescent Reporter Group," August 1991 (ESID 1030-X, S-73,583)

Tuan Vo-Dinh

"Chemical Coating Based SERS Substrates," April 1990 (ESID 760-X, S-70,490)

Tuan Vo-Dinh

"Personal Dosimeter Using SERS," June 1990 (ESID 800-X)

T. Vo-Dinh

"Erasable Surface Enhanced Raman Scattering Optical Data Storage (SERODS)

System," August 1990 (ESID 849-X, S-71,483)

Tuan Vo-Dinh

"Enhanced Photo-Activated Luminescence for Screening Chlorinated Compounds," September 1991 (ESID 1035-X, S-73,589)

Eric A. Wachter and John W. Haas, III

"Improved Needle Substrates for SERS and ESERS Analysis," April 1990 (ESID

735-X, S-70,477) 


\section{APPENDIX G. MEETINGS AND CONFERENCES}

10th ORNL Life Sciences Symposium, Hazardous Waste Site Investigations: Toward Better Decisions, Gatliwbstrg, Tennessee, May 21-24, 1990. Chairpersons: R. B. Gammage and B. A. Beretret, Oak Ridge National Laboratory. Sponsor: EPA, DOE-OHER, and HAZWVRMP.

Access and Use of Information Resources in Assessing Health Risks from Chemical Exposure, Oak Ridge, Tennessee, June 27-29, 1990. Organizers: P. Y. Lu and J. S. Wassom, Oak Ridge National Laboratory; C. T. DeRosa and W. H. McFariand, Environmental Protection Agency. Sponsors: Health and Safety Research Division and the Office of Criteria Assessment, U.S. Environmental Protection Agency.

Sixth International Symposium on Gaseous Dielectrics, Knoxville, Tennessee, September 23-27, 1990. Chairpersons: L. G. Christophorou and I. Sauers, Oak I idge National Laboratory. Sponsors: Health and Safety Research Division, DOE/OHER, and University of Tennessee.

Workshop on Advanced Laser Technology for Chemical Measurements, Oak Ridge, Tennessee, November 12-14, 1990. Chairpersons: W. R. Garrett and J. C. Miller, Oak Ridge Natonal Laboratory. Sponsors: Health and Safety Research Division and DOE/OHER.

Workshop on Laser Ablation-Mechanisms and Applications, Oak Ridge, Tennessee, April 8-10, 1991. Chairperson: J. C. Miller, Oak Ridge National Laboratory. Sponsor: ORNL and DOE/OHER.

U.S. DOE Environmental Restoration Risk Assessment Workshop, Oak Ridge, Tennessee, June 1991. Chairperson: R. K. White, Oak Ridge National Laboratory. Sponsor: U.S. DOE Environmental Restoration. 


\section{APPENDIX H. ADVISORY COMMITTEE}

\section{RETIRING MEMBERS:}

Dr. J. Norman Bardsley

Lawrence Livermore National Laboratory

P.O. Box 808, MS L-296

Livermore, California 94550
Dr. A. Welford Castleman

Pennsylvania State University

College of Science

152 Davey Laboratory

University Park, Pennsylvania $168(02$

\section{CURRENT MEMBERS:}

Dr. Eugen Merzbacher

Professor

Department of Physics and Astronomy

University of North Carolina

Chapel Hill, North Carolina 27599

Dr. Genevieve Roessler

Department of Nuclear Engineering Sciences

University of Florida

Gainesville, Florida 32611

Dr. Robert Snyder

Professor and Director

Department of Pharmacology and Toxicology

College of Pharmacy, Busch Campus

Rutgers University

Piscataway, New Jersey 08854

Dr. F. Ward Whicker

Senior Scientist

Savannah Rivel Ecology Laboratory

Drawer E

Aiken, South Carolina 29802
Atomic Physics

Molecular Physics

Health Physics

Radiation Dosimetry

Nuclear Medicine

Toxicology

Risk Analysis

Information Management

Environmertal Transport

Site Characterization 


\section{APPENDIX I. PRESENTATIONS}

Abuaf, P., Norman, D., Hingerty, B., Broyde, S., Grunberger, D., and Patel, D., "NMR and Computational Characterization of Aminofluorene Modified Oligonucleotides," presented at the 81st Annu. Meet, of American Assoc. for Cancer Research, Washington, DC, May 23-26, 1990

Allison, D.P., Jacobson, K.B., Thompson, J.R., Lesniewska, E., Brown, G., Warmack, R.J., and Ferrell, T.L., "Electron Scanning-Tunneling Microscopy of DNA," presented at the Meet. on Scanning Microscopy, Bethesda, MD, May 5-10, 1990)

Allison, D.P., Thompson, J.R., Jacobson, K.B., Warmack, R.J., and Ferrell, T.L., "Scanning Tunneling Microscopy of Macromolecules," presented at the 12th Int. Congress for Electron Microscopy, Seattle, Aug. 12-18, 1990

Allison, D.P., Thompson, J.R., Jacobson, K.B., Warmack, R.J., Carrier, W.L., Larimer, F.W., Woychik, R.P., and Ferrell, T.L., "Scanning Tunneling Microscopy of DNA," presented at the 1st Scanning Tunneling Microscopy Conf., (STM '9()/NANO), Baltimore, July 23-27, 1990

Arakawa, E.T. and Callcott, T.A., "Physics of Solids and Macromolecules," presented at the DOE Contractor's Meet, San Francisco, June 26-28, 1990

Baker, D.A., Eckerman, K.F., and Miller, C.W., "ASCRN - A Screening Program for Airborne Releases of Radionuclides," presented at the 35th Annu. Meet. Health Phys. Soc., Anaheim, CA, June 24-28, 1990

Bast, C.B., Gibson, R.E., Cubbison, C., and DeRosa, C.T., "Less-Than-Lifetime Risk Assessment: Estimation of No-Effect Levels for Nonlethal, Toxic End Points by Analogy to Acute Toxicity," presented at the Meet. on Access and Use of Information Resources in Assessing Health Risks from Chemical Exposure, Oak Ridge, TN, June $27-29,1990$

Berven, B.A., Little, C.A., and Swaja, R.E., "Structuring a Cost-Effective Site Characterization," presented at the 200th Natl. Meet. A.m. Chem. Soc., Washington, DC, Aug. 26-31, 1990

Brown, G.M., Sachleben, R.A., Burchett, K.L., Jacobson, K.B., Larimer, F.W., Woychik, R.P., Foote, R.S., Sloop, F.V., Jacobson, D.A., Arlinghaus, H.F., and Thonnard, N., "Stable Isotope Labels for LNA Sequencing and Mapping," presented at the 199th Natl. Meet. Am. Chem. Soc., Boston, Apr. 22-27, 1990

Brown, M.M., Von Halle, E.S., and Auletta, A.E., "The Ames/Salmonella Microsome Assay for Genotoxicity," presented at the Meet. on Access and Use of Information Resources in Assessing Health Risks from Chemical Exposure, Oak Ridge, TN, June $27-29,1990$

Buckner, M.A., Casson, W.H., and Liu, C.J., "Optimization of the New Combination Personnel Neutron Dosimeter," presented at the 35th Annu. Meet. Health Phys. Soc., Anaheim, CA, June 24-28, 1990 
Buckner, M.A., "Evaluation of the Estublishment of Criteria for the Control of Outdoor Contaminated Areas Based on linterpretation of Current DOE Orders and NRC Reg Guides," presented to Nuclear Engineering 542 Management of Rudioactive Waste, ORAU, Oak Ridge, TN, Apr. 12, 1990

Buckner, M.A., "Dosimetry Applications Research-..The Role of the Health Physics Research Reactor in Radiation Biology Studies and Radiation Fundamentals," presented to Harrison Chilhowee Baptist Academy Binlogy Class, Knoxville, TN, May 16,1990

Buckner, M.A., "Dosimetry Applications Research-- The Role of the Health Physics Research Reactor in Nuclear Physics and Detection Studies and Radiation Fundamentals," presented to Harrison Chilhowee Baptist Academy Physics Class, Knoxville, TN, May 16, 1990

Buckner, M.A., "The Development of the Oracle Bubble Dosimeter Data Base, and Initial Analysis; Where Do We Go from Here? " presented to the Bubble Dosimeter Working Group, Las Vegas, June 22, 1990

Carman, H.S., Jr., Klots, C.E., and Compton, R.N., "Charge-Exchange Studies Between Highly Excited Atoms and Ultracold Molecules and Clusters," presented at the 23rd DOE Radiobiological and Chemical Physics Contractors' Meet., Berkeley, CA, June $25-29,1990$

Carman, H.S., Jr., "Multiphoton Excitation, Ionization, and Reactions Involving Alkali Atoms," presented at the 5th Gordon Research Conf, on Multiphoton Processes, New London, NH, June 11-15, 1990

Casson, W.H., Sims, C.S., Murakami, H., and Liu, C.J., "Result of ORNL's 14th Personnel Dosimeter Intercomparison Study," presented at the 35th Annu. Meet. Health Phys. Soc., Anaheim, CA, June 24-28, 1990

Caton, G.M. and Joy, S.E., "Hypertext System Demonstration: Information on the Symposium and BEIA," presented at the Symp. on Access and Use of Information Resources in Assessing Health Risks from Chemical Exposure, Oak Ridge, TN, June $27-29,1990$

Caton, G.M., Houlberg, L.M., Langston, M.E., and Wyrick, J.M., "Biomedical and Environmental Information Analysis Section Communication Resources: Printed and Electronic," presented at the Symp. on Access and Use of Information Resources in Assessing Health Risks from Chemical Exposure, Oak Ridge, TN, June 27-29, 1990

Chen, C.H., McCann, M.P., and Phillips, R.C., "Laser Surface Interaction of High-T Superconductors Advances in Material Science and Applications of High Temperature Superconductors," presented at the NASA Goddard Space Flight Center, Greenbelt, MD, Apr. 2-6, 1990

Chen, C.H., "Kr81 Counting for Nuclear Waste Sites," presented at "רe DOE Workshop on Real-Time Subsurface Monitoring of Groundwater, Dallas, Apr. 17-18, 1990 
Chen, C.H., "Laser Applications to Analytical Chemistry and Superconductors," presented at a Seminar, Chemistry Dep., Univ, of Alabama, Huntsville, May 18, 1990

Chen, C.H., Phillips, R.C., and McCann, M.P., "Laser Applications on High-T Superconductors," presented at the 5th Int. Symp. on Resonance Ionization Spectroscopy and Its Applications, RIS '90, Varese, Italy, Sept, 16-21, 1990

Chen, C.H., "Summer School on Nonlinear Optics and Nonlinear Dynamics at the Institute of Atomic and Molecular Sciences," presented at the Meet of Inst. of Atomic and Molecular Sciences on Nonlinear Optics and Nonlinear Dynamics, Talpei, Taiwan, July 29-Aug. 11, 1990

Chen, C.H., Payne, M.G., Allman, S.L., Garrett, W.R., and Phillips, R.C., "Laser Applications to Condensed Phase Kinetics," presented at the 23rd DOE Radiobiological and Chemical Physics Contractors' Meet., Berkeley, CA, June 25-29, 1990

Christophorou, L.G., "Interactions of Slow Electrons with Excited Molecules," presented at the 10th Annu, Meet. of North American Hypothermia Group, New Orleans, Apr. $7-$ 12,1990

Christophorou, L.G. and Faidas, H., "Dielectric-Liquid Pulsed Power Switch," presented. at the 10th Int. Conf. on Conduction and Breakdown in Dielectric Liquids, Grenoble, France, Sept. 10-14, 1990

Christophorou, L.G., Pinnaduwage, L.A., and Bitouni, A.P., "A New Technique for Measurement of Electron Attachment to Short-Lived Electron Attaching Species," presented at the 6th Int. Symp. on Gaseous Dielectrics, Knoxville, TN, Sept. 23-27, 1990

Christophorou, L.G., "Electron-Molecule Interactions," presented at the 23rd DOE Radiobiological and Chemical Physics Contractors' Meet., Berkeley, CA, June 25-29, 1990

Christophorou, L.G., "Interphase and Liquid State Physics," presented at the 23rd DOE Radiobiological and Chemical Physics Contractors' Meet., Berkeley, CA, June 25-29, 1990

Christophorou, L.G., "Radiation Interactions in High-Pressure Gases," presented at the Conf. on Physical and Chemical Mechanisms in Molecular Radiation Biology, Woods Hole, MA, Sept. 3-7, 1990

Christophorou, L.G., Pinnaduwage, L.A., and Bitouni, A.P., "A Technique for the Measurement of Electron Attachment to Short-Lived Excited Species," presented at the 6th Int. Symp. on Gaseous Dielectrics, Knoxville, TN, Sept. 23-27, 1990

Compton, R.N., "Careers in Physics," presented at Career Day at Oak Ridge High School, Oak Ridge, TN, Apr. 3, 1990 
Compton, R.N., Klots, C.E., Carman, H.S., Jr., and Miller, J.C., "Chemical Physics Studies of the Gaseous and Condensed Phases Using Pulsed Lasers," presented at the 23rd DOE Radiobiological and Chemical Physics Contractors' Meet., Berkeley, CA, June 25-29, 1990

Compton, R.N., "Laser Spectroscopy," presented to the Chemistry and Physics Dep., Davidson College, Davidson, NC, Sept. 14, 1990

Cosman, M., Singh, S., Geacintov, N.E., Ibanez, V., Hingerty, B.E., Broyde, S., and Harvey, R.G., "Experimental and Computer Modellng Studies of Sequence-Defined Oligonucleotides Modified with (+) and (-) Anti-Benzo[a]pyrene Diol Epoxide," presented at the 81 st Annu, Meet. of American Assoc, for Cancer Research, Washington, DC, May 23-26, 1990

Crawford, O.H., Turner, J.E., Hamm, R.N, and Ashley, J.C., "Some Comparisons of Skin Dose-Equivalent Calculations Using VARSKIN and the OR.NL Monte Carlo Electron-Transport Code, OREC," presented at the 35th Annu. Meet. Health Phys. Soc., Anaheim, CA, June 24.28, 1990

Danford, G.S., Uppuluri, S.Y., and Holland, F.M., "Environmental Teratology Information Center," presented at the Meet. on Access and Use of Information Resources in Assessing Health Risks from Chemical Exposure, Oak Ridge, TN, June 27-29, 1990

Daniels, S.C., Haas, R.T., Kilgore, D.G., and Miller, K.C., "Biomedical and Environmental Infor retion Analysis Section/Computing Resources," presented at the Meet. on Access and Use of Information Resources in Assessing Health Risks from Chemical Exposure, Oak Ridge, TN, June 27-29, 1990

Datskos, P.G., Christophorou, L.G., and Carter, J.G., "Temperature Dependence of the Dissociative Electron Attachment to $\mathrm{CH}_{3} \mathrm{Cl}$ and $\mathrm{C}_{2} \mathrm{H}_{5} \mathrm{Cl}$," presented at the 6th Int. Symp. on Gaseous Dielectrics, Knoxville, TN, Sept. 23-27, 1990

Dudney, C.S., Wilson, D.L., and Gammage, R.B., "Performance of Radon Mitigation Systems Installed in Houses with Crawlspaces and/or Daylight Basements," presented at the 5th Int. Conf, on Indoor Air Quality and Climate, Indoor Air '90, Toronto, July 29-Aug. 3, 1990

Dudney, C.S., Wilson, D.L., and Gammage, R.B., "Transport Studies of Radon in Limestone Underlying Houses," presented at the 5th Int. Conf. on Indoor Air Quality and Climate, Indoor Air '90, Toronto, July 29-Aug. 3, 1990

Easterly, C.E., "Relative Potency as a Means of Evaluating ELF Health Risks," presented at the 6th Int. Symp. on Gaseous Dielectrics, Knoxville, TN, Sept. 24-27, 1990

Easterly, C.E., "Power Line Electromagnetic Field Hazards: History, Myths, and Facts," presented at the Meet. Soc. Risk Anal., East Tennessee Chapter, Knoxville, 'TN, June 7, 1990 
Eckerman, K., Ward, R., Mahathy, M., and Boys, R., "Description of Methods for Assessment of Internal Radiation Dose Used in DOSEXPR'T," presented at the 35th Annu. Meet. Health Phys, Soc., Anaheim, CA, June 24-28, 1990

Emery, M.S., Blatr, M.S., and Nyquist, J.E., "On-Site Method for Acquisition and Analysis of Sensor Data," presented at the SENSORS Expo 90, Chicago, Sept. 11-13, 1990)

England, M.W., Turner, J.E., and Jacobson, K.B., "Metal-Ion Toxicities Relative to Normal Metal-Ion Concentrations in an Organism," presented at the 4th Int. Workshop on QSAR in Environmental Toxicology, Veldhoven, The Netherlands, Sept. 16-20, 1990

Etnier, E.L., Hovatter, P.S., Talmage, S.S., Weaver, R.S., Houlberg, L.M., Ross, R.H., and Muhly, R., "Development of Applicable or Relevant and Appropriate Requirements (ARARs) for Remediation of Hazardous Waste Sites Under Superfund," presented at the Meet. on Access and Use of Information Resources in Assessing Health Risks from Chemical Exposure, Oak Ridge, TN, June 27-29, 1990

Faidas, H., Christophorou, L.G., and McCorkle, D.L., "Electron Transport in Fast Dielectric Liquids at High Applied Electric Fields," presented at the 10th Int. Conf. on Conduction and Breakdown in Dielectric Liquids, Grenoble, France, Sept. 10.14, 1990

Faidas, H., Christophorou, L.G., McCorkle, D.L., and Carter, J.G., "Electron Drift Velocities in Liquid and Gaseous Tetramethylsilane, Neopentane and 2,2,4,4-Tetramethylpentare," presented at the 6th Int. Symp. on Gaseous Dielectrics, Knoxville, TN, Sept. 23-27, 1990

Ferrell, T.L., Goudonnet, J.-P., Reddick, R.C., Sharp, S.H., and Warmack, R.J., "The Photon Scanning Tunneling Microscope," presented at the 1st Scanning T'unneling Microscopy Conf., (STM 90/NANO), Baltimore, July 23-27, 1990

Freeman, S., Sanford, D.G., Hingerty, B.E., Broyde, S., and Krugh, T.R., "Structure of an AAF Modified Duplex Nonamer from High Resolution NMR Spectroscopy and Minimized Potential Energy Calculations," presented at the 81 st Annu. Meet. of American Assoc. for Cancer Research, Washington, DC, May 23-26, 1990

Gailey, P.C. and Easterly, C.E., "Mechanisms of Electromagnetic Tissue," presented at the Interaction Peer-Review Workshop for the Evaluation of the Potential Carcinogenicity of Electromagnetic Fields, Morrisville, NC, June 28, 1990

Gammage, R.B., Dudney, C.S., and Wilson, D.L., "Summertime Radon Elevation in Homes Overlying Karst," presented at the 5th Int. Conf. on Indoor Air Quality and Climate, Indoor Air '90), Toronto, July 29-Aug. 3, 1990

Gammage, R.B., Hanna, W.T., and Painter, P., "Unusual Formaldehyde-Induced Hypersensitivity in Two Schoolgirls," presented at the 5th int. Conf. on Indoor Air Quality and Climate, Indoor Air' '90, Toronto, July 29-Aug. 3, 1990) 
Gammage, R.B. and Haas, J.W., III, "In Situ Groundwater Monitor," presented at the Annu. Meet, of American Industrial Hyglene Assoc., Orlando, FL, May 13-18, 199()

Gammage, R.B., Dudney, C.S., and Wilson, D.L., "Radon Mitigation in Southern Appalachian Homes," presented at the Annu. Meet. of American Industrial Hygiene Assoc., Orlando, FL, May 13-18, 1990

Gammage, R.B., Wilson, D.L., Dudney, C.S., and Saultz, R.J., "Summertime Elevation of 222Rn Levels in Huntsville, Alabama," presented at the Natl. Am. Soc. Civ. Eng, Conf. on Environnental Engineering, Washington, DC, July 9-11, 1990

Ganmage, R.B. and Wilson, D.L., "Performance Experience with Radon Mitigation Systems," presented at the 5th Int. Conf. on Indoor Air Quality and Climate, Indoor Air '90, T'oronto, July 29-Aug. 3, 1990

Gammage, R.B., Wilson, D.L., and Dudney, C.S., "Summertime Elevation of Radon in Southern Appalachian Homes," presented at the 5th Int. Conf., on Indoor Air Quality and Climate, Indoor Air '90, Toronto, July 29-Aug. 3, 1990

Garrett, W'R., Hart, R.C., Datskou, I, and Payne, M.G., "Very Large Multiple Collective Lineshifts Observed in Three-Photon Excitations of Xe," presented at the 21 st Annu. Meet. Am. Phys. Soc., Div. At. Mol. Opt. Phys., Monterey, CA, May 21-23, 1990

Garrett, W.R., "Interference and Very Large Pressure Dependent Shifts in Multiphoton Induced Atomic Transitions," presented at the Jt. Seminar at Harvard Observatory and Harvard Univ., Cambridge, MA, May 16, 1990

Garrett, W.R., "Very L arge Pressure Dependent Shifts in Multiphoton-Induced Atomic Transitions and Hyper-Raman Emissions," presented at the Chemical Physics Semin., ORNL, Oak Ridge, TN, May 14, 1990

Gove, R.M., Richmond, A.A., Welch, M.J., and Rawl, R.R., "Packaging and Transportation Safety Program (PATS) Database," presented at the Meet. on Access and Use of Information Resources in Assessing Health Risks from Chemical Exposure, Oak Ridge, TN, June 27-29, 1990

Griffin, G.D., Ryan, M.S., Kurka, K., Nolan, M.G., Sauers, I., and James, D.R., "Disulfur Decafluoride $\left(\mathrm{S}_{2} \mathrm{~F}_{10}\right)$ : A Review of the Biological Properties and Our Experimental Studies of This Breakdown Product of $\mathrm{SF}_{6}$ " presented at the 6th Int. Symp. on Gaseous Dielectrics, Knoxville, TN, Sept. 27-30, 1990

Haas, J.W., III and Gammage, R.B., "Optical Spectroscopic Screening of Environmental Water Samples," presented at the 199th Annu. Meet. Am. Chem. Soc., Boston, Apr. $22-27,1990$

Haas, J.W., III and Lee, E.Y., "Surface-Enhanced Raman Spectroscopic (SERS) Measurements in the Liquid Phase," presented at the 199th Annu. Meet. Am. Chem. Soc., Boston, Apr. 22-27, 1990 
Hans, J.W., IIl and Gammage, R,B., "DUVAS Fiberscope for In Situ Groundwater Monitoring," presented at the DOE Workshop on Real-Time Subsurface Monitoring of Groundwater, Dallas, Apr, 17-18, 1990

Haas, R.T. and Auletta, A.E., "Gene" Tox Agent Registry File," presented at the Meet, on Access and Use of Information Resources in Assessing Health Risks from Chemical Exposture, Oak Ridge, TN, June 27-29, 1990

Haas, R.T., Davidson, M.C., and Rao, K.S., "Genetic Toxicology Chemical Structure File," presented at the Meet. on Access and Use of Information Resources in Assessing Health Risks from Chemical Exposure, Oak Ridge, TN, June 27-29, 1990

Hamm, R.N., Turner, J.E., and Hamley, S.A., "Cross Sections for Low-Energy Protons and Alpha Particles," presented at the 38th Annu. Meet. Radiat. Res. Soc., New Orleans, Apr. 7-12,1990

Hamm, R.N., Ferrell, T.L., and Warmack, R.J., "Liquid and Submicron Physics," presented at the 23rd DOE Radioblological and Chemical Physics Contractors' Meet., Berkeley, CA, June 25-29, 1990

Hamm, R.N., Turner, J.E., Ritchie, R.H., Ashley, J.C., Crawford, O.H., and Klots, C.E., "Microdosimetry and Biological Modeling," presented at the 23rd DOE Raddobiological and Chemical Physics Contractors' Meet., Berkeley, CA, June 25-29, 1990

Hasan, A., Allred, J.F., and Srivastava, P.C.," Enhanced Uptake of a New Electron Affinic 5-(E- ${ }^{125}$ [] lodopentenyl)thio-4-nitroimidazolenucleoside in Hypoxic Tumors," presented at the 37th Annu. Meet. Soc. Nucl. Med., Washington, DC, June 19-22, 1990

Hattemer-Frey, H.A. and Travis, C.C., "Dioxin Emissions from Municipal Solid Waste Incinerators and the Potential for Human Exposure," presented at the Conf. on Municipal Solid Waste Management: Making Decisions in the Face of Uncertainty, Toronto, Apr. 25-27, 1990

Heckman, C.G., Houlberg, L.M., Langston, M.E., Nikbakht, P.A., Salk, M.S., and Stockstill, J.M., "Environmental Guidance Program: Reference Books and Regulatory Update Table," presented at the Symp. on Access and Use of Information Resources in Assessing Health Risks from Chemical Exposure, Oak Ridge, 'TN, June 27-29, 199()

Hingerty, B.E. and Broyde, S., "Hoogsteen Base Pairs in BPDE Modified DNA," presented at the 1 st Int. Conf. on Electrophoresis, Supercomputing, and the Human Genome, Florida State Univ., Tallahassee, Apr. 10-13, 1990)

Hingerty, B.E. and Broyde, S., "Prediction of DNA Structure from Sequence," presented at the 1st Int. Conf. on Electrophoresis, Supercomputing, and the Human Genome, Florida State Univ., Tallahassee, Apr, 10-13, 1990

Hingerty, B.E., Broyde, S., and Shapiro, R., "Predicting Structures of DNA and Carcinogen-Modified DNA by Build-Up Techniques," presented at the 1 st Int. Conf. on Electrophoresis, Supercomputing, and the Human Genome, Florida State Univ., Tallahassee, Apr. 10-13, 1990 
Hoeschele, J.D., Turner, J.E., and England, M.W., "Inorganic Concepts Relevant to Metal Binding, Activity, ana Toxicity in a Biological System," presented at the 4th Int. Workshop on QSAR in Environmental Toxicology, Veldhoven, The Netherlands, Sept. 16-20, 1990

Hovatter, P.S., Gibson, R.E., and Muhly, R., "Selection of Indicator Chemicals at Hazardous Waste Sites," presented at the Meet. on Access and Use of Information Resources in Accessing Health Risks from Chemical Exposure, Oak Ridge, TN, June 27-29, 1990

Hubner, S.M., Kline, B.W., Lu, P.-Y., Pierce, L.B., and Crawl, J.R., "Material Safety Data Sheets for Hazard Communication," presented at the Meet. on Access and Use of Information Resources in Assessing Health Risks from Chemical Exposure, Oak Ridge, TN, June 27-29, 1990

Jacobson, K.B., Arlinghaus, H.F., Thonnard, N., Foote, R.S., Larimer, F.W., Woychik, R.P., Sachleben, R.A., Brown, G.M., Sloop, F.V., and England, M.W., "A Multiplex Method for DNA Sequencing Using Stable Isotopes," presented at the 2nd Conf. on Genome Sequencing, Hilton Head, SC, Sept. 30-Oct. 3, 1990

Jones, T.D., "Bone Marrow Lethality," presented at the Technology Transfer to U.S. Military, Alexandria, VA, Sept. 20, 1990

Kairemo, K.J.A., Kestila, M.S., Korhola, O.A., Hiltunen, J.V., Svahn, R.I., Knapp, F.F., Jr., and Brihaye, C., "Determination of Kidney Perfusion Using Ultra-Short Lived IR-191m as a Tracer," presented at the World Federation of Nuclear Medicine and Biology, Montreal, Aug. 27-31, 1990

Kaye, S.V., "Welcome Address - Access and Use of Information Resources in Assessing Health Risks from Chemical Exposure," presented at the Meet. on Access and Use of Information Resources in Assessing Health Risks from Chemical Exposure, Oak Ridge, TN, June 27-29, 1990

Kerr, G.D., "Neutron Quality Factor," presented at the 35th Annu. Meet. Health Phys. Soc., Anaheim, CA, June 24-28, 1990

Kinser, H.B. and Crawford, O.H., "Integrals in the Complex Kohn Variational Calculation for Electron Scattering by a Screened Coulomb Potential," presented at the Meet. of Georgia Academy of Science, Macon, May 5, 1990

Klots, C.E., "Thermal Kinetics in a Finite Heat Bath," presented at the 11 th Int. Symp. on Gas Kinetics, Assisi, Italy, Sept. 2-7, 1990

Klots, C.E., "Systematics of Evaporation," presented at the 5th Int. Symp. on Small Particles, Konstanz, Federal Republic of Germany, Sept. 10-14, 1990

Klots, C.E., "Kinetic Isotope Effects in Molecular Clusters," presented at the Gordon Conf. on Molecular and Ionic Clusters, Volterra, Italy, Sept. 2-7, 1990 
Kocher, D.C., "Classification and L isposal of Radioactive Wastes -- History and Legal and Regulatory Requirements," presented at the 35th Annu. Meet. Health Phys. Soc., Anaheim, CA, June 24-28, 1990

Kropp, J., Knapp, F.F., Jr., Ambrose, K.R., Visser, F., Biersack, H.-J., and Blystone, S.L., "Release of an Unexpected Myocardial Metabolite of Radioiodinated 15-(p-Iodophenyl)-3-R,S-Methylpentadecanoic Acid (BMIPP) from Isolated Rat Hearts and Canine Hearts In Vivo," presented at the 37th Annu. Meet. Soc. Nucl. Med., Washingion, DC, June 19-22, 1990

Kropp, I., Knapp, F.F., Jr., Ambrose, K.R., Assmann, T., Urmetz, S., Nissen, H.P., and Biersack, H.J., "Metabolites of IPPA, BMIPP, and DMIPP Fatty Acids in Rat Hearts," presented at the European Association of Nuclear Medicine, Amsterdam, May 20-24, 1990

Land, M.D., "Identifying Contaminants of Concern," presented at the Agency for Toxic Substances and Disease Registry (ATSDR) Workshop, Atlanta, Apr. 10-12, 1990

Land, M.D., "Public Health Implications for the Health Division," presented at the Agency for Toxic Substances and Disease Registry (ATSDR) Workshop, Atlanta, Apr. 10-12, 1990

Land, M.D. and Miller, D., "Site Information for the Health Assessment," presented at the Arency for Toxic Substances and Disease Registry (ATSDR) Workshop, Atlanta, Apr. $10-12,1990$

Land, M.D. and Miller, D., "Case Study at the Buffalo Creek Industrial Site," presented at the Agency for Toxic Substances and Disease Registry (ATSDR) Workshop, Atlanta, Apr. 10-12, 1990

Land, M.D., "Soil Exposure Pathways," presented at the Agency for Toxic Substances and Disease Registry (ATSDR) Workshop, Atlanta, Apr. 10-12, 1990

Lee, T.W., McPherson, D.W., Callahan, A.P., Rice, D.E., Ting, G., and Knapp, F.F., Jr., "A Simple Colorimetric Method for Determination of the Specific Activity of Spallation-Produced Copper-67 (Cu-67) Using the Bis-( $\mathrm{N}^{4}$ methyl)Thiosemicarbazone (TSC) Derivative of Phenylglyoxal," presented at the 8th Int. Symp. on Radiopharmaceutical Chemistry, Princeton, NJ, June 24-29, 1990

Light, E., Gammage, R.B., Hansen, D.L., and Johnson, L., "Resolution of Indoor Air Quality Complaints," presented at the Professional Development Course No. 15, Orlando, FL, May 13-18, 1990

Little, C.A., "Plutonium Isotopic Ratios in Samples from Rocky Flats Grassland," presented at the Workshop on Possible Differences in Biological Availability of Isotopes of $\mathrm{Pu}$, Las Vegas, Aug. 28-29, 1990

Malling, H.V. and Wassom, J.S., "Information Resources and the Correlation of Response Patterns Between Biological End Points," presented at the Meet. on Access and Use of Information Resources in Assessing Health Risks from Cnemical Exposure, Oak Ridge, TN, June 27-29, 1990 
Mansfield, B.K., Adamson, A.E., Haas, R.T., Kilgore, D.G., Mayes, M.D., Owens, E.T., Wyrick, J.M., and Yust, L.N., "Human Genome Management Information System," presented at the Meet. on Access and Use of Information Resources in Assessing Health Risks from Chemical Exposure, Oak Ridge, TN, June 27-29, 1990

Mansfield, B.K., Adamson, A.E., Casey, D.K., Kilgore, D.G., Mayes, M.D., Owens, E.T., Wassom, J.S., Wyrick, J.M., and Yust, L.N., "Human Genome Management Information System," presented at the 2nd Conf. on Genome Sequencing, Hilton Head, SC, Sept. 30-Oct. 3, 1990

Mavournin, K.H., Blakey, D.H., Cimino, M.C., Salamone, M.F., and Heddle, J.A., "The In Vivo Micronucleus Assay in Mammalian Bone Marrow and Peripheral Blood," presented at the Meet. on Access and Use of Information Resources in Assessing Health Risks from Chemical Exposure, Oak Ridge, TN, June 27-29, 1990

McPherson, D.W., "Chemistry and Nuclear Medicine," presented at the Visiting 'ndustrial Scientist and Engineer Program, Berea College, Berea, KY, Apr. 9, 1990

Miller, D.B., "The Role of Pathways Analysis in the Health Assessment," presented at the Agency for Toxic Substances and Disease Registry (ATSDR) Workshop, Atlanta, Apr. $10-12,1990$

Miller, J.C. and Smith, D.B., "Resonance Ionization Spectroscopy of Molecular Clusters Using Picosecond Lasers," presented at the 5th Int. Symp. on Resonance Ionization Spectroscopy and Its Applications, RIS '90, Varese, Italy, Sept. 16-21, 1990

Miller, J.C. and Smith, D.B., "Picosecond Multiphoton Ionization of Atomic and Molecular Clisters," presented at the 5th Int. Conf. on Multiphoton Processes, ICOMP V, Paris, Sept. 24-28, 1990

Miller, K.C., Haas, R.T., Kilgore, D.G., and Pfuderer, H.A., "Application of Expert Systems to the Areas of Health, Safety, and Environmental Accountability," presented at the Meet. on Access and Use of Information Resources in Assessing Health Risks from Chemical Exposure, Oak Ridge, TN, June 27-29, 1990

Miller, P.D., "Risk Assessment and PCB Incineration," presented at the DOE High School Honors Program, ORNL, Cak Ridge, TN, July 13, 1990

Mirzadeh, S., Brechbiel, M.W., and Gansow, O.A., "Radiometal Labeling of Immunoproteins: A Study of the Covalent Attachment of SCN-Bzl-DTPA Ligands to Immunoglobulin," presented at the 8th Int. Symp. on Radiopharmaceutical Chemistry, Princeton, NJ, June 24-29, 1990

Mirzadeh, S., Brechbiel, M.W., and Gansow, O.A., "Radiometal Labeling of Immunoproteins: Covalent Attachment of SCN-Bzl-DTPA Ligands to Immunoglobulin," presented at the 8th Int. Symp. on Radiopharmaceutical Chemistry, Princeton, NJ, June 24-28, 1990

Moss, O.R. and Eckerman, K.F., "Proposed NCRP Lung Model: Geometric Basis for Estimating Absorbed Dose," presented at the 3rd Int. Workshop on Respiratory Tract Dosimetry, Albuquerque, NM, July 1-3, 1990 
Nyquist, J.E. and Blair, M.S., "An Automated Locating and Data Logging System for Geophysical Surveys," presented at the 4th Natl. Outdoor Action Conf., Las Vegas, May 14-17, 1990

Nyquist, J.E. and Blair, M.S., "An Automatic Locating and Data Logging System for Radiological Walkover Surveys," presented at the 31st Annu. Meet. of Inst. for Nuclear Materials Management, Los Angeles, July 15-18, 1990

Olthoff, J.K., Van Brunt, R.J., Herron, J.T., Sauers, I., and Harman, G., "Catalytic Decomposition of $\mathrm{S}_{2} \mathrm{~F}_{10}$ and Its Implications on Sampling and Detection from $\mathrm{SF}_{6-}$ Insulated Equipment," presented at the Inst. Electr. Electron. Eng. Int, Symp. on Electrical Insulation, Toronto, June 3-6, 1990

Owen, P.T., "An Overview of Remedial Action Technical Information Support Activities Funded by the U.S. Department of Energy's Office of Environmental Restoration," presented at th. 2 DOE Remedial Action Program Conf., Albuquerque, NM, Apr. 16-19, 1990

Owens, E.T., Vaughan, T.O., Stack, H.F., Jackson, M.A., Kavlock, R.J., and Waters, M.D., "Graphical Activity Profiles in Genetic Toxicology and Teratology," presented at the Meet. on Access and Use of Information Resources in Assessing Health Risks from Chemical Exposure, Oak Ridge, TN, June 27-29, 1990

Panjehpour, M., Vo-Dinh, T., Overholt, B.F., and Pawel, M.D., "A Long Frosted Probe for Interstitial Photodynamic Therapy," presented at the 10th Annu. Meet. of North American Hypothermia Group, New Orleans, Apr. 7-12, 1990

Payne, M.G., Garrett, W.R., Hart, R.C., and Datskou, I., "Large Collective Lamb Shifts in High Pressure Noble Gases," presented at the 5th Int. Symp. on Resonance Ionization Spectroscopy and Its Applications, RIS '90, Varese, Italy, Sept. 16-21, 1990

Payne, M.G., Garrett, W.R., Hart, R.C., Datskou, I., and Wray, J., "Large Collective Lamb Shifts in High Pressure Nob. " Gases," presented at the 5th Int. Symp. on Resonance Ionization Spectroscopy and Its Applications, RIS '90, Varese, Italy, Sept. $16-21,1990$

Pfuderer, H.A., Crutcher, J.W., Stokes, D.M., and Miller, K.C., "Air Permits Expert Systems," presented at the Martin Marietta Software Symp., Oak Ridge, TN, Sept. 11, 1990

Pinnaduwage, L.A. and Christophorou, L.G., "Enhanced Electron Attachment to Molecular Superexcited States," presented at the Meet. Am. Phys. Soc., Washington, DC, Apr. 16-19, 1990

Reddick, R.C., Sharp, S.H., Goudonnet, J.P., Warmack, R.J., and Ferrell, T.L., "Photon Scanning Tunneling Microscopy," presented at the Meet. on Scanning Microscopy, Bethesda, MD, May 5-10, 1990 
Reddick, R.C., Warmack, R.J., Ferrell, T.L., Cites, J., Sanghadasa, M.F.M., and Sung, C.C., "Essential Physics for PSTM of Rough Surfaces," presented at the 1st Scanning Tunneling Microscopy Conf. (STM '90/NANO), Baltimore, July 23-27, 1990

Reisman, D.J., DeRosa, C.T., Francis, M.W., Miller, I.C., Stafford, R.S., Francis, A.A., Bast, C.B., and Lu, P.-Y., "Chemical Unit Record Estimates," presented at the Meet. on Access and Use of Information Resources in Assessing Health Risks from Chemical Exposure, Oak Ridge, TN, June 27-29, 1990

Ritchie, R.H., Ashley, J.C., and Crawford, O.H., "Surface and Transport Physics," presented at the 23rd DOE Radiobiological and Chemical Physics Contractors' Meet., Berkeley, CA, June 25-29, 1990

Ritchie, R.H., Echenique, P.M., and Flores, F., "Image Potential Effects for Low- and High-Energy Electrons," presented at the European Conf. on Surface Science, Salamanca, Spain, Sept. 1990

Ross, R.H., Bast, C.L., Daugherty, M.W., Davidson, K.A., Faust, R.A., Francis, A.A., Hovatter, P.S., Opresko, D.M., Talmage, S.S., Young, R.A., DeRosa, C.T., Choudhury, H., Cubbison, C., Smith, B.G., and Cogliano, V.J., "Chemical Hazard Assessment," presented at the Meet. on Access and Use of Information Resources in Assessing Health Risks from Chemical Exposure, Oak Ridge, TN, June 27-29, 1990

Ryman, J.C., Ward, R.C., Eckerman, K.F., and Fearon, T., "The PALGAM Monte Carlo Photon Transport Code Using Polygon Slice Human Phantom Models," presented at the Meet. on Monte Carlo Methods for Neutron and Photon Transport Calculations, Budapest, Sept. 25-28, 1990

Sauers, I., Harman, G., Olthoff, J., and Van Brunt, R.J., " $\mathrm{S}_{2} \mathrm{~F}_{10}$ Formation by Electrical Discharges in $\mathrm{SF}_{6}$ : Comparison of Spark and Corona," presented at the 6th Int. Symp. on Gaseous Dielectrics, Knoxville, TN, Sept. 23-27, 1990

Sauers, I., "Neutral and Charged Species in $\mathrm{SF}_{6}$ Discharges," presented at the Seminar, Tennessee Technological Univ., Cookeville, TN, Apr. 10, 1990

Sauers, I. and Harman, G., "A Mass Spectrometer Study of Ionization in $\mathrm{SF}_{6}$ Corona: Influence of Water and Neutral By-Products," presented at the 6th Int. Symp. on Gaseous Dielectrics, Knoxville, TN, Sept. 27-30, 1990

Shea, M.J. and Compton, R.N., "Ion Ejection from Metals Irradiated with Pulsed Laser Light: Thermal and Nonthermal Components," presented at the 17 th Int. Quantum Electronics Conf., Anaheim, CA, May 21-25, 1990

Sims, C.S., "Review and Modification of ANSI N13.11, the Dosimeter Performance Test Standard," presented at the 35th Annu. Meet. Health Phys. Soc., Anaheim, CA, June 24-28, 1990

Sims, C.S., "Modification of the Dosimeter Performance Standard ANSI N 13.11," presented at the 9th Panasonic Thermoluminescent Dosimeter (TLD) Int. Symp., Keystone, CO, June 17-23, 1990 
Sims, C.S., "Health Physics Research Reactor: A Reactor of Value to DOE Operational Health Physics Activities," presented at DOE, Washington, DC, June 6, 1990

Sims, C.S., "The Health Physics Research Reactor: A Test Facility of Value to Military Interests," presented to the Defense Nuclear Agency, Washington, DC, June 7, 1990

Sims, C.S., "The Health Physics Research Reactor: A Test Facility of Value to Military Interests," presented at Redstone Arsenal, Huntsville, AL, June 12, 1990

Sims, C.S. and Casson, W.H., "RADCAL: The New Radiation Calibration Laboratory at ORNL," presented at DOE Headquarters, Germantown, MD, June 6, 1990

Sims, C.S., "Radiation Source Control: A Category II TSA Issue," presented at the Meet. of Radiation Source Development Team, Oak Ridge, TN, July 23, 1990

Sims, C.S., "Radiation Source Control: A Category II TSA Issue," presented at the Meet. of Five Plant Radiation Protection Committee, Paducah, KY, July 24, 1990

Sims, C.S., "Health Physics Research Reactor - A Test Facility of Value to Military Interests," presented at a Meeting, 'J.S. Air Force, Norton Air Force Base, El Segundo, CA, Sept. 14, 1990

Slusher, K.G., Francis, M.W., and Miller, I.C., "Toxicology Information Response Center," presented at the Meet. on Access and Use of Information Resources in Assessing Health Risks from Chemical Exposure, Oak Ridge, TN, June 27-29, 1990

Smith, M.C., Holch, W.E., and Turner, J.E., "Nearest-Neighbor Distributions of Free Radicals Produced Within Charged-Particle Tracks in Liquid Water," presented at the 38th Annu. Meet. Radiat. Res. Soc., New Orleans, Apr. 7-12, 1990

Srivastava, P.C., Lambert, C.R., Allred, J.F., Kennel, S.J., Hasan, A., and Buchsbaum, D.J., "I-125 Labeled Azomycin Acyclonuclecside: Design and Synthesis of an Attractive Misonidazole Analogue for Imaging Hypoxia," presented at the 37th Annu. Meet. Soc. Nucl. Med., Washington, DC, Jine 19-22, 1990

Srivastava, P.C., Allred, J.F., Lambert, C.R., and Kennel, S.J., "No-Carrier-Added Preparation of a New Radioiodinated Maleimide as a Potentially Attractive Radioimmunoconjugator with Low In Vivo Deiodination," presented at the 37th Annu. Meet. Soc. Nucl. Med., Washington, DC, June 19-22, 1990

Srivastava, P.C., Hasan, A., and Buchsbaum, D.J., "Iodoazomycin Acyclonucleoside: A Potential SPECT Imaging Agent with High Tumor Uptake," presented at the 8th Int. Symp. on Radiopharmaceutical Chemistry, Princeton, NJ, June 24-29, 1990

Srivastava, P.C., Buchsbaum, D.J., and Hasan, A., "Design, Synthesis, and Tumor Specificity of Azomycin Ribo- and Acyclonucleosides," presented at the 9th Int. Round Table Conf. on Nucleosides and Nucleotides and Their Biological Applications, Uppsala, Sweden, July 30, 1990 
Srivastava, P.C., Hasan, A., and Buchsbaum, D.J., "Iodoazomycin Acyclonucleoside: A Potential SPECT Imaging Agent with High Tumor Uptake," presented at the 8th Int. Symp. on Radiopharmaceutical Chemistry, Princeton, NJ, June 24-29, 1990

Srivastava, P.C., Lambert, C.R., Allred, J.F., Kennel, S.J., Hasan, A., and Buchsbaum, D.J., "I-125 Labeled Azomycin Acyclonucleoside: Design and Synthesis of an Attractive Misonidazole Analogue for Imaging Hypoxia," presented at the 37th Annu. Meet. Soc. Nucl. Med., Washington, DC, June 19-22, 1990

Srivastava, P.C., Allred, J.F., Lambert, C.R., and Kennel, S.J., "No-Carrier Added Preparation of a New Radioiodinated Maleimide as a Potentially Attractive Radioimmunoconjugator with Low In Vivo Deiodination," presented at the 37th Annu. Meet. Soc. Nucl. Med., Washington, DC, June 19-22, 1990

Stafford, R.S. and Lu, P.-Y., "Animal Testing Alternatives - A Selected Annotated Bibliography," presented at the Meet. on Access and Use of Information Resources in Assessing Health Risks from Chemical Exposure, Oak Ridge, TN, June 27-29, 1990

Thompson, J.R., Allison, D.P., Jacobson, K.B., Warmack, R.J., and Ferrell, T.L., "Scanning Tunneling Microscopy of Tobacco Mosaic Virus," presented at the 1st Scanning Tunneling Microscopy Conf. (STM '90/NANO), Baltimore, July 23-27, 1990

Travis, C.C., "Multi-Environmental Pollutant Assessment System (MEPAS) and Current Scoring of ORR Sites on the National Ranking System," presented at the Meet. Remedial Action Program (RAP), Chattanooga, TN, Apr. 3, 1990

Travis, C.C., Land, M.D., Miller, D.B., Shireman, J., White, R.K., and Zygmont, N.J., "Health Assessment Format, Guidelines and Methodology," presented at the Agency for Toxic Substances and Disease Registry (ATSDR) Workshop, Atlanta, Apr. 10-12, 1990

Travis, C.C. and Doty, C.B., "Remedial Action Decision Process," presented at the ORNL Life Sciences Symp., Gatlinburg, TN, May 24, 1990

Travis, C.C., "PCB Risk Assessment for Kansas City DOE," presented at the Meet. with EPA and Allied Chemical on Risk Assessment, Kansas City, KS, June 10-11, 1990

Travis, C.C. and Doty, C.B., "Risk Management at Hazardous Waste Sites," presented at the 200th Natl. Meet. Arn. Chem. Soc., Washington, DC, Aug. 26-31, 1990

Turner, J.E. and Fry, R.J.M., "On Dose-Response Modeling of High-LET Radiation Carcinogenesis and Life Shortening," presented at the 38th Annu. Meet. Radiat. Res. Soc., New Orleans, Apr. 7-12, 1990

Turner, J.E., Bolch, W.E., Crawford, O.H., Hamm, R.N., Yoshida, H., and Jacobson, K.B., "Calculated Chemical Yields from X-Irradiation of Glygylglycine in OxygenFree Aqueous Solution. II. Late Chemical Yields," presented at the 38th Annu. Meet. Radiat. Res. Soc., New Orleans, Apr. 7-12, 1990 
Turner, J.E., Hamley, S.A., and Bogard, J.S., "Calculation of Dose and Dose-Averaged LET as Functions of Depth in Water from Alpha Disc Sources," presented at the 35th Annu. Meet. Health Phys. Soc., Anaheim, CA, June 24-28 1990

Turner, J.E., Hingerty, B.E., England, M.W., and Jacobson, X.,B., "Calculated Distortions Induced by Metal-Ion Binding to Simple Oligonucleotide Systems: Implications for Toxicity," presented at the 4th Int. Workshop on $0 S A R$ in Environmental Toxicology, Veldhoven, The Netherlands, Sept. 16-20, 1990

Turner, J.E., England, M.W., Jacobson, K.B., and Hingerty, B.E. "Studies of Physical Parameters for Health Protection from Chemical Pollutants," presented at the 23rd DOE Radiobiological and Chemical Physics Contractors' Meet., Berkeley, CA, June 25-29, 1990

Turner, J.E., "Introduction to Microdosimetry," presented at the Three pay Course on Radiopharmaceutical Internal Dose Calculation Techniques, ORAUl Oak Ridge, TN, May 2, 1990

Turner, J.E., "Microdosimetry," presented at the 35th Annu. Meet. Health Phys. Soc., Anaheim, CA, June 24-28, 1990

Uziel, M.S., Floyd, L.M., and Crutcher, J.W., "Radiological Site Characterization Surveys and Data Analyses," presented at the Meet. on Access and Use of Information Resources in Assessing Health Risks from Chemical Exposure, Oak Ridge, TN, June $27-29,1990$

Visser, F.C., Sloof, G.W., Comans, E., Eenige van, M.J., and Knapp, F.F., "Metabolism of Radioiodinated 17-Iodoheptadecanoic Acid in the Normal and Ischemic Dog Heart," presented at the 12th Congress Eur. Soc. Cardiol., Stockholm, Sept. 1418,1990

Visser, F.C., Sluof, G.W., Eenige van, M.J., and Knapp, F.F., "Radioiodinated Heptadecanoic Acid, Phenylpentadecanoic Acid and Dimethylphenylpentadecanoic Acid in the Normal Canine Heart. Comparison of Uptake, Oxidation and Lipid Distribution," presented at the 12th Congress Eur. Soc. Cardiol., Stockholm, Sept. 14-18, 1990

Vo-Dinh, T. and Griffin, G.D., "Antibody-Based Fiberoptics Sensors for In-Situ Monitoring," presented at the DOE Workshop on Real-Time Subsurface Monitoring of Groundwater, Dallas, Apr. 17-18, 1990

Vo-Dinh, T., "Immunofluorescence and Raman Fiberoptics Chemical Sensors," presented at the Centre d'Etudes Nucleaire (CEN), Fontenay-Aux-Roses, France, June 1, 1990

Vo-Dinh, T., "Advances in Luminescence and Raman Spectroscopy for Chemical and Biological Analysis," presented at the Universit of Bordeaux, Bordeaux, France, June 5, 1990

Vo-Dinh, T., Stokes, D.L., Miller, G.H., Bello, J.M., Wachter, E.A., Haas, J.W., and James, D.R., "Surface-Enhanced Raman Spectroscopy for In Situ and Remote Sensing," presented at the Soc. Photo-Opt. Instrum. Eng. Symp. on Optical and Optoelectronic Applied Science and Engineering, San Diego, July 8-13, 1990 
Wachter, E.A., Haas, J.W., III, James, D.R., Gammage, R.B., Ferrell, T.L., and Vo-Dinh, T., "Advances in Surface-Enhanced Raman Spectroscopy for Hazardous Waste Monitoring," presented at the Soc. Photo-Opt. Instrum. Eng. Symp. on Optical and Optoelectronic Applied Science and Engineering, San Diego, July 8-13, 1990

Wachter, E.A., Ferrell, T.L., Gammage, R.B., Vo-Dinh, T., Haas, J.W., III, and James, D.R., "Advances in Surface-Enhanced Raman Spectroscopy for Applications in Real-Time Subsurface Monitoring," presented at the DOE Workshop on Real-Time Subsurface Monitoring of Groundwater, Dallas, Apr. 17-18, 1990

Warmack, R.J., Reddick, R.C., Sharp, S.L., Ferrell, T.L., Tsai, D.P., and Jackson, H.E., "PSTM Studies of Quasistatic Fields," presented at the 1st Scanning Tunneling Microscopy Conf. (STM '90/NANO), Baltimore, July 23-27, 1990

Wassom, J.S., "Evolution of Toxicology Information Systems," presented at the Symp. on Access and Use of Information Resources in Assessing Health Risks from Chemical Exposure, Oak Ridge, TN, June 27-29, 1990

White, D., "Health/Risk Communication - A Reciprocal Process," presented at the Agency for Toxic Substances and Disease Registry (ATSDR) Workshop, Atlanta, Apr. 10-12, 1990

White, R.K., "Understanding the Health Assessment Methodology," presented at the Agency for Toxic Substances and Disease Registry (ATSDR) Workshop, Atlanta, Apr. 10-12, 1990

White, R.K., "Human Health Risk Assessment at Hazardous Waste Sites," presented at the Countdown 2000: An Environmental Odyssey, Charlotte, NC, June 26, 1990

Whitfield, B.L., "The Rodent Dominant Lethal Assay," presented at the Meet. on Access and Use of Information Resources in Assessing Health Risks from Chemical Exposure, Oak Ridge, TN, June 27-29, 1990

Wilson, D.L., Dudney, C.S., Gammage, R.B., and Matthews, T.G., "Study Design for Phase I of the U.S. Navy Radon Assessment and Mitigation Program," presented at the 5th Int. Conf. on Indoor Air Quality and Climate, Indoor Air '90, Toronto, July 29Aug. 3, 1990

Wilson, D.L., Haas, J.W., III, and Gammage, R.B., "Soil Gas Survey at a Complex LUST Site," presented at the Annu. Meet. of American Industrial Hygiene Assoc., Orlando, FL, May 13-18, 1990

Wilson, D.L., Dudney, C.S., and Gammage, R.B., "U.S. Navy Radon Assessment and Mitigation Program," presented at the 5th Int. Conf. on Indoor Air Quality and Climate, Indoor Air '90, Toronto, July 29-Aug. 3, 1990

Wunderlich, R.K., Moore, M.A., Garrett, W.R., and Payne, M.G., "AC-Stark Shifts in Gas Phase Nonlinear Optical Processes," presented at the Int. Quantum Electronics Conf., IQEC '90, Anaheim, CA, May 21-25, 1990 
Wyrick, J.M. and Wyrick, L.H., "Elements of Design - Using Design to Communicate Your Message (Panel Discussion on Newsletter)," presented at the Meet. Soc. Tech. Commun., East Tennessee Chapter, ORAU, Oak Ridge, TN, Sept. 25, 1990

Yoshida, H., Bolch, W.E., Turner, J.E., Jacobson, K.B., and Garrison, W.M., "Measurement of Products from X-Irradiated ('vicylglycine in Oxygen-Free Solutions," presented at the 8th Annu. Meet. Radiat. Res. Soc., New Orleans, Apr. 7-12, 1990

Young, R.A., Lu, P.Y., Francis, M.W., Ross, R.H., Jepson, G.W., and Fisher, J.W., "Toxicology Guide for Installation Restoration Program Application," presented at the Meet. on Access and Use of Information Resources in Assessing Health Risks from Chemical Exposure, Oak Ridge, TN, June 27-29, 1990 


\section{APPENDIX J. PUBLICATIONS}

Abuaf, P., Norman, D., Hingerty, B., Broyde, S., Grunberger, D., and Patel, D., "NMR and Computational Characterization of Aminofluorene Modified Oligonucleotides," Abstract Booklet, Meet. of American Assoc. for Cancer Research, Washington, DC, May 23-26, 1990 (1990)

Alarie, J.P., Sepaniak, M.J., and Vo-Dinh, T., "Evaluation of Antibody Immobilization Techniques for Fiber Optic-based Fluoroimmunosensing," Anal. Chim. Acta 229, $169-76(1990)$

Allison, D.P., Thompson, J.R., Jacobson, K.B., Warmack, R.J., and Ferrell, T.L., "Scanning Tunneling Microscopy and Spectroscopy of Plasmid DNA," Scanning Microsc. 4, 517-22 (1990)

Allison, D.P., Thompson, J.R., Jacobson, K.B., Warmack, R.J., and Ferrell, T.L., "Scanning Tunneling Microscopy of Macromolecules," Proc, 12th Int. Congress for Electron Microscopy, Seattle, San Francisco Press, Inc., San Francisco, 1990, p. 110

Allison, L.J., Hunsaker, C.T., Cushman, R.M., White, T.W., and Draves, J.D., Environmental Atlas of the Iowa-Kansas-Missouri-Nebraska Climate-Change Study Region, ORNL/CDIAC-33

Arakawa, E.T. and Inagaki, T., "Liquid Mercury (Hg)," Handbook of Optical Consultants of Solids II, Academic Press, Inc., 1991, V. 2, pp. 461-68

Arakawa, E.T., Callcott, T.A., and Chang, Y.-C., "Optical Properties of Beryllium," Bull. Am. Phys. Soc. 35, 351 (1990)

Arakawa, E.T., Callcott, T.A., and Chang, Y.C., The Optical Properties of Beryllium, ORNL/OMIS-89/9

Arnau, A., Penalba, M., Echenique, P.M., Flores, F., and Ritchie, R.H. "Stopping Power for Helium in Aluminum," Phys. Rev. Lett. 65, 1024-27 (1990)

Ashley, J.C., "Interaction of Low-Energy Electrons and Positrons with Condensed Matter: Stopping Powers and Inelastic Mean Free Paths from Optical Data," Proc. 12th Werner Brandt Int. Conf. on Penetration of Charged Particles in Matter, San Sebastian, Spain, Sept. 4-7, 1989, CONF-8909210, 1990, pp. 551-71

Ashley, J.C., "Energy Loss Rate and Inelastic Mean Free Path of Low-Energy Electrons and Positrons in Condensed Matter," J. Electron Spectrosc. Related Phenom. 50, 323-34 (1990)

Ashley, J.C., "Inelastic Interactions of Electrons and Positrons with Solids," Proc. U.S.Japan Workshop on Atomic Collisions in Solids, Honolulu, Feb. 2-9, 1990, CONF900276,1990, p. 12 
Ashley, J.C., Proceedings of U.S.-Japan Workshop on Atomic Collisions in Solids, Honolulu, February 2-9, 1990, Oak Ridge National Laboratory, CONF-900276, 1990

Ashley, J.C., "Energy-Loss Probabilities for Electrons, Positrons, and Protons in Condensed Matter," J. Appl. Phys. 69, 674-78 (1991)

Ashley, J.C., "Optical-Data Model for the Stopping Power of Condensed Matter for Protons and Antiprotons," J. Phys.: Condens. Matter 3, 2741-53 (1991.)

Ashley, J.C., Turner, J.E., Crawford, O.H., Hamm, R.N., Reaves, K.L., and McMahan, K.L., Technical Background for Shallow (Skin) Dose Equivalent Evaluations, ORNL/TM-11705

Bajic, S.J., Compton, R.N., Tang, X., and Lambropoulos, P., "Resonantly Fnhanced Multiphoton-Ionization Photoelectron Spectroscopy of Krypton and Xenon: Experiment and Theory," Phys. Rev. A 44, 2102-12 (1991)

Barkenbus, B.D., Carter, R.J., Dobson, J.E., Easterly, C.E., Ogle, P.S., and VanCleave, A.K., Environmental Protection for Hazardous Materials Incidents, ORNL/TM-11421

Basbas, G., Howie, A., and Ritchie, R.H., "Collective Aspects of Charged Particle Track Structure," Proc. 12th Werner Brandt Int. Conf. on Penetration of Charged Particles in Matter, San Sebastian, Spain, CONF-8909210, 1990, pp. 651-72

Beal, D., Bock, J., Hatmaker, T., Zolyniak, J., Goddard, P., Kucsmas, D., Land, M.L., Landguth, D.C., McGinn, C.W., and Miller, D., Phase 2 Remedial Investigation Work Plan for the K-1070-CID Classified Burial Ground at the Oak Ridge K-25 Site, Oak Ridge, Tennessee, Vol. 1: History, Environmental Characterization, and Project Sco., ES/ER-9/V1\&D1

Belcher, G.D. and Hattemer-Frey, H.A., "A Program for Calculating Health Risks from Hazardous Waste Incineration," Risk Anal. 10, 185-88 (1990)

Belcher, G.D. and Travis, C.C., "An Uncertainty Analysis of Food Chain Exposures to Pollutants Emitted from Municipal Waste Combustors," Health Effects of Municipal Waste Incineration, CRC Press, Boca Raton, FL, 1991, pp. 211-35

Bello, J.M. and Vo-Dinh, T., "Surface-Enhanced Raman Scattering Fiber-Optic Sensor," Appl. Spectrosc. 44, 63-69 (1990)

Bello, J.M., Narayanan, V.A., Stokes, D.L., and Vo-Dinh, T., "Fiber-Optic Remote Sensor for In Situ Surface-Enhanced Raman Scattering Analysis," Anal. Chem. 62, 2437-41 (1990)

Berven, B.A., Little, C.A., and Blair, M.S., "A Method to Automate Radiological Surveys: The Ultra Sonic Ranging and Data System," Health Phys. 60, 367-73 (1991) 
Berven, B.A., Nyquist, J.E., Blair, M.S., Little, C.A., and Gammage, R.B., "Automation of Geophysical Surveys Used in Assessment of Hazardous Waste," Proc. 28th Hanford Life Sciences Symp., Richland, WA, Oct. 16-19,1989, Battelle Press, Columbus, OH, 1990, pp. 67-74

Bohrman, D.E., Uziel, M.S., Landguth, D.C., and Hawthorne, S.W., Work Plan, Health and Safety Plan, and Site Characterization for the Waste Coolant Processing Facility (T-038), ORNL/M-1115

Bohrman, D.E., Landguth, D.C., Hawthorne, S.W., and Uziel, M.S., Work Plan, Health and Safety Plan, and Site Characterization for the Tank 2116-U Site, ORNLM-1114

Bohrman, D.E.. Uziel, M.S., Landguth, D.C., and Hawthorne, S.W., Work Plan, Health and Safety Plan, and Site Characterization for the Rust Spoil Area (D-106), ORNL/M-1209

Bohrman, D.E., Uziel, M.S., Burman, S.N., and Hawthorne, S.W., Work Plan, Health and Safety Plan, and Quality Assurance Project Plan for K-1420 Waste Area Grouping, ORNL/M-1364

Bolch, W.E., Turner, J.E., Yoshida, H., Jacobson, K.B., Wright, H.A., and Hamm, R.N., "Monte Carlo Calculations of Free Ammonia Production in Deoxygenated Solutions of Glycylglycine Irradiated by X-Rays and ${ }^{60} \mathrm{Co}$ Gamma-Rays," Radiat. Res. 121, 248-56 (1990)

Bolch, W.E., Turner, J.E., Yoshida, H., Jacobson, K.B., Hamm, R.N., and Wright, H.A., "Monte Carlo Simulation of Free Radical Attack to Biomolecules Irradiated in Aqueous Solution," Radiat. Prot. Dosim. 31, $43-46$ (1990)

Borges, H.T., Glauert, H.P., Peterson, R.E., Pitot, H.C.W., and Robertson, L.W., "Lack of Promoting Activity of Perfluorodecanoic Acid (PFDA) in 2-Stage Hepatocarcinogenesis," The Toxicologist 11, 678 (1991)

Borges, T., Robertson, L.W., and Glauert, H.P., "Perfluorodecanoic Acid (PFDA) Inhibits the Bifunctional Protein of Peroxisomal B-Oxidation In Vitro," FASEB J.5, A-145 (1991)

Brothers, R.A., Preliminary Health Assessment for Williams Pipe Line Company, Twelfth Street Terminal, Sioux Falls, Minnehaha County, South Dakota, ORNL/M1778

Broyde, S., Hingerty, B.E., Shapiro, R., and Norman, D., "Unusual Hydrogen Bonding Patterns in AF and AAF Modified DNA," Nitroarenes: Occurrence, Metabolism, and Biological Impact, Plenum Press, New York and London, 1990, pp. 113-23

Broyde, S., Hingerty, B.E., Xu, R., O'Handley, S.F., and Krugh, T.R., "Static and Animated Molecular Views if a Tumorigenic Chernical Bound to DNA," Chapter 4, Proc. Ist Energy Research l'ower Supercomputer Users Symp., Gaithersburg, MD, May 21, 1991, CONF-910's202, DOE, 1991 
Burman, S.N., Uziel, M.S., and Hatmaker, T.L., Work Plan, Health and Safety Plan, and Quality Assurance Project Plan for the K-1220 Underground Storage Tanks at the Oak Ridge K-25 Site, Oak Ridge, Tennes.ee, ORNL/M-1502

Burman, S.N., Uziel, M.S., and Hatmaker, T.L., Work Plan, Health and Safety Plan, and Quality Assurance Project Plan for the K-1220 Underground Storage Tanks at the Oak Ridge K-25 Site, Oak Ridge, Tennessee, ORNL/M-1523

Calcott, T.A., Zhang, C.H., Ederer, D.L., Mueller, D.R., Rubensson, J.E., and Arakawa, E.T., "The Photon Excitation of Soft X-Ray Emission Spectra," Nucl. Instrum. Methods Phys. Res. A 291, 13-18 (1990)

Carman, H.S., Jr., Klots, C.E., and Compton, R.N., "Isotope-Dependent Rate Constants for $\mathrm{CS}_{2}$ Formation in Cs (ns,nd) $+\mathrm{CS}_{2}$ Collisions, J. Chem. Phys. 92 5751-52 (1990)

Carrier, R.F., Tiner, P.F., Roberts, D.A., Rodriguez, R.E., and Williams, J.K., Results of a Radiological Scoping Survey of Building 9204-1 at the Y-12 Plant, Oak Ridge, Tennessee, ORNL/ER-38

Caton, G.M., Radon Research Notes, Vol. 1, Issue No. 1, April 1990, ORNL/M-1087

Caton, G.M. and Wyrick, J.M., Ceramic Technology Newsletter, No. 26, JanuaryMarch 1990, ORNL/M-1112

Caton, G.M. and Wyrick, J.M., Ceramic Technology Newsletter, No. 27, April-June 1990, ORNL/M-1221

Caton, G.M., Radon Research Notes, Vol. 1, Issue 2, August 1990, ORNL/M-1235

Caton, G.M., Radon Research Notes, No. 3, February 1991, ORNL/M-1369

Caton, G.M. and Wyrick, J.M., Ceramic Technology Newsletter, No. 30, JanuaryMarch 1991, ORNL/M-1409

Caton, G.M., Radon Research Notes, No. 5, July 1991, ORNL/M-1571

Caton, G.M. and Wyrick, J.M., Ceramic Technology Newsletter, No. 32, JulySeptember 1991, ORNL/M-1701

Caton, G.M. and Wyrick, J.M., ORNL Ceramic Technology Newsletter, No. 31, AprilJune 1991, ORNL/M-1566

Charalambidis, D., Lyras, A., Lambropoulos, P., Tang, X., Bajic, S., and Compton, R.N., "Collisional Relaxation of the $6 s[3 / 2]^{0}{ }_{1}$ and $6 s^{\prime}[1 / 2]^{0}{ }_{1} \mathrm{M}_{\mathrm{j}}$ Levels of Xenon Using Resonantly Enhanced Multiphoton Ionization," Phys. Rev. A 41, 1457-65 (1990) 
Chavarria, D.E., Conklin, N.G., Davidson, J.R., Egidi, P.V., Ertel, D.B., Espegren, M.L., Foster, D.S., Kearl, P.M., Knott, R.R., Krall, B.J., Meredith, R.L., Pierce, G.A., Retolaza, C.D., Rice, J.A., Roemer, E.K., Smuin, D.R., Wilson, M.J., and Witt, D.A., Pollutant Assessments Group Procedures Manual, ORNL-6645

Chen, C.H., Payne, M.G., Hurst, G.S., Kramer, S.D., Allman, S.L., and Phillips, R.C., "Isotopically Selective Counting of Atoms and Molecules Using Resonance Ionization Spectroscopy," Laser and Mass Spectrometry, Oxford University Press, 1990 , v. 1 , pp. $1-36$

Chen, C.H., Phillips, R.C., and McCann, M.P., "Reply to the Comment on "Observation of Trapped $\mathrm{O}_{2}$ in High- $\mathrm{T}_{\mathrm{c}}$ Metal Oxide Superconductors," Phys, Rev, B 41, 4783 (1990)

Chen, C.H. and McCann, M.P., "Two-Photon-Induced Chemical Reactions in Liquids," Appl. Spectrosc. 44, 115-17 (1990)

Chen, C.H., "Development of a Real Time Monitor for Superconductive Thin Film Preparation," Proc. Soc. Photo-Opt. Instrum. Eng. Symp. on Surface and Interface Analysis of Microelectronic Materials Processing and Growth, Santa Clara, CA, Oct. 12-13,1989, Int. Soc. Opt. En., Vol. 1186, pp. 71-78

Chen, C.H., McCann, M.P., and Phillips, R.C., "Laser Surface Interactions of High-T Superconductors," Proc. Advances in Material Science and Applications of High Temperature Superconductors Conf., AMSAHTS '90, NASA Goddard Space Center, Greenbelt, MD, Apr. 2-6,1990, NASA Publ., 1991, v. 1, pp. 271-78

Chen, C.H., Murphy, T.M., and Phillips, R.C., "Laser Desorption Mass Spectra of $\mathrm{YBa}_{2} \mathrm{Cu}_{3} \mathrm{O}_{7-\mathrm{x}}, "$ Appl. Phys. Lett. 57, 937-39 (1990)

Chen, C.H., Phillips, R.C., and McCann, M.P., "Laser Applications for High-T Superconductors," Proc. Sth Int. Symp. on Resonance Ionization Spectroscopy and Its Applications, RIS '90, Varese, Italy, Sept.16-21,1990, Adam Hilger, Ltd., 1990, v. 114 , pp. $425-29$

Chen, C.H. and Phillips, R.C., "Desorption Spectra of Laser Ablation of $\mathrm{Bi}_{2} \mathrm{Sr}_{2} \mathrm{CaCu}_{2} \mathrm{O}_{8+\mathrm{x}}, " J$. Appl. Phys. 70, 4643-45 (1991)

Cheng, Y.-F., Piccard, R.D., and Vo-Dinh, T., "Charge-Coupled Device Fluorescence Detection for Capillary Zone Electrophoresis (CCD-CZE)," Appl. Spectrosc. 44, 755-65 (1990)

Chidambariah, V., Travis, C.C., Trabalka, J.R., and Thomas, J.K., "A Toxicity Index of Prioritization of Inactive Underground Storage Tanks," J. Hazardous Mater. 27, 327-37 (1991)

Choudhury, H., Davidson, K.A., Cubbison, C., Peirano, W.B., and DeRosa, C., "Alternate Approach to Develop Reportable Quantities (RQs) for Lead Compounds," The Toxicologist 11, 196 (1991) 
Christophorou, L.G., "Electron Collisions in Gas Switches," Nonequilibrium Processes in Partially Ionized Gases, Plenum Press, New York, 1990, pp. 291-309

Christophorou, L.G., Faidas, H., and McCorkle, D.L., "Iltrafast and Ultrasensitive Dielectric Liquids/Mixtures: Basic Measurements and Applications," Nonequilibrium Effects in Ion and Electron Transport, Plenum Press, New York, 1990, pp. 313-28

Christophorou, L.G. and Pinnaduwage, L.A., "Basic Physics of Gaseous Dielectrics," IEEE Trans, Electr. Insul. 25, 55-74 (1990)

Christophorou, L.G. and Faidas, H., "Dielectric-Liquid Pulsed Power S vitch," Proc. 10th Int. Conf. on Conduction and Breakdown in Liquids, Grenoble, France, Sept. 10-14,1990, CNRS, France, 1990, pp. 454-58

Christophorou, L.G., Pinnaduwage, L.A., and Bitouni, A.P., "A Technique for the Measurement of Electron Attachment to Short-Lived Excited Species," Proc. 6th Int. Symp. on Gaseous Dielectrics, Knoxville, TN, Sept.23-27, 1990, Plenum Press, New York, 1991, pp. 9-17

Cosman, M., Singh, S., Geacintov, N.E., Ibanez, V., Hingerty, B.E., Broyde, S., and Harvey, R.G., "Experimental and Computer Modeling Studies of Sequence-Defined Oligonucleotides Modified with (+) and (-) Anti-Benzo[a]pyrene Diol Epoxide," Abstract Booklet, Meet. American Assoc. for Cancer Research, Washington, DC, May 23-26, 1990 (1990)

Cottrell, W.L and Carrier, R.F., Results of the Radiological Survey of the Carpenter Steel Facility, Reading, Pennsylvania, ORNL/RASA-89/3

Cottrell, W.D. and Carrier, R.F., Results of the Radiological Survey at the Granite City Steel Facility, Granite City, Illinois, ORNL/RASA-89/10

Cottrell, W.D. and Carrier, R.F., Radiological Survey of the Former Aeroprojects Facility, West Chester, Pennsylvania, ORNL/RASA-90/5

Cottrell, W.D., Witt, D.A., Rodriguez, R.E., and Carrier, R.F., Results of Mobile Gamma Scanning Activities in Tonawanda, New York, ORNL/RASA-90/6

Cottrell, W.D. and Williams, J.K., Preliminary Results of the Radiological Survey at the Former Dow, Chemical Company Site, Madison, Illinois, ORNL/TM-11552

Cottrell, W.D., Quillen, J.L., and Crutcher, J.W., Results of the Radiological Survey at the Former Ore Storage Site, Palmerton, Pennsylvania (PP001), ORNL/TM-11218

Cottrell, W.D., Crutcher, J.W., and Quillen, J.L., Results of the Radiological Survey at the Former Heppenstall Company Site, 4620 Hatfield Street, Pittsburgh,

Pennsylvania, ORNL/RASA-89/19

Cottrell, W.D., Foley, R.D., and Floyd, L.M., Results of the Radiological Survey at the Jessop Steel Company Site, 500 Green Street, Washington, Pennsylvania (JSP001), ORNL/RASA-89/20 
Coursey, B.M., Calhoun, J.M., Cessna, J., Hoppes, D.D., Schima, F.J., Unterweger, M.P., Golas, D.B., Callahan, A.P., Mirzadeh, S., and Knapp, F.F., Jr., "Assay of the Eluent from the Alumina-Based Tungsten-188-Rhenium-188 Generator," Radioact. Radioisot. 3, 38-49 (1990)

Crawford, O.H., "Directional Effects on the Motion of Swift Ions in Anisotropic Media," Phys. Rev. A 42, 1390-95 (1990)

Crawford, O.H., "A Model for Cluster-Impact Fusion," Proc. U.S.-Japan Workshop on Atomic Collisions in Solids, Honolulu, Feb. 2-9, 1990, CONF-900276, 1990, p. 15

Crawford, O.H., "Bending of Swift Ion Beams by Graphite Foils," Proc. U.S.-Japan Workshop on Atomic Collisions in Solids, Honolulu, Feb. 2-9, 1990, CONF 900276,1990 , p. 5

Crawford, O.H., "Line Shapes in Resonant Coherent Excitation: Theory," Proc. U.S.Japan Workshop on Atomic Collisions in Solids, Honolulu, Feb. 2-9,1990, CONF900276,1990, p. 10

Crawford, O.H., "Thoughts on Cold Fusion," Proc. U.S.-Japan Workshop on Atomic Collisions in Solids, Honolulu, Feb. 2-9,1990, CONF-900276, 1990, p. 16

Crawford, O.H., Turner, J.E. Hamm, R.N., and Ashley, J.C., "Effects of the TissueAir Interface in Calculations of Beta-Particle Skin Dose at at Depth of 70 Mu-m," Health Phys. 61, 641-45 (1991)

Cronk, T.A. and Kearl, P.M., "The Relationship of Advective Transport in a Borehole to That in the Surrounding Aquifer - Theoretical and Experimental Results," EOS (Washington) 71, 716(1990)

Cronk, T.A., Smuin, D.R., and Schlosser, R.M., Preliminary Site Characterization Summary and Engineering Evaluation/Cost Analysis for Site 2-New Fuel Farm, Naval Air Station Fallon, Fallon, Nevada, ORNL/TM-11886

Crutcher, J.W. and Wilson, M.J., Results of the Independent Verification of Radiological Remedial Action at 165 North 1st West Street, Monticello, Utah (MS00014), ORNL/RASA.89/26

Crutcher, J.W. and Wilson, M.J., Results of the Independent Verification of Radiological Remedial Action at 217 South 2nd East Street, Monticello, Utah (MS00097), ORNL/RASA-89/25

Crutcher, J.W. and Wilson, M.J., Results of the Independent Verification of Radiological Remedial Action at 280 South 3rd East Street, Monticello, Utah (MS00099), ORNL/RASA-89/24

Crutcher, J.W. and Wilson, M.J., Results of the Independent Verification of Radiological Remedial Action at 281 East 3rd South Street, Monticello, Utah (MS00138), ORNL/RASA-89/23 
Crutcher, J.W. and Wilson, M.J., Results of the Independent Verification of Radiological Remedial Action at 416 South Main Street, Monticello, Utah (MSO0150), ORNL/RASA-89/22

Crutcher, J.W. and Wilson, M.J., Results of the Independent Verification of Radiological Remedial Action at 433 South 2nd East Street, Monticello, Utah (MSO0103), ORNL/RASA-89/2.1

Cuellar, L.E., Compton, R.N., Carman, H.S., Jr., and Feigerle, C.S., "Photoelectron Angular Distributions for ns $(n=8-12)$ Subshells of Cesium: Relativistic Effects," Phys. Rev. Lett. 65, 163-66 (1990)

Cuellar, L.E., Feigerle, C.S., Carman, H.S., and Compton, R.N., "Circular Dichroism Effects on the Photoelectron Angular Distributions for the 7/ $\mathrm{P}_{3 / 2}$ State of Cesium," Phys. Rev. A 43, 6437-40 (1991)

Datskos, P.G., Christophorou, L.G., and Carter, J.G., "Temperature-Enhanced Electron Attachment to $\mathrm{CH}_{3} \mathrm{Cl}$," Chem. Phys. Lett. 168, 324-29 (1990)

Datskos, P.G., Christophorou, L.G., and Carter, J.G., "Temperature Dependence of the Dissociative Electron Attachment to $\mathrm{CH}_{3} \mathrm{Cl}$ and $\mathrm{C}_{2} \mathrm{H}_{5} \mathrm{Cl}$," Proc. 6th Int. Symp. on Gaseous Dielectrics, Knoxville, TN, Sept. 23-27, 1990, Plenum Press, New York, 1991, pp. 35-52

Davidson, K.A., Hovatter, P.S., Ross, R.H., DeRosa, C., and Smith, B.G., "Toxic Effects and Risk Assessment for Boron and Compounds," The Toxicologist 10, 352 (1990)

Dawson, P., Haas, J.W., III, Alexander, K.B., Thompson, J., and Ferrell, T.L., "Surface Enhanced Raman Scattering from Mildly Roughened Surfaces: Variation of Signal with Metal Grain Size," Surf. Sci. 250, L383-88 (1991)

Ding, J., Steiner, T., Zabel, V., Hingerty, B.E., Mason, S.A., and Saenger, W., "Neutron Diffraction Study of the Hydrogen Bonding in Partially Deuterated GammaCyclodextrin $15.7 \mathrm{D}_{2} \mathrm{O}$ at $\mathrm{T}=110 \mathrm{~K}, " \mathrm{~J}$. Am. Chem. Soc. 113, $8081-89$ (1991)

Doty, C.B. and Travis, C.C., "Is EPA's National Priorities List Correct?" Environ. Sci. Technol. 24, 1778-80 (1990)

Doty, C.B. and Travis, C.C., The Effectiveness of Groundwater Pumping as a Restoration Technology, ORNL/TM-11866

Doty, C.B., Crotwell, A.G., and Travis, C.C., Cost Growth for Treatment Technologies at NPL Sites, ORNL/TM-11849

Dudney, C.S., Hawthorne, A.R., Wallace, R.G., and Reed, R.P., "Radon-222, ${ }^{222 R n}$ Progeny, and ${ }^{220}$ Rn Progeny Levels in 70 Houses," Health Phys. 58, 297-311 (1990) 
Dudney, C.S., Wilson, D.L., Saultz, R.J., and Matthews, T.G., "One-Year Follow-Up Study of Performance of Radon Mitigation Systems Installed in Tennessee Valley Houses," Proc. Int. Symp. on Radon and Radon Reduction Technology, Atlanta, Feb. 19-23, 1990 (1991), v. 1, pp. 7-59--7-71

Easterly, C.E., "Relative Potency Can Be Used to Evaluate ELF Health Risks," Proc. Am. Stat. Assoc. Conf. on Radiation and Health, Copper Mountain, CO, July 9-13, 1989 (1990), pp. 67-71

Echenique, P.M., Manson, J.R., and Ritchie, R.H., "Cluster Impact Fusion," Phys. Rev, Lett. 64, 1413-16 (1990)

Echenique, P.M., Ritchie, R.H., and Manson, J.R., "Cluster-Impact Fusion," Proc. U.S.-Japan Workshop on Atomic Collisions in Solids, Honolulu, Feb. 2-9, 1990, CONF-900276, 1990, p. 14

Echenique, P.M., Flores, F., and Ritchie, R.H., "Dynamic Screening of Ions in Condensed Matter," Solid State Physics, Academic Press, Inc., 1990, v. 43, pp. 229-308

Eckerman, K.F. and Hawthorne, A.R., "ORNL's Impact on Radiation Protection Guidance," ORNL Rev. 23, 64-75 (1990)

Emery, M.S., Blair, M.S., and Nyquist, J.E., "On-Site Method for Acquisition and Analysis of Sensor Data," Proc. SENSORS Expo 90, Chicago, Sept. 11-13, 1990 (1990), pp. 107A-1--7

England, M.W., Faust, J.B., Wilkerson, E.K., and Jacobson, K.B., "Strontium Toxicity in Drosophila melanogaster," Toxicology 65, 251-57 (1991)

England, M.W., Turner, J.E., and Jacobson, K.B., "Metal-Ion Toxicities Relative to Normal Metal-Ion Concentrations in an Organism," Abstract Book, 4th Int. Workshop on QSAR in Environmental Toxicology, Veldhoven, The Netherlands, Sept. 16-20, 1990 (1990), p. 115

Espinoza, G. and Gammage, R.B., "Radon Levels Inside Residences in Mexico City," Radiat. Prot. Dosim. 34, 183-85 (1990)

Etnier, E.L. and Hartley, W.R., "Comparison of Water Quality Criterion and Lifetime Health Advisory for Hexahydro-1,3,5-trinitro-1,3,5-triazine (RDX)," Regul.

Toxicol. Pharmacol. 11, 118-22 (1990)

Etnier, E.L. and Weaver, R.S., Applicable or Relevant and Appropriate Requirements (ARARs) for WAG-1, Oak Ridge National Laboratory, ORNL/ER-2\&D1

Etnier, E.L. and Weaver, R.S., Afplicable or Relevant and Appropriate Requirements (ARARs) for WAG-6, Oak Ridge National Laboratory, ORNL/ER-1\&D1

Etnier, E.L. and Weaver, R.S., Applicable or Relevant and Appropriate Requirements (ARARs) for Remedial Action at the Oak Ridge Reservation-A Compendium of Major Environmental Laws, ES/ER/TM-1 
Etnier, E.L., Implementation of the Natural Resource Damage Assessment Rule Workshop Summary Interim Notification Policy, ES/ER/TM-24

Faidas, H., Christophorou, L.G., McCorkle, D.L., and Carter, J.G., "Electron Drift Velocities and Electron Mobilities in Fast Room Temperature Dielectric Liquids and Their Corresponding Vapors,". Nucl. Instrum. Methods Phys. Res. A 294, 575-82 (1990)

Faidas, H., Christophorou, L.G., and McCorkle, D.L., "Electron Transport in Fast Dielectric Liquids at High Applied Electric Fields," Proc, 10th Int. Conf. on Conduction and Breakdown in Dielectric Liquids, Grenoble, France, Sept. 10-14, 1990, IEEE, 1990, pp. 34-38

Ferrell, T.L., Goudonnet, J.P., Reddick, R.C., Sharp, S.L., and Warmack, R.J., "The Photon Scanning Tunneling Microscope," J. Vac. Sci. Technol. B 9, 525-30 (1991)

Fields, D.E., Cottrell, W.D., and Blalock, L., Doses to Railroad Workers Exposed to Shipments of High-Level Radioactive Waste, ORNL-6591

Flores, F., Arnau, A., Echenique, P.M., and Ritchie, R.H., "Stopping Power for Protons in Al for the Whole Range of Velocities," Proc. 12th Werner Brandt Int. Conf. on Penetration of Charged Particles in Matter, San Sebastian, Spain, Sept. 4-7, 1989, CONF-8909210, 1990, pp. 69.84

Foley, R.D. and Crutcher, J.W., Results of the Preliminary Radiological Survey at the Former Diamond Magnesium Company Site, Luckey, Ohio (DMLO01), ORNL/TM11182

Foley, R.D. and Floyd, L.M., Results of the Radiological Survey at Diebold Safe Company, 1550 Grand Boulevard, Hamilton, Ohio (H0001), ORNL/RASA-88/59

Foley, R.D. and Carrier, R.F., Results of the Radiological Survey at State Route 17 \& Becker Avenue, Maywood, New Jersey (MJ033), ORNL/RASA-88/36

Foley, R.D. and Floyd, L.M., Results of the Radiological Survey at 14 Saint Ann Place, Rochelle Park, New Jersey (MJ032), ORNL/RASA-88/34

Foley, R.D. and Floyd, L.M., Results of the Radiological Survey at West Hunter Avenue Firehall, Maywood, New.Jersey (MJ027), ORNL/RASA-88/32

Foley, R.D. and Floyd, L.M., Results of the Radiological Survey at 80 State Highway 46, Lodi, New Jersey (LJ092), ORNL/RASA-88/91

Foley, R.D. and Floyd, L.M., Preliminary Site Survey Report for the Uniroyal Chemical Company, Formerly the Diamond Magnesium Company, 720 Fairport-Nursery Road Painesville, Ohio (DMP00I), ORNL/TM-11119

Foley, R.D. and Carrier, R.F., Results of the Radiological Surveys of 20 BoroughOwned Properties, Maywood, New Jersey (MJ050), ORNL/RASA-90/4 
Foley, R.D. and Floyd, L.M., Preliminary Site Survey Keport of the Copperweld Steel Company, 4000 Mahoning Avenue, NW, Warren, Ohio (CWO001), ORNL/RASA$90 / 2$

Foley, R.D., Cottrell, W.D., and Crutcher, J.W., Results of the Radiological Survey at Conviber Inc., 644 Garfield Street, Springdale, Pennsylvania (CVP00?), ORNL/RASA-89/18

Forsberg, C.W., Croff, A.G., and Kocher, D.C., Historical Perspective, Economic Analysis, and Regulatory Analysis of the Impacts of Waste PartitioningTransmutation on the Disposal of Radioactive Wastes, ORNL/TM-11650

Franken, P.R., Dobbeleir, A.A., Ham, H.R., Ranquin, R., Lieber, S., Van Den Branden, F., Van Den Heuvel, P., Brihaye, C., Guillaume, M., Knapp, F.F., Jr., and Vandevivere, J., "Discrepancy Between Myocardial Perfusion and Regional Wall Motion at Rest and During Exercise in Patients with Coronary Artery Disease," Nucl. Med. Commun. 12, 473-84 (1991)

Gammage, R.B., "Exposure to Formaldehyde in Indoor Air," Risk Anal. 10, 77-83 (1990)

Gammage, R.B. and Haas, J.W., III, "In Situ Groundwater Monitor," Abstract Book, Annu. Meet. of American Industrial Hygiene Assoc., Orlando, FL, May 13-18, 1990 (1990), p. 213

Gammage, R.B., Wilson, D.L., Dudney, C.S., and Matthews, T.G., "First-Phase Study Design for the U.S. Navy Radon Assessment and Mitigation Program (NAVRAMP)," Proc. Int. Symp. on Radon and Radon Reduction Technology, Atlanta, Feb. 19-23, 1990, EPA, 1990, v. 2, p. B-IV-4

Gammage, R.B. and Wilson, D.L., "Performance Experience with Radon Mitigation Systems," Indoor Air '90: 5th Int. Conf. on Indoor Air Quality and Climate, Toronto, July 29-Aug. 3, 1990, Inglewood Printing, Aurora, Canada, 1990, v. 3, pp. 507-12

Gammage, R.B. and Wilson, D.L., "Summertime Elevation of Radon in Southern Appalachian Homes," Indoor Air '90: 5th Int. Conf. on Indoor Air Quality and Climate, Toronto, July 29-Aug. 3, 1990, Inglewood Printing, Aurora, Canada, 1990, v. 3, pp. 451-55

Gammage, R.B., Dudney, C.S., Wilson, D.L., and Saultz, R.J., "Transport Studies of Radon in Limestone Underlying Houses," Indoor Air '90: Sth Int. Conf. on Indoor Air Quality and Climate, Toronto, July 29-Aug. 3, 1990, Inglewood Printing, Aurora, Canada, 1990 , v. 3, pp. 65-70

Gammage, R.B., Hanna, W.T., and Painter, P.B., "Unusual Formaldehyde-Induced Hypersensitivity in Two Schoolgirls," Proc. Indoor Air "90: 5th Int. Conf. on Indoor Air Quality and Climate, Toronto, July 29-Aug. 3, 1990, Inglewood Printing, Aurora, Canada, 1990, pp. 39-42

Gammage, R.B., "Letter to the Editor," Indoor Air Qual. 3, 15 (1990) 
Gammage, R.B., Haas, J.W., III, and Allen, T.M., "Synchronous Fluorescence (SF): A Versatile Field Screening Method for Polynuclear Aromatics in Groundwater," Proc. 2nd Int. Symp, on Field Screening Methods for Hazardous Wastes and Toxic Chemicals, Las Vegas, Feb. 12-14, 1991 (1991), pp. 673-76

Gammage, R.B., Haas, J.W., III, and Allen, T.M., "Screening of Groundwater for Aromatics by Synchronous Fluorescence," Proc. 2nd Int. Symp. on Field Screening Methods for Hazardous Wastes and Toxic Chemicals, Las Vegas, Feb. 12-14, 1991, pp. $673-76$

Gammage, R.B., Wilson, D.L., Dudney, C.S., and Saultz, R.J., "Seasonally Elevated Indoor Radon Caused by Air Movements in Porous Limestone," Abstract Book, American Industrial Hygiene Conf., Salt Lake City, May 18-24, 1991 (1991), p. 65

Gammage, R.B., Dudney, C.S., and Wilson, D.L., "Radon Mitigation in Southern Appalachian Homes," Abstract Book, Annu. Meet. of American Industrial Hygiene Assoc., Orlando, FL, May 13-18, 1990 (1990), p. 18

Garrett, W.R., Hart, R.C., Wray, J.E., Datskou, I., and Payne, M.G., "Large Multiple Collective Line Shifts Observed in Three-Photon Excitations of Xe," Phys. Rev. Leit. 64, 1717-20 (1990)

Garrett, W.R., Hart, R.C., Moore, M.A., Payne, M.G., and Wunderlich, R.K., "Saturation Behavior of Parametric Four-Wave Mixing Due to Two-Photon Interference Effect," Proc. 6th Rochester Conf. on Coherence and Quantum Optics, Univ. of Rochester, Rochester, New York, June 26-28, 1989, Plenum Press, New York, 1990, pp. 389-93

Glass, L.R., Easterly, C.E., Jones, T.D., and Walsh, P.J., "Ranking of Carcinogenic Potency Using a Relative Potency Approach," Arch. Environ. Contam. Toxicol. 21, $169-76(1991)$

Glass, L.R., Jones, T.D., Easterly, C.E., and Walsh, P.J., Use of Short-Term Test Systems for the Prediction of the Hazard Represented by Potential Chemical Carcinogens, ORNL/TM-11413

Glass, L.R., Jones, T.D., Easterly, C.E., and Walsh, P.J., "Use of Short-Term Test Systems for the Prediction of the Hazard Represented by Potential Chemical Carcinogens," Environ. Auditor 2, 1-67 (1991)

Goodman, M.M. and Knapp, F.F., Jr., "Synthesis and Biological Evaluation of (E)-3-C[125I]iodoethenyl-D-allose: A New Strategy for the Preparation of In Vivo Stable Radioiodinated Carboh-jdrates," Nuc Compact, Compact News Nucl. Med. 21, 6469 (1990)

Goudonnet, J.P., Bijeon, J.L., and Warmack, R.J., "Optical Properties of Submicrometer-Size Spheroids Formed on a Graphite Substrate," J. Appl. Phys. 67, 3093-96 (1990) 
Goudonnet, J.P., Bijeon, J.L., Warmack, R.J., and Ferrell, T.L., "Substrate Effects on the Surface-Enhanced Raman Spectrum of Benzoic Acid Adsorbed on Silver Oblate Microparticles," Phys. Rev. B 43, 4605.12 (1991)

Goudonnet, J.P. and Ferrell, T.L., "La Microscopie a Effet T'unnel Photonique," Spectra $2000155,39 \cdots 42(1991)$

Griest, W.H., Stewart, A.J., Tyndall, R.L., Ho, C.-h., and Tan, E., Characterization of Explosives Processing Waste Decomposition Due to Composting, ORNL/TM-11573

Griffin, G.D., Nolan, M.G., Easterly, C.E., Sauers, I., and Votaw, P.C., "Concerning Biological Effects of Spark-Decomposed SF," IEE (Part A) 137(4), 221-27 (1990)

Griffin, G.D., Sepaniak, M.J., Tromberg, B.J., Alarie, J.P., and Vo-Dinh, T., "Antibody-Based Sensor for Polynuclear Aromatic Compounds: A Review of Our Experience," J. Cell. Biochem. (Suppl.) 14B, 365 (1990)

Guella, T., Miller, T.M., Stockdale, J.A.D., Bederson, B., and Vuskovic, L., "Polarizabilities of the Alkali Halide Dimers II," J. Chem. Phys. 94, 6857-61 (1991)

Haas, J.W., III and Gammage, R.B., "DUVAS Fiberscope for In Situ Groundwater Monitoring," Proc. Workshop on DOE Real-Time Subsurface Monitoring of Groundwater, Dallas, Apr. 17-18, 1990, DOE/HWP-62, 1990

Haas, J.W., III, Mathews, T.G., and Gammage, R.B., "In Situ Detection of Toxic Aromatic Compounds in Groundwater Using Fiberoptic UV Spectroscopy," Proc. 2nd Int. Symp. on Field Screening Methods for Hazardous Wastes and Toxic Chemicals, Las Vegas, Feb. 12-14, 1991 (1991), pp. 677-82

Haas, R. and Caton, G., "The NEPA Environmental Review and Compliance Expert System," Proc. INFOTECH '91 DOE Technical Information Meet., Oak Ridge, TN, May 22-23, 1991, CONF-9105153, 1991, pp. 33-40

Hall, S.C., Thate, J., and Landguth, D.C., Work Plan: Quality AssurancelQuality Control Health and Safety Plan for the Site Characterization of K-1070-C/D, ORNL/M-1168

Hall, S.C., Thate, J., and Landguth, D.C., Work Plan: Quality Assurance/Quality Control Health and Safety Plan for the Site Characterization of K-1070-A, ORNL/M1167

Hamm, R.N., Wright, H.A., Turner, J.E., Howell, R.W., Rao, D.V., and Sastry, K.S.R., "Calculations of Auger-Cascade-Induced Reactions with DNA in Aqueous Solution," Proc. 12th Werner Brande Int. Conf. on Penetration of Charged Particles in Matter, San Sebastian, Spain, Sept. 4-7, 1989, CONF-8909210, 1990, pp. 673-80)

Hamm, R.N., Turner, J.E., Jones, T.D., and Preston, R.J., "Calculations of DNA Damage from Photon and Neutron Irradiation," Congress Abstracts, 9th Int. Congress of Radiation Research, Toronto, July 7-12, 1991, Academic Press, Inc., San Diego, 1991, v. 1, p. 406 
Harland, P.W., Carman, H.S., Jr., Phillips, L.F., and Brooks, P.R., "Effects of Molecular Orientation on Electron-Transfer Collisions," J. Phys. Chem. 95, 8137-42 (1991)

Hasan, A., Lambert, C.R., and Srivastava, P.C., "Synthesis and Biological Evaluation of 5-Substituted-4-Nitroimidazole Ribonucleosides," J. Heterocycl. Chem. 3, 1877 83 (1990)

Hattemer-Frey, H.A. and Travis, C.C., "A Perspective on Municipal Waste Combustors as a Source of Environmental Dioxin," Health Effects of Municipal Waste Incineration, CRC Press, Boca Raton, FL, 1991, pp. 327-38

Hattemer-Frey, H.A., Brandt, E.J., and Travis, C.C., "Small-Scale Field T'est of the Genetically Engineered LacZY Marker," Regul. Toxicol. Pharmacol. 11, 253-61 (1990)

Hattemer-Frey, H.A. and Travis, C.C., "Characterizing the Extent of Human Exposure to PCDDs and PCDFs Emitted from a Typical, Modern Municipal Waste Combustor," Health Effects of Municipal Waste Incineration, CRC Press, Boca Raton, FL, 1991, pp. 339-48

Hattemer-Frey, H.A. and Travis, C.C., "Assessing the Extent of Human Exposure Through the Food Chain to Pollutants Emitted from Municipal Solid Waste Incinerators," Health Effects of Municipal Waste Incineration, CRC Press, Boca Raton, FL, 1991, pp. 83-101

Hattemer-Frey, H.A., Travis, C.C., and Land, M.L., "Benzene: Environmental Partitioning and Human Exposure," Environ. Res. 53, 221-32 (1990)

Hattemer-Frey, H.A. and Travis, C.C., "Benzo-a-Pyrene Environmental Partitioning and Human Exposure," Toxicol. Ind. Health 7, 141-57 (1991)

Hawkins, G.T., Houlberg, L.M., Noghrei-Nikbakht, P.A., and Salk, M.S., Environmental Regulatory Update Table - November 1990, ORNL,-6608/R10

Hawkins, G.T., Houlberg, L.M., Noghrei-Nikbakht, P.A., and Salk, M.S., Environmental Regulatory Update Table December 1990, ORNL-6608/R11

Hawkins, G.T., Houlberg, L.M., and Salk, M.S., Environmental Regulatory Update Table - January 1991, ORNL-6658

Hawkins, G.T., Houlberg, L.M., and Salk, M.S., Environmental Regulatory Update Table - Fiebruary 1991, ORNL-6658/R1

Hawkins, G.T., Houlberg, L.M., and Salk, M.S., Environmental Regulatory Update Table - March 1991, ORNL-6658/R2

Hawkins, G.T., Houlberg, L.M., and Salk, M.S., Environmental Regulatory Update Table - April 1991, ORNL-6658/R3 
Heckman, C.G., Houlberg, L.M., Langston, M.E., Nikbakht, P.A., Salk, M.S., and Stockstill, J.M., "Environmental Guidance Program: Reference Books and Regulatory Update Table," Proc. Access and Use of Information Resources in Assessing Health Risks from Chemical Exposure, Oak Ridge, TN, June 27-29, 1990, EPA, p. 35

Hetrick, D.M., Jarabek, A.M., and Travis, C.C., "Sensitivity Analysis for Physiologically Based Pharmacokinetic Models," J. Pharmacokinetics \& Biopharm. 19, 1 -20 (1991)

Hettich, R.L., Compton, R.N., and Ritchie, R.H., "Doubly Charged Negative Ions of Carbon-60," Phys, Rev. Lett. 67, 1242-45 (1991)

Hingerty, B.E. and Broyde, S., "Atomic Resolution Structures of DNA and DNA Modified by Carcinogens," Int. J. Supercomput. Appl. 4, 11-21 (1990)

Hingerty, B.E. and Broyde, S., "Hoogsteen Base Pairs in BPDE Modified DNA," 4 bstract Booklet, 1st Int. Conf. on Electrophoresis, Supercomputing, and the Human Genome, Florida State Univ., Tallahassee, Apr. 10-13, 1990 (1990)

Hingerty, B. F. and Broyde, S., "Prediction of DNA Structure from Sequence," Abstract Booklet, lst Int. Conf. on Electrophoresis, Supercomputing, and the Human Genome, Florida State Univ., Tallahassee, Apr. 10-13, 1990 (1990)

Hingerty, B.E., Broyde, S., and Shapiro, R.," Predicting Structures of DNA and Carcinogen-Modified DNA by Build-Up Techniques," Proc. Ist Int. Conf. on Electrophoresis, Supercomputing, and the Human Genome, Flcu ida State Univ., Tallahassee, Apr. 10-13, 1990, World Scientific Publ., 1991, pp. 96-100

Hoeschele, J.D., Turner, J.E., and England, M.W., "Inorganic Concepts Relevant to Metal Binding, Activity, and Toxicity in a Biological System," Proc. 4th Int. Workshop on QSAR in Environmental Toxicology, Veldhoven, The Netherlands, Sept. 16-20, 1990 (1990), p. 62

Hook, L.A., Voorhees, L.D., Gentry, M.J., Faulkner, M.A., Shaakir-Ali, J.A., Newman, K.A., McCord, R.A., Goins, L.F., and Owens, P.T., Data Base Management Activities for the Remedial Action Program at ORNL: Calendar Year 1989, ORNL/ER-16

Houlberg, L.M., Langston, M.E., Nikbakht, A., and Salk, M.S., Enviromental Regulatory Update Table for December 1989, ORNL-6526/R11

Houlberg, L.M., Langston, M.E., Nikbakht, A., and Salk, M.S., Enviromental Regulatory Update Table - January 1990, ORNL-6608

Houlberg, L.M., Langston, M.E., Nikbakht, A., and Salk, M.S., Enviromental Regulatory Update Table - February 1990, ORNL-6608/R1

Houlberg, L.M., Langston, M.E., Nikbakht, A., and Salk, M.S., Enviromental Regulatory Update Table - March 1990, ORNL-6608/R2 
Houlberg, L.M., Langston, M.E., Nikbakht, A., and Salk, M.S., Enviromental Regulatory Update Table - April 1990, ORNL-6608/R3

Houlberg, L.M., Nikbakht, A., and Salk, M.S., Environmental Regulatory Update Table - May 1990, ORNL-6608/R4

Houlberg, L.M., Nikbakht, A., and Salk, M.S., Environmental Regulatory Update Table, ORNL-6608/R6

Houlberg, L.M., Langston, M.E., Nikbakht, A., and Salk, M.S., Environmental Regulatory Update Table - June 1990, ORNL-6608/R5

Houlberg, L.M., Nikbakht, A., and Salk, M.S., Environmental Regulatory Update Table - August 1990, ORNL-6608/R7

Houlberg, L.M., Nikbakht, A., and Salk, M.S., Environmental Regulatory Update Table - September 1990, ORNL-6608/R8

Houlberg, L.M., Noghrei-Nikbakht, P.A., Salk, M.S., Environmental Regulatory Update Table, October 1990, ORNL-6608/R9

Houlberg, L.M., Nikbakht, A., and Salk, M.S., Environmental Regulatory Update Table - May 1991, ORNL-6658/R4

Houlberg, L.M., Hawkins, G.T., and Salk, M.S., Environmental Regulatory Update Table - June 1991, ORNL-6658/R5

Houlberg, L.M., Hawkins, G.T., and Salk, M.S., Environmental Regulatory Update Table - July 1991, ORNL-6658/R6

Houlberg, L.M., Hawkins, G.T., and Salk, M.S., Environmental Regulatory Update Table - August 1991, ORNL-6658/R7

Houlberg, L.M., Hawkins, G.T., and Salk, M.S., Environmental Regulatory Update Table - September 1991, ORNL-6658/R8

Houlberg, L.M., Hawkins, G.T., and Salk, M.S., Environmental Regulatory Update Table - November 1991, ORNL-6658/R10

Houlberg, L.M., Hawkins, G.T., and Salk, M.S., Environmental Regulatory Update Table - October 1991, ORNL-6658/R9

Huston, T.E. and Turner, J.E., A User's Manual for ALDOSE: A Computer Code for Calculating Absorbed-Dose Rate, Dose-Equivalent Rate, and Dose-Weighted LET as Functions of Depth in Water Irradiated by an Alpha Disc Source, ORNL/TM-11618

Illman, B.L., Anderson, V.E., Warmack, R.J., and Ferrell, T.L., "Energy-Loss Profiles of Transmitted Electrons Incident on Dielectric Spheroids," Uliramicroscopy 35, $1-10(199.1)$ 
Jacobson, K.B., Arlinghaus, H.F., Schmitt, H.W., Sachleben, R.A., Brown, G.M., Thonnard, N., Sloop, F.V., Foote, R.S., Larimer, F.W., Woychik, R.P., England, M.W., Burchett, K.L., and Jacobson, D.A., "An Approach to the Use of Stable Isotopes for DNA Sequencing," Genomics 9, 51-59 (1991)

Janke, C.J., Muhs, J.D., Wachter, E.A., Ziegler, R.E., Powell, G.L., Smyrl, N.R., and Philpot, H.E., Composite Heat Damage Spectroscopic Analysis - Part 1. Mechanical Testing of IM6/3501-6 Laminates, Part 2. Laser-Pumped Fluorescence Spectroscopic Studies on IM6/3501-6 Laminates, Part 3. Diffuse Re, ORNL/ATD-42

Jia, J.J., Callcott, T.A., O'Brien, W.L., Dong, Q.Y., Rubensson, J.-E., Mueller, D.R., Ederer, D.L., and Rowe, J.E., "Local Partial Densities of States in Ni and Co Silicides Studied by Soft-X-Ray-Emission Spectroscopy," Phys. Rev. B 43, 4853$70(1991)$

Johnson, C.A., Ellis, J.R., Gibson, K.N., Norman, V.S., Rader, K.J., and Rhew, D.D., Biomedical and Environmental Sciences Program Publications 1989, ORNL6619

Jones, T.D. and Walsh, P.J., "Cancer Models for B(a)P, Benzene, Benzidine, and Chromium," Am. Soc. Civ. Eng. J. Energy Eng. 116, 211-30 (1990)

Jones, T.D., "Risk Analysis: Fundamental Concepts, Regulatory Toxicology, and Relative Comparisons from Radiation Biology," Proc. 23rd Midyear Top. Health Phys. Soc. Symp. on Risk Analysis, Atlantic City, NJ, Feb. 5-8, 1990, 1990, pp. 11-27

Jones, T.D., Owen, B.A., and Trabalka, J.R., "Protection of Human Health from Mixtures of Radionuclides and Chemicals in Drinking Water," Arch. Environ. Contam. Toxicol. 20, 143-50 (1991)

Jones, T.D. and Morris, M.D., Progress Report on IACRO DNA 90-818 - Protracted Dose Biophysics, March 31, 1990, ORNL/M-1159

Jones, T.D., Owen, B.A., Trabalka, J.R., Barnthouse, L.W., Easterly, C.E., and Walsh, P.J., "Chemical Pollutants: A Caricaturized Logos for Future Planning," Environ. Auditor 2, 71-88 (1991)

Jones, T.D. and Easterly, C.E., "On the Rodent Bioassays Currently Being Conducted on 44 Chemicals: A RASH Analysis to Predict Test Results from the National Toxicology Program," Mutagenesis 6, 507-14 (1991)

Kairemo, K.J.A., Kestila, M.S., Korhola, O.A., Hiltunen, J.V., Svahn, R.I., Knapp, F.F., Jr., and Brihaye, C., "Determination of Kidney Perfusion Using Ultra-Short Lived IR-191m as a Tracer," Eur. J. Nucl. Med. 16, 42 (1990)

Kamada, M. and Arakawa, E.T., "Sputtering of Excited-State Potassium Atoms from Electron-Bombarded KBr Crystals," J. Vac. Sci. Technol. A 8, 3152-56 (1990)

Kamada, M., Yamamoto, H., and Arakawa, E.T., "Atomic and Molecular Spectra from Electron-Excited Alkali Halides," Rev. Solid State Sci. 4, 733-40 (1990) 
Kavlock, R.J., Greene, J.A., Kimmel, G.L., Morrissey, R.E., Owens, E.T., Rogers, J.M., Sadler, T.W., Stack, H.F., Waters, M.D., and Welsch, F., "Activity Profiles of Developmental Toxicity: Design Considerations and Pilot Implementation," Teratology 43, 159-85 (1991)

Kaye, S.V., "A Team of Two," (Newspaper Article) The Oak Ridger, Oak Ridge, TN, Apr.20, 1990

Kaye, S.V., Description of Organizational Components, ORNL/M-1237

Kaye, S.V., Health and Safety Research Division Progress Report for the Period October 1, 1988 - March 31, 1990, ORNL-6621

Kearl, P.M., Zinkl, R.J., Dexter, J.J., and Cronk, T., "Air Permeability Measurements of the Unsaturated Bandelier Tuff Near Los Alamos, New Mexico," J. Hydrol. 117, $225-40(1990)$

Kerr, G.D., Dyer, F.F., Emery, J.F., Pace, J.V., III, Brodzinski, R.L., and Marcum, J., Activation of Cobalt by Neutrons from the Hiroshima Bomb, ORNL-6590

Kerr, G.D. and Eckerman, K.F., Source Inventory Limits, ORNL/TM-11497

Kerr, G.D. and Eckerman, K.F., "Source Inventory Limits," Health Phys. 59, 931-34 (1990)

Kerr, G.D. and Eckerman, K.F., "Applications of Nuclear Data in Human Radiation Dosimetry," Trans. Am. Nucl. Soc. 63, 170-71 (1991)

Khare, B.N., Thompson, W.R., Sagan, C., Arakawa, E.T., Meisse, C., and Gillmour, I., "Optical Constants of Kerogen from 0.15 to $40 \mathrm{Mu}-\mathrm{M}$ : Comparison with Meteoritic Organics," Proc. 1st Int. Conf. on Laboratory Research for Planetary Atmospheres, Bowie, MD, Oct. 25-27, 1989, NASA Conf. Publ. 3077, 1990, pp. 340-56

Khare, B.N., Thompson, W.R., Sagan, C., Arakawa, E.T., Bruel, C., Judish, J.P., Khanna, R.K., and Pollack, J.B., "Optical Constants of Solid Methane," Proc. Ist Int. Conf. on Laboratory Research for Planetary Atrnospheres, Bowie, MD, Oct. 2527, 1989, pp. 327-39

Klots, C.E., Hamm, R.N., Wright, H.A., and Turner, J.E., "Non-Homogeneous Kinetics in Irradiated Matter: An Appraisal of Computational Strategies," Radiat. Prot. Dosim. 31, 29-31 (1990)

Klots, C.E., "Thermal Kinetics in Small Systems II: Generalized Arrhenius Plots with Applications to the Dissociation of Benzene and Substituted-Benzene Cations," J. Chern. Phys. 93, 2513-20 (1990)

Klots, C.E., "Evaporative Corrections to High-Pressure Ionic Clustering Data," Int. J. Mass Spectrom. Ion Proc. 100, 457-63 (1990) 
Klots, C.E., "Thermal Kinetics in Small Systems. III. Isotope Effects," J. Chem. Phys. 93, $6585-88(1990)$

Klots, C.E., "Systematics of Evaporation," Z. Phys. D 20, 105-9 (1991)

Klots, C.E., "Kinetic Methods for Quantifying Magic," Book of Abstracts, East Coast Symp. on Chemistry and Physics of Clusters and Cluster Ions, Baltimore, Jan. 1416, 1991 (1991), p. 15

Klots, C.E., "Quasiequilibrium Rate Constants for Thermionic Emission from Small Particles," Chem. Phys. Lett. 186, 73-76 (1991)

Knapp, F.F., Jr., Reske, S.N., Ambrose, K.R., Kohlen, S., Kolkmeier, J., Goodman, M.M., and Cunningham, E.B., "Formation of Polar Products from Radioiodinated 15-(p-Iodophenyl)-3-(R,S)-Methylpentadecanoic Acid (BMIPP) by Isolated Langendorff Rat Hearts," NucCompact, Compact News Nucl. Med. 21, 133-39 (1990)

Knapp, F.F., Jr., Ambrose, K.R., Dudczak, R., Reske, S.N., and Kropp, J., "Catabolism of 15-(p-Iodophenyl)-3-R,S-methylpentadecanoic Acid (BMIPP) by Isolated Rat Hearts - Letter to the Editor," Eur. J. Nucl. Med. 16, 367-68 (1990)

Knapp, F.F., Jr., Ambrose, K.R., Callahan, A.P., Allred, J.F., Hasan, A., Lambert, C.R., McPherson, D.W., Mirzadeh, S., Srivastava, P.C., Lambert, S.J., and Rice, D.E., Nuclear Medicine Program Progress Report for Quarter Ending December 31, 1989, ORNL/TM-11427

Knapp, F.F., Jr., Ambrose, K.R., Callahan, A.P., Allred, J.F., Hasan, A., Lambert, C.R., McPherson, D.W., Mirzadeh, S., Srivastava, P.C., Lambert, S.J., and Rice, D.E., Nuclear Medicine Program Progress Report for Quarter Ending June 30, 1990, ORNL/TM-11570

Knapp, F.F., Jr., Ambrose, K.R., Callahan, A.P., Allred, J.F., Hasan, A., Lambert, C.R., McPherson, D.W., Mirzadeh, S., Srivastava, P.C., Lambert, S.J., and Rice, D.E., Nuclear Medicine Program Progress Report for Quarter Ending March 31, 1990, ORNL/TM-11550

Knapp, F.F., Jr., Ambrose, K.R., Callahan, A.P., Allred, J.F., Hasan, A., Lambert, C.R., McPherson, D.W., Mirzadeh, S., Srivastava, P.C., Lambert, S.J., and Rice, D.E., Nuclear Medicine Program Progress Report for Quarter Ending September 30, 1990, ORNL/TM-11721

Knapp, F.F., Jr., Ambrose, K.R., Callahan, A.P., Allred, J.F., Hasan, A., Lambert, C.R., McPherson, D.W., Mirzadeh, S., Srivastava, P.C., Lambert, S.J., and Rice, D.E., Nuclear Medicine Program Progress Report for Quarter Ending December 21,1990, ORNL/TM-11755

Knapp, F.F., Jr., Lisic, E.C., Mirzadeh, S., Callahan, A.P., and Rice, D.E, "A New Clinical Prototype W-188/Re-188 Generator to Provide High Levels of Carrier-Free Rhenium-188 for Radioimmunotherapy (RAIT)," Eur. J. Nucl. Med. 18, 538 (1991) 
Knapp, F.F., Jr., Ambrose, K.R., Callahan, A.P., McPherson, D.W., Mirzadeh, S., Srivastava, P.C., Allred, J.F., Hasan, A., Lambert, C.R., Lambert, S.J., and Rice, D.E., Nuclear Medicine Program Progress Report for Quarter Ending March 31, 1991, ORNL/TM-11830

Knapp, F.F., Jr., Ambrose, K.R., Callahan, A.P., McPherson, D.W., Mirzadeh, S., Srivastava, P.C., Hasan, A., Lambert, C.R., Lambert, S.J., and Rice, D.E., Nuclear Medicine Program Progress Report for Quarter Ending June 30, 1991, ORNL/TM11881

Knott, R.R. and Little, C.A., Quality Assurance Program Plan for the Radiological Survey Activities Program - Uranium Mill Tailings Remedial Action Project, ORNL/TM-9684/R2

Knox, N.P., Webb, J.R., Ferguson, S.D., Goins, L.F., and Owen, P.T., Nuclear Facility Decommissioning and Site Remedial Actions; A Selected Bibliography, Vol. 11 , ORNL/EIS-154/V11

Kocher, D.C., "Development of Closure Criteria for Inactive Radioactive Waste Disposal Sites at Oak Ridge National Laboratory," Proc. 28th Hanford Symp. on Health and the Environment, Richland, WA, Oct. 16-19, 1989, Pacific Northwest Lab., 1990, pp. 117-23

Kocher, D.C., "Classification and Disposal of Radioactive Wastes - History and Legal and Regulatory Requirements," Radiat. Prot. Manage. 7, 58-78 (1990)

Kocher, D.C., "A Validation Test of a Model for Long-Term Retention of ${ }^{129} \mathrm{I}$ in Surface Soils," Health Phys. 60, 523-31 (1991)

Kocher, D.C., Preliminary Assessment of Radiation Doses to the Public from $1{ }^{137} \mathrm{Cs}$ Contamination Along Railroad Tracks in Oak Ridge, ORNL/ER-28

Kocher, D.C., Applicable or Relevant and Appropriate Regulatory Requirements for Remediation of Radioactively Contaminated Waste Disposal Sites, ORNL/ER-31

Kocher, D.C., "Dose Assessment for a ${ }^{137}$ Cs Contamination Incident," Trans. Am. Nucl. Soc. 64, 120-21 (1991)

Komaki, K., Yamazaki, Y., Iwata, Y., Ritchie, R.H., Crawford, O.H., and Ashley, J.C., "MUSE Experiments and Monte Carlo Simulation," Proc. U.S.-Japan Workshop on Atomic Collisions in Solids, Honolulu, Feb. 2-9, 1990, CONF900276,1990 , p. 11

Kropp, J., Knapp, F.F., Jr., Ambrose, K.R., Visser, F., Biersack, H.-J., and Blystone, S.L., "Release of an Unexpected Myocardial Metabolite of Radioiodinated 15-(p-Iodophenyl)-3-R,S-Methylpentadecanoic Acid (BMIPP) from Isolated Rat Hearts and Canine Hearts In Vivo," J. Nucl. Med. 31, 896 (1990) 
Kropp, J., Knapp, F.F., Jr., Nissen, H.P., Assmann, T., Ambrose, K.R., and Biersack, H.J., "Metabolites of IPPA, BMIPP, and DMIPP Fatty Acids in Rat Hearts. A Quantitative HPLC-Study," Proc, European Assoc. of Nuclear Medicine, Amsterdam, May 20-24, 1990 (1991), pp. 109-11

Kropp, J., Joch, M., Likungu, J., Kirchhoff, P.G., Knapp, F.F., Jr,, Reichmann, K., Reske, S.N., and Blersack, H,-J., "Evaluation of the Preservation of Myocardial Viability by SPECT Imaging with (I-123)IPPA Before and After Coronary Bypass Surgery," Eur. J. Nucl. Med. 18, 467-74 (1991)

Kropp, J., Kohler, U, Nitsch, J., Likungu, J., Biersack, H.J., and Knapp, F.F., Jr., Imaging of Myocardial Metabolism Before and After Revascularisation,"

NucCompact, Compact News Nucl. Med. 21, 219-22 (1990)

Kropp, J., Knapp, F.F., Jr., Ambrose, K.R., Assmann, T., Urmetz, S., Nissen, H.P., and Biersack; H.J., "Metabolites of IPPA, BMIPP, and DMIPP Fatty Acids in Rat Hearts," Eur. J. Nucl. Med. 16, 408 (1990)

Kuklinski, D.M., King, K.H., Addison, J.T., and Travis, C.C., Conventionally Altered Organisms: Database on Survival, Dispersal, Fate, and Pathogencity, ORNL-6614

Lambert, S.J., Kablaka, G.W., Knapp, F.F., Jr.. and Srivastava, P.C., "The Unexpected Anti-Markovnikov Addition of Iodine Monochloride to Propargylamine Hydro-chlorides via Ionic Intermediates," J. Org. Chem. 56, 3707-11 (1991)

Landguth, D.C., Hatmaker, T.L., Burman, S.N., and Bohrman, D.E., Phase 2 Remedial Investigation Work Plan for the K-1070-C/D Classified Burial Ground at the Oak Ridge K-25 Site, Oak Ridge, Tennessee, Vol. 2: Quality Assurance Project Plan, ES/ER-9/V2\&D1

Landguth, D.C., Phase 2 Remedial Investigation Work Plan for the K-1070-C/D Classified Burial Ground at the Oak Ridge K-25 Site, Oak Ridge, Tennessee, Vol. 3: Field Sampling Plan, ES/ER-9/V3\&D1

Lee, I., Arakawa, E.T., Callcott, T.A., and Judish, J., "The Kinetic Energy Distribution of Au Atoms Desorbed by Laser-Induced Surface Plasmon Excitation," Bull. Am. Phys. Soc. 35, 537 (1990)

Lee, T.W., McPherson, D.W., Callahan, A.P., Rice, D.E., Ting, G., and Knapp, F.F., Jr., "A Simple Colorimetric Method for Determination of the Specific Activity of Spallation-Produced Copper-67 (Cu-67) Using the Bis-( ${ }^{4}$ methyl)Thiosemicarbazone (TSC) Derivative of Phenylglyoxal," J. Labelled Compd. Radiopharm. 30, 79-81 (1991)

Leggett, R.W. and Williams, L.R., "Suggested Reference Values for Regional Blood Volumes in Humans," Health Phys, 60, 139-54 (1991)

Lisic, E., Mirzadeh, S., Callahan, A.P., and Knapp, F.F., Jr, "A New Tandem Generator/Ion Exchange System Providing Carrier-Free Rhenium-188-Perrhenic Acid for Antibody Labeling," J. Nucl. Med. 32, 945 (1991) 
Liu, J.C. and Sims, C.S., "Characterization of the Harshaw Albedo TLD and the Bubble Detectors (BD-100R and BDS-1500)," Radiat. Prot. Dosim. 32, 21-32 (1990)

Liu, J.C. and Sims, C.S., "Performance Evaluation of a New Combination Personnel Neutron Dosimeter," Radiat. Prot. Dosim. 32, 33-43 (1990)

Liu, J.C., Sims, C.S., West, L., and Welty, T., "Angular Response Performance Study of a New Harshaw Neutron Albedo TLD," Radiat. Prot. Dosim. 30, 161-68 (1990)

Liu, J.C., Hajnal, F., Sims, C.S., and Kuiper, J., "Neutron Spectra Measurements at ORNL," Radiat. Prot. Dosim. 30, 169-78 (1990)

Liu, J.C., Sims, C.S., Casson, W.H., Murakami, H., and Francis, C., "Neutron Scattering in ORNL's Calibration Facility," Radiat. Prot. Dosim. 35, 13-21 (1991)

Lowndes, D.H., Norton, D.P., Budai, J.D., Christen, D.K., Klabunde, C.E., Warmack, R.J., and Pennycook, S.J., "Growth and Transport Properties of Y-BaCu-O/Pr-Ba-Cu-O Superlattices," Proc. Soc. Photo-Opt. Instrum. Eng. Conf. on. Progress in High-Temperature Superconducting Transistors and Other Devices, Santa Clara, Oct. 4-5, 1990, SPIE, 1990, v. 1394, pp. 150-60

Lu, P.-L., Young, R.A., Francis, M.W., Ross, R.H., and Fisher, J.W., "Toxicology Guide for Installation Restoration Program Application," The Toxicologist 10, 89 (1990)

Lu, P.-Y., Francis, M.W., Reisman, D.J., and DeRosa, C., "Toxicological Information for Hazard Evaluation: The Chemical Unit Risk Estimate Database," Proc. Symp. on Health Risk Assessment on Environmental, Occupational and LIfe Style Hazards, Oak Ridge, TN, Dec. 20-22, 1988 (1991, pp. 143-56

Lu, P.-Y., Symposium on Access and Use of Information Resources in Assessing Health Risks from Chemical Exposure, June 27-29, 1990, ORNL/M-1207

Lu, P.Y., Young, R.A., Ross, R.H., and Jepson, G.W., "Regulatory Status and Toxicologic Overview of Metals and Metal Compounds of Interest to the U.S. Air Force Installation Restoration Program," The Toxicologist 11(1), 195 (1991)

Mansfield, B.K. and Wyrick, J.M., Human Genome Quarterly, Vol. 1, No. 3, Winter 1990, ORNL/M-1089

Mansfield, B.K. and Wyrick, J.M., Human Genome News, Vol. 2, No. 1, May 1990, ORNL/M-1130

Mansfield, B.K. and Wyrick, J.M., Human Genome News, Vol. 2, No. 3, September 1990, ORNL/M-1253

Mansfield, B.K. and Wyrick, J.M., Human Genome News, Vol. 2, No. 2, July 1990, ORNL/M-1195

Mansfield, B.K. and Wyrick, J.M., Human Genome News, Vol. 2, No. 4, November 1990, ORNL/M-1315 
Mansfield, B.K. and Wyrick, J.M., Human Genome News, Vol, 2, No. 6, March 1991, ORNL/M-1377

Mansfield, B.K. and Wyrick, J.M., Human Genome News, Vol. 3, No. 1, May 1991, ORNL/M-1440

Mansfield, B.K. and Wyrick, J.M., Human Genome News, Vol. 2, No. 5, January 1991, ORNL/M-1344

Mansfield, B.K. and Wyrick, J.M., Human Genome News, Vol. 3, No. 2, July 1991, ORNL/M-1527

Mansfield, B.K. and Wyrick J.M., Human Genome News, Vol. 3, No. 4, November 1991, ORNL/M-1789

Manson, J.R. and Ritchie, R.H., "Multiphonon Energy Exchange in the Collision of an Atom with a Surface," Proc. 12th Werner Brandt Int. Conf. on Penetration of Charged Particles in Matter, San Sebastian, Spain, Sept. 4-7, 1989, CONF-8909210, 1990, pp. 313-28

Manson, J.R. and Ritchie, R.H., "Multiphonon Energy Exchange in Atom-Surface Collisions," Proc. U.S.-Japan Workshop on Atomic Collisions in Solids, Honolulu, Feb. 2 -9, 1990, CONF-900276, 1990, p. 7

Mantovani, J.G., Warmack, R.J., Annis, B.K., MacDiarmid, A.G., and Scherr, E., "Investigation of Surface Morphology of Emeraldine Hydrochloride by Scanning Tunneling Microscopy," J. Appl. Polym. Sci. 40, 1693-702 (1990)

Mantovani, J.G., Allison, D.P., Warmack, R.J., Ferrell, T.L., Ford, J., Manos, R.E., Thompson, J.R., Reddick, B., and Jacobson, K.B., "Scanning Tunneling Microscopy of Tobacco Mosaic Virus on Evaporated and Sputter Coated Palladium/Gold Substrates," J. Microsc. 158, 109-16 (1990)

Mantovani, J.G., Warmack, R.J., Annis, B.K., MacDiarmid, A.G., and Scherr, E., "Investigation of Surface Morphology of Emeraldine Hydrochloride by Scanning Tunneling Microscopy," J. Appl. Polym. Sci. 40, 1693-1702 (1990)

Martin, F.M., Daugherty, M.W., Talmage, S.S., Smith, B.G., and DeRosa, C., "Toxicology and Quantitative Risk Assessment of Environmental Exposure to 2Methyl-4-Chlorophenoxyacetic Acid (MCPA)," The Toxicologist 10, 1399 (1990)

Matthews, T.G., Wilson, D.L., Thompson, C.V., Monar, K.P., and Dudney, C.S., "Impact of Heating and Air Conditioning System Operation and Leakage on Ventilation and Intercompartment Transport: Studies in Unoccupied and Occupied Tennessee Valley Homes," J. Air Pollut. Control Assoc. 40, 194-98 (1990)

Mavournin, K.H., Blakey, D.H., Cimino, M.C., Salamone, M.F., and Heddle, J.A., "The In Vivo Micronucleus Assay in Mammalian Bone Marrow and Peripheral Blood. A Report of the U.S. Environmental Protection Agency Gene-Tox Program," Mutat. Res. 239, 29-80 (1990) 
McPherson, D.W., Umbricht, G., and Knapp, F.F., Jr., "Radiolabeling of Proteins with Radiosiotopes of Copper Using p-Carboxyalkylphenylglyoxal bis- ${ }^{4} \mathrm{~N}$ methylthiosemicarbazone) (TSC) Bifunctional Chelate," J. Labelled Compd. Radiopharm. 28, 877-99 (1990)

McPherson, D.W., Lee, T.W., and Knapp, F.F., Jr., "A Simple Colorimetric Method for Determination of the Specific Activity of Spallation-Produced Copper-67 Using Phenylglyoxal (PG) Bis-( ${ }^{4} \mathrm{~N}$-methyl) Thiosemicarbazone (TSC) Derivatives," Appl. Radiat. Isot. 41, 689-92 (1990)

McPherson, D.W., Callahan, A.P., Ambrose, K.R., and Knapp, F.F., Jr., "Stability of Copper(II)-Bis-(N ${ }^{4}$-Substituted)thiosemicarbazone (TSC) Protein Complexes," $J$. Nucl. Med. 32, 944 (1991)

McPherson, D.W., Callahan, A.P., Lambert, C.R., and Knapp, F.F., Jr., "Preparation and Biodistrubition of Iodine-125 Labeled Quinuclidinyl Esters as Potential Ligands for SPECT Studies of Muscarinic Receptors," J. Nucl. Med. 32, 1093 (1991)

Miller, C.W., Cottrell, W.D., Loar, J.M., and Witherspoon, J.P., "Examination of the Impact of Radioactive Liquid Effluent Releases from the Rancho Seco Nuclear Power Plant," Health Phys. 58, 263-74 (1990)

Miller, D.R., Allison, D.P., Rorvik, M.C., and Slaga, T.J., "Inhibited Morphological Terminal Differentiation and Enhanced Proliferation of Cultured Mouse Epidermal Cells at Different Concentrations of Dimethyl Sulphoxide," Cell Proliferation 24, $191-210(1991)$

Miller, J.C. and Smith, D.B., "Resonance Ionization Spectroscopy of Molecular Clusters Using Picosecond Lasers," Resonance Ionization Spectroscopy 1990, Proc. 5th Int. Symp. on Resonance Ionization Spectroscopy and Its Applications, Varese, Italy, Sept. 16-21, 1990, Irıst. of Physics, Bristol, 1991, pp. 163-68

Miller, J.C. and Barton, D., "Picosecond Multiphoton Ionization of Atomic and Molecular Clusters," Proc. 5th Int. Conf. on Multiphoton Processes, ICOMP V, Paris, Sept.24-28, 1990, CEA Press, France, 1991, pp. 283-92

Miller, J.C., Workshop on Advanced Laser Technology for Chemical Measurements, Oak Ridge, TN, November 12-14, 1990, Oak Ridge National Laboratory, 1990, CONF-9011110--Absts

Miller, P.D., Skiles, J.L., Michel, K.L., and White, R.K., Qualitative Evaluation of K1417 Drum Storage Facility, ES/ER/TM-9

Mirzadeh, S., Brechbiel, M.W., and Gansow, O.A., "Radiometal Labeling of Immunoproteins: A Study of the Covalent Attachment of SCN-Bzl-DTPA Ligands to Immunoglobulin," Bioconjugate Chem. 1, 59-65 (1990)

Mirzadeh, S., Callahan, A.P., and Knapp, F.F., Jr., "Iridium-194 - A New Candidate for Radioimmunotherapy (RAIT) from an Osmium-194/Iridium-194 Generator System," J. Nucl. Med. 32, 1089 (1991) 
Mo, G., Sung, C.C., and Ritchie, R.H., "Bound States of Electrons in the Vicinity of a Dielectric Sphere," Chem. Phys, Lett, 176, 433-38 (1991)

Mossman, K.L., Kerr, G.D., Meinhold, C.B., Sikov, M.R., Smathers, J.B., and Ullrich, R.L., A Technical Review and Assessment of the BEIR V Report, ORNL/M1164

Moyer, P.J., Jahncke, C.L., Paesler, M.A., Reddick, R.C., and Warmack, R.J., "Spectroscopy in the Evanescent Field with an Analytical Photon Scanning Tunneling Microscope," Phys, Lett. A145, 343-47 (1990)

Munro, N.B., Watson, A.P., Ambrose, K.R., and Griffin, G.D., "Treating Exposure to Chemical Warfare Agents: Implications for Health Care Providers and Community Emergency Planning," Environ. Health Perspect. 89, 205-15 (1990)

Munro, N.B., Shugart, L.R., Watson, A.P., and Halbrook, R.S., "Cholinesterase Activity Levels in Domestic Animals as a Potential Blomonitor for Nerve Agent and Other Organophosphate Exposure," J. Am. Vet. Med. Assoc. 199, 102-15 (1991)

Narayanan, V.A., Bello, J.M., Stokes, D.L., and Vo-Dinh, T., "Surface-Enhanced Raman Anlysis of Vitamin B Complex: Quantitative Detection of p-Aminobenzoic Acid," J. Raman Spectrosc. 22, 327-31 (1991)

Norman, D., Live, D., Sastry, M., Lipman, R., Hingerty, B.E., Tomasz, M., Broyde, S., and Patel, D.J., "NMR and Computational Characterization of Mitomycin CrossLinked to Adjacent Deoxyguanosines in the Minor Groove of the d(T-A-C-G-TA).d(T-A-C-G-T-A) Duplex," Biochemistry 29, $2861-75$ (1990)

Norton, D.P., Lowndes, D.H., Zheng, X.-Y., Zhu, S., and Warmack, R.J., "Scanning Tunneling Microscopy of Pulsed-Laser-Deposited $\mathrm{YBa}_{2} \mathrm{Cu}_{3} \mathrm{O}_{78}$ Epitaxial Thin Films: Surface Microstructure and Growth Mechanism," Phys. Rev. B 44, 9760.63 (1991)

Nyquist, J.E., Wilson, D.L., Norman, L.A., and Gammage, R.B., "Decreased Sensitivity of Photoionization Detector Total Organic Vapor Detectors in the Presence of Methane," Am. Ind. Hyg. Assoc. J. 51, 326-30 (1990)

Nyquist, J.E. and Blair, M.S., "An Automatic Locating and Data Logging System for Radiological Walkover Surveys," Proc. 31st Annu. Meet. of Inst. for Nuclear Materials Management, Los Angeles, July 15-18, 1990 (1990), pp. 959-63

Nyquist, J.E. and Blair, M.S., "An Automated Locating and Data Logging System for Geophysical Surveys," Proc. 4th Natl. Outdoor Action Conf., Las Vegas, May 14. 17, 1990, Natl. Well Water Assoc., Dublin, OH, 1990, pp. 99-113

Nyquist, J.E. and Blair, M.S., "A Geophysical Tracking and Data Logging System: Description and Case History," Geophysics 56, 1114-21 (1991)

Opresko, D.M. and Genin, A., "A New Species of Antipatharian (Cnidaria: Anthozoa) from Seamounts in the Eastern North Pacific," Bull. Mar. Sci. 46, 301-10 (1990) 
Opresko, D.M., Lu, P.-Y., and Greenberg, M., "Health Risk Assessment of Inhalation Exposure to "Trichloroethylene (TCE)," The Toxicologist 10, 350 (1990)

Opresko, D.M., Evaluation of the Chronic Systemic Toxicity and Potential Carcinogenicity of para-Nitrophenol (Draft), ORNL/M-1515

Owen, B.A. and Jones, T.D., "Hazard Evaluation for Complex Mixtures: Relative Comparisons to Improve Regulatory Consistency," Regul. Toxicol. Pharmacol. 11, $132-48(1990)$

Owen, B.A., "Literature-Derived Absorption Cuefficients for 39 Chemicals via Oral and Inhalation Routes of Exposure," Regul, Toxicol. Pharmacol. 11, 237-52 (199())

Owen, B.A., Dudney, C.S., Tan, E.L., and Easterly, C.E., "Formaldehyde in Drinking Water: Comparative Hazard Evaluation and an Approach to Regulation," Regul. Toxicol. Pharmacol. 11, 220).36 (1990)

Owen, B.A., Dudney, C.S., Tan, E., and Easterly, C.E., Comparative Hazard Evaluation, and Approach to Regulation: Formaldehyde in Drinking Water, ORNL6592

Owen, P.T., Goins, L.F., and Knox, N.P., "Environmental Restoration and Waste Management Data Bases," Abstracts of Symp. on Access and Use of Information Resources in Assessing Health Risk from Chemical Exposure, Oak Ridge, TN, June 28, 1990, EPA, 1990

Paesler, M.A., Moyer, P.J., Jahncke, C.J., Johnson, C.E., Reddick, R.C., Warmack, R.J., and Ferrell, T.L., "Analytical Photon Scanning Tunneling Microscopy," Phys. Rev. B 42, 6750-53 (1990)

Panter, M.S., Burman, S.N., Landguth, D.C., and Uziel, M.S., Work Plan, Health and Safety Plan, and Quality Assurance Project Plan for Hazardous Waste Removal at the CTF K-1654B Underground Collection Tank, ORNL-6697

Paretzke, H.G., Turner, J.E., Hamm, R.N., Ritchie, R.H., and Wright, H.A., "Spatial Distributions of Inelastic Events Produced by Electrons in Gaseous and Liquid Water," Radiat, Res. 127, 121-29 (1991)

Payne, M.G. and Garrett, W.R., "Large Pressure-Dependent Cooperative Shifts in Multicolor Odd-Photon Resonant Atomic Excitation," Phys. Rev. A 42, 1434-41 (199())

Payne, M.G., Garrett, W.R., Hart, R.C., and Datskou, I., "Relation Between Collective Lamb Shifts and the High.Pressure Odd-Photon Cancellation Effect," Phys, Rev, A 42, 2756-65 (1990)

Payne, M.G., Garrett, W.R., Hart, R.C., Datskou, I., and Wray, J., "Large Collective Lamb Shifts in High Pressure Noble Gases," Proc. 5th Int. Symp. on Resonance Ionization Spectroscopy and Its Applications, RIS '90, Varese, Italy, Sept. 16-21, 1990, Inst. of Physics Conf. Ser. No. 114, Section 5, 1990, pp. 209-13 
Payne, M.G., Allman, S.L., and Parks, J.E., "Effect of Hyperfine Structure on Ionization Efficiencies in Stepwise lonization Using Broad Bandwidth Lasers," Spectrochim. Acta B 46, 1439-57 (1991)

Pegg, D.J., Thompson, J.S., Dellwo, J., Compton, R.N., and Alton, G.D., "Partlal Cross Sections for the Photodetachment of Metastable He"," Phys. Rev. Lett. 64, 278-81 (1990)

Piccard, R.D. and Vo-Dinh, T., "A Multi-Optical-Fiber Array with Charge-Coupled Device Image Detection for Parallel Processing of Light Signals and Spectra," Rev. Sci. Instrum. 62, 584-94 (1991)

Pinnaduwage, L.A. and Christophorou, L.G., "Enhanced Electron Attachment to Molecular Superexcited States," Bull. Am. Phys. Soc. 35, 939 (1990)

Pinnaduwage, L.A. and Christophorou, L.G., "Enhanced Electron Attachment to Superexcited States of Saturated Tertiary Amines," J. Chem. Phys. 95, 274-87 (1991)

Pitarke, J., Echenique, P.M., and Ritchie, R.H., "Density Fluctuation Detection," Proc. U.S.IJapan Workshop on Atomic Collisions in Solids; Honolulu, Feb. 2-9, 1990, CONF-900276, 1990, p. 13

Pitarke, J.M. and Ritchie, R.H., "Radiative Electron Capture by Channeled Ions," Proc. 12th Werner Brandt Int. Conf. on Penetration of Charged Particles in Matter, San Sebastian, Spain, Sept. 4-7, 1989, CONF-8909210, 1990, pp. 273-88

Pitarke, J.M., Ritchie, R.H., and Echenique, P.M., "Radiative Electron Capture by Channeled lons," Phys, Rev, B 43, 62-70 (1991)

Purcell, K.J., Cason, G.H., Gargas, M.L., Andersen, M.E., and Travis, C.C., "In Vivo Metabolic Interactions of Benzene and Toluene," Toxicol. Lett. 52, 141-52 (1990)

Reddick, R.C., Warmack, R.J., Chilcott, D.W., Sharp, S.L., and Ferrell, T.L., "Photon Scanning Tunneling Microscopy," Rev. Sci. Instrum. 61, 3669-77 (1990)

Reed, R.M., Easterly, C.E., Evans, D.M., Kroodsma, R.L., Llebsch, E.J., McLean, R.B., and Voorhees, L.D., Final Starlab Program Environmental Assessment, ORNL/M-1254

Reisman, D.J., DeRosa, C., Francis, M.W., and Lu, P.-Y., "The Cure: A Database of Health Risk Assessment Information for Future Research," The Toxicologist 10, 73 (1990)

Ritchie, R.H., Howie, A., Echenique, P.M., Basbas, G.J., Ferrell, T.L., and Ashley, J.C., "Plasmons in Scanning Transmission Electron Microscopy (STEM) Electron Spectra," Scanning Microsc. 4, 45-56 (1990)

Ritchie, R.H., "Introduction and Ovcrview," Proc. 12th Werner Brandt Int. Conf. on Penetration of Charged Particles in Matter, San Sebastian, Sept. 4-7, 1989, CONF.89090210, 1990, pp. vii-viii 
Ritchie, R.H., Gras-Martl, A., and Ashley, J.C., "The Theory of Track Formation in Insulators Due to Densely Ionizing Particles," Proc, 12th Werner Brandt Int. Conf. on Penetration of Charged Particles in Matter, San Sebastian, Spain, Sept. 4-7, 1989, CONF-8909210, 1990), pp. 595-613

Ritchie, R.H., "Plasmon Decay," Proc. U.S.IJapan Workshop on Atomic Collisions in Solids, Honolulu, Feb. 2-9, 1990, CONF-900276, 1990, p. 17

Ritchie, R.H., Proceedings of the 12th Werner Brandt International Conference on the Penetration of Chargetl Particles in Matter, San Sebastian, Spain, September 4-7, 1989, Oak Ridge National Laboratory, 1990, CONF-890210

Ritchie, R.H., Echenique, P.M., and Flores, F., "Image Potential Effects for Low- and High-Energy Electrons," Surfi. Sci. 251, 119 (1991)

Rodriguez, R.E., Witt, D.A., Cottrell, W.D., and Carrier, R.F., Results of Mobile Gamma Scanning Activities in St. Louis, Missouri, ORNL/RA.SA-90/7

Rogers, G.O., Watson, A.P., Sorensen, J.H., Sharp, R.D., and Carnes, S.A., Evaluating Protective Actions for Chemical Agent Emergencies, ORNL-6615

Ross, R.H. and Hartley, W.R., "Comparison of Water Quality Criteria and Health Advisories for 2,4,6-Trinitrotoluene," Regul. Toxicol. Pharmacol. 11, 114-17 (1990)

Ross, R.H., Lu, P..Y., and Hartley, W.R., "Comparison of a Water Quality Criterion and the Lifetime Health Advisory for 2,4,6-Trinitrotoluene," The Toxicologist 10, $138(1990)$

Ross, R.H. and O'Bryan, T.R., "Chemical Scoring System for Hazard and Exposure Identification," The Toxicologist 11, 916 (1991)

Ryon, M.G. and Ross, R.H., "Water Quality Criteria for 2,4,6-Trinitrotoluene (TNT)," Regul. Toxicol. Pharmacol. 11, 104-13 (1990)

Sachleben, R.A., Brown, G.M., Sloop, F.V., Arlinghaus, H.F., England, M.W., Foote, R.S., Larimer, F.W., Woychik, R.P., Thonnard, N., and Jacobson, K.B., "Resonance Ionization Spectroscopy for Multiplex Sequencing of Tin-Labeled DNA," GATA 8, $167-70$ (1991)

Saha, H.P. and Compton, R.N., "Theoretical Studies of the Photophysics of $\mathrm{He}(1 \mathrm{~s} 2 \mathrm{~s} 2 \mathrm{p})^{4} \mathrm{P}^{0}, "$ Phys. Rev. Lett. 64, 1510-13 (1990)

Salk, M.S. and Heckman, C.G., Environmental Guidance Program Reference Book Safe. Drinking Water Act (Revision 5), ORNL/M-1127

Schauer, S.N., Williams, P., and Compton, R.N., "Production of Small Doubly Charged Negative Carbon Cluster Ions by Sputtering," Phys. Rev. Lett. 65, 625-28 (1990) 
Schlick, T., Hingerty, B.E., Peskin, C.S., Overton, M.L., and Broyde, S., "Search Strategies, Minimization Algorithms, and Molecular Dynamics Simulations for Exploring Conformational Spaces of Nucleic Acids," Theoretical Biochemistry and Molecular Blophysics, Adenine Press, 1990, pp. 39.58

Shea, M.J. and Compton, R.N., "Ejection of Ag+ with $3.5 \mathrm{eV}$ Kinetic Energy by Laser R.adiation on a Roughened Silver Surface," Bull. Am. Phys. Soc. 35, 433 (1990)

Shea, M.J., Hettich, R., and Compton, R.N., "Laser Ablation Studies of Palladium Electrolytically Loaded with Hydrogen and Deuterium," Bull. Am. Phys. Soc. 35, $371(1990)$

Shea, M.J., Compton, R.N., and Hettich, R.L., "Laser Ablation Studies of Palladium Electrolytically Loaded with Hydrogen and Deuterium," Phys. Rev. A 42, 3579-86 (1990)

Siegrist, R.L., Korte, N.E., Pickering, D.A., and Phelps, T.J., Bioremediation Demonstration of Kwajalein Island: Site Characterization and On-Site Biotreatability Studies, ORNL/TM-11894

Sims, C.S., Casson, W.H., Murakami, H., Liu, J.C., and Patterson, G.R., 1989 Neutron and Gamma Personnel Dosimetry Intercomparison Study Using RADCAL Sources', ORNL-6597

Sinclair, L.D., Dudney, C.S., Wilson, D.L., and Saultz, R.J., "Air Pressure Distribution and Radon Entry Processes in East Tennessee Schools," Proc. Int. Symp. on Radon and Radon Reduction Technology, Atlanta, Feb. 19-23, 1990 (1991), v. 1, pp. 9-61$-9-68$

Singh, S.B., Hingerty, B.E., Geacintov, N.E., Greenberg, J., and Broyde, S., "Molecular Dynamics Simulations of Oligomer Guanine $N^{2}-(+)$ and (-) Anti Benzo(a)pyrene Diol Epoxide Adducts with Solvent and Salt," Biophys. J. 57, 456a (1990)

Singh, S.B., Hingerty, B.E., Geacintov, N.E., Greenberg, J., and Broyde, S., "Molecular Dynamics Analyses of Duplex Dodecamer Modified by $(+)$ and (-) Anti BPDE and Modified Controls," Biophys, J. 59 (W-VCR3), 495a (1991)

Smith, D.B. and Miller, J.C., "Non-Resonant and Resonant Multiphoton Ionization of $(\mathrm{NO})_{\mathrm{n}}$ and $\mathrm{Ar}_{\mathrm{n}} \mathrm{NO}$ Clusters with Picosecond Laser Pulses, "J. Chem. Soc., Faraday Trans. 86, 2441-46 (1990)

Smith, D.B, and Miller, J.C., "Picosecond Multiphoton Ionization of Atomic and Molecular Clusters," Proc. Int. Conf. on Lasers, LASERS 89, New Orleans, Dec. 3-8, 1989, STS Press, Mclean, VA, 1990, pp. 737-42

Smuin, D.R., "Geology and Hydrology of the Shallow Alluvial Aquifer, West Sharrard Gulch, Colorado," Mt. Geol. 27, 107-18 (1990)

Smuin, D.R., Geology and Hydrology of the Shallow Alluvial Aquifer, West Sharrard Gulch, Colorado, ORNL/TM-11467 
Smuin, D.R. and Crutcher, J.W., Applicability of Environmental Laws to the Remedial Investigation and Cleanup of a Site at Naval Air Station, Fallon, Nevada, ORNL/TM11802

Som, P., Oster, Z.H., Goodman, M.M., and Knapp, F.F., Jr, "Microimaging Studies of Myocardial Substrate Utilization and Perfusion in Two Models of Non-Coronary Heart Disease," NucCompact, Compact News Nucl. Med. 21, 259-62 (1990)

Srivastava, P.C., Buchsbaum, D.J., Allred, J.F., Brubaker, P.G., Hanna, D.E., and Spicker, J.K., "A New Conjugating Agent for Radioiodination of Proteins: Low In Vivo Deiodination of a Radiolabeled Antibody in a Tumor Model," Biotechniques 8 , 536-45 (1990)

Srivastava, P.C. and Hasan, A., "The Synthesis of 2-Nitro-1-[(2 Hydroxyethoxy)methyl]imidazole (Azomycin Acyclonucleoside)," Nucleosides \& Nucleotides 9, 899. 905 (1990)

Srivastava, P.C., Lambert, C.R., Allred, J.F., Kennel, S.J., Hasan, A., and Buchsbaum, D.J., "I-125 Labeled Azomycin Acyclonucleoside: Design and Synthesis of an Attractive Misonidazole Analogue for Imaging Hypoxia," J. Nucl. Med. 31, 900 (1990)

Srivastava, P.C., Allred, J.F., Lambert, C.R., and Kennel, S.J., "No-Carrier-Added Preparation of a New Radioiodinated Maleimide as a Potentially Attractive Radioimmunoconjugator with Low In Vivo Deiodination," J. Nucl. Med. 31, 906 (1990)

Srivastava, P.C., Hasan, A., and Buchsbaum, D.J., "Iodoazomycin Acyclonucleoside: A Potential SPECT Imaging Agent with High Tumor Uptake," J. Labelled Compd. Radiopharm. XXX, 424-25 (1991)

Srivastava, P.C., Buchsbaum, D.J., and Hasan, A., "Design, Synthesis and Tumor, Specificity of Azomycin Ribo- and, Acyclonucleosides," Nucleosides \& Nucleotides 10, 235-38 (1991)

Srivastava, P.C., Tedjamulia, M.L., Owen, B.A., and Knapp, F.F., Jr., "Synthesis and Myocardial Specificity of p-(n-Alkyl)-(125I)Iodophenyl Fatty Acid Analogues," Indian J. Chem. 30B, 188-94 (1991)

Stafford, R.S., Lu, P.-Y., Francis, M.W., Reisman, D.J., and DeRosa, C., "A Personal Computer (PC) Version of the Cure Database of Health Risk Assessment Information," The Toxicologist 10(1), 89 (1990)

Stein, C., Habiger, K.W., Smith, B.R., Crawford, O.H., and Ritchie, R.H., "Bremsstrahlung Induced by $50 \mathrm{MeV} \mathrm{H}{ }^{0}$ Bombardment," Phys. Rev. B 41, 1715-21 (1990)

Sweeney, F.J., Baxter, V., Fairchild, P., Gammage, R.B., Trivelpiece, A., Krause, C., and Robinson, C., Oak Ridge National Laboratory Review, Vol. 23, No. 3, September 1990, ORNL/M-1283 
Talmage, S.S. and Walton, B.T., "Small Mammals as Monitors of Environmental Contaminants," Rev. Environ. Contam. Toxicol. 119, 47-145 (1991)

Talmage, S.S. and Walton, B.T., Comparative Evaluation of Several Small Mammal Species as Monitors of Heavy Metals, Radionuclides, and Selected Organic Compounds in the Environment, ORNL/TM-11605

Thein, M., Bogard, J.S., and Eckerman, K.F., "Estimation of ${ }^{244} \mathrm{Cm}$ Intake by Bioassay Measurements Following a Contamination Incident," J. Radioanal. Nucl. Chem. 138, 73-81 (1990)

Thompson, J.S., Pegg, D.J., Compton, R.N., and Alton, G.D., "Angular Distributions of Electrons from the Photodetachment of Metastable He-," J. Phys. B: At. Mol. Opt. Phys. 23, L15-L20 (1990)

Thomnson, J.S., Pegg, D.J., Dellwo, J., Compton, R.N., and Alton, G.D., "Photodetachment of Metastable He-" Nucl. Instrum. Methods Phys. Res. B 56/57, 211 $15(1991)$

Thompson, J.S., Pegg, D.J., Dellwo, J., Compton, R.N., and Alton, G.D., "Photodetachment of Metastable He-," Nucl. Instrum. Methods 56/57, 211-15 (1991)

Thornton, H.C., Krause, C., Russell, M., Pennycook, S., Sorensen, J., Eckerman, K., and Hawthorne, A., Oak Ridge National Laboratory Review, Vol. 23, No. 1, March 1990, ORNL/M-1113

Tiner, P.F. and Uziel, M.S., Field Observation Report for the K-1047-C Retention Basin at the Oak Ridge K-25 Site, Oak Ridge, Tennessee, ORNL/M-1499

Travis, C.C., White, R.K., and Ward, R.C., "Interspecies Extrapolation of Pharmacokinetics, " J. Theor. Biol. 142, 285-304 (1990)

Travis, C.C., Saulsbury, A.W., and Richter Pack, S.A., "Prediction of Cancer Potency Using a Battery of Mutation and Toxicity Data," Mutagenesis 5, 213-19 (1990)

Travis, C.C., "Tissue Dosimetry for Reactive Metabolites," Risk Anal. 10, 317-21 (1990)

Travis, C.C., Richter Pack, S.A., Yambert, M.W., and Saulsbury, A.W., "Prediction of Carcinogenic Potency from Toxicological Data," Mutat. Res. 241, 21-36 (1990)

Travis, C.C. and Hattemer-Frey, H.A., "Pharmacokinetics and Its Application to Kisk Assessment," Hazard Evaluation of Chemicals: Current Developments, Hemisphere Publ. Co., 1990, v. 7, pp. 39-82

Travis, C.C. and Hattemer-Frey, H.A., "Concentration of TC.DD in Fish and the Potential for Human Exposure," Environ. Int. 16, 155-62 (1990)

Travis, C.C., Quillen, J.L., and Arms, A.D., "Pharmacokinetics of Benzene," Toxicol. Appl. Pharmacol. 102, 400-20 (1990) 
Travis, C.C. and Land, M.L., "Estimating the Mean of Data Sets with Non-Detectable Values," Environ. Sci. Technol. 24, 961-62 (1990)

Travis, C.C. and Hattemer-Frey, H.A., "Physiological Pharmacokinetic Models," Statistics in Toxicology Research, Gordon \& Breach Science, 1991, pp. 161-90

Travis, C.C. and Bowers, J.C., "Altered Pharmacokinetics of Soil-Adsorbed Benzene Administered Orally in the Rat," Bull. Environ. Contam. Toxicol. 45, 197-207 (1990)

Travis, C.C. and Birkner, P.D., "Druckery Slope Controlled by Mitotic Rate of Enzymatically-Altered Foci," J. Theor. Biol. 149, 217-27 (1990)

Travis, C.C. and Hattemer-Frey, H.A., "Dioxin: Research Needs for Risk Assessment," Chemosphere 20, 729-42 (1990)

Travis, C.C. and Hattemer-Frey, H.A., "Human Exposure to Dioxin," Sci. Total Environ. 104, 97-127 (1991)

Travis, C.C. and Hattemer-Frey, H.A., "Letter to the Editor on the Carcinogencity of Radon," Environ. Sci. Technol. 24, 272 (1990)

Travis, C.C. and Hester, S.T., "Background Exposure to Chemicals: What is the Risk?" Risk Anal. 10, 463-66 (1990)

Travis, C.C., Wang, L.A., and Waehner, M.J., "Quantitative Correlation of Carcinogenic Potency with Four Different Classes of Short-Term Test Data," Mutagenesis 6, 353-60 (1991)

Travis, C.C. and Doty, C.B., "Can Contaminated Aquifers at Superfund Sites be Remediated?" Environ. Sci. Technol. 24, 1464-66 (1990)

Travis, C.C. and Hester, S.T., "Global Chemical Pollution," Environ. Sci. Technol. 25, 814-19(1991)

Travis, C.C., Craig, P.H., and Bowers, J.C., "Characterization of Human Exposure to Ambient Levels of Benzene Using Pulmonary 'Wash-Out' Data," Atmos. Environ. 25A, 1643-47 (1991)

Travis, C.C., McClain, T.W., and Birkner, P.D., "Diethylnitrosamine-Induced Hepatocarcinogenesis in Rats: A Theoretical Study," Toxicol. Appl. Pharmacol. 109, 289-304 (1991)

Tsai, D.P., Jackson, H.E., Reddick, R.C., Sharp, S.H., and Warmack, R.J., "Photon Scanning Tunneling Microscope Study of Optical Waveguides," Appl. Phys. Lett. 56, 1515-17 (1990)

Tuminello, P.S., Arakawa, E.T., Inagaki, T., and Parks, J.E., II, "Optical Response of Liquid Mercury," J. Chem. Phys. 95, 4790-95 (1991) 
Turner, J.E., Hamm, R.N., Huston, T.E., Wright, H.A., Gibson, W.A., and Hurst, G.S., "Concept for a Neutron Spectrometer Based on Optical Detection of ${ }^{3} \mathrm{He}(\mathrm{n}, \mathrm{p}){ }^{3} \mathrm{H}$ Reactions in a Gas," Radiat. Prot. Dosim. 32, 157-62 (1990)

Turner, J.E., "NCRP Report No. 101, Exposure of the U.S. Population from Occupational Radiation," Radiat. Res. 121, 344.45 (1990)

Turner, J.E., Bolch, W.E., Yoshida, H., Jacobson, K.B., Wright, H.A., Hamm, R.N., Ritchie, R.H., and Klots, C.E., "Radiation Damage to a Biomolecule: New Physical Model Successfully Traces Molecular Events," Appl. Radiat. Isot. 42, 995-1001 (1991)

Turner, J.E. and Huston, T.E., "ALDOSE: A Computer Code to Calculate AbsorbedDose Rate, Dose-Equivalent Rate, and Dose-Weighted LET as Functions of Depth in Water Irradiated by an Alpha-Particle Disc Source," Health Phys. 60, 581-85 (1991)

Turner, J.E., Hamm, R.N., Huston, T.E., Wright, H.A., Gibson, W.A., and Hurst, G.S., A Neutron Spectrometer Based on Optical Detection of ${ }^{3} \mathrm{He}(n, \mathrm{p})^{3} \mathrm{H}$ Reactions in a Gas, ORNL/TM-11531

Turner, J.E., "The Dosimetry of Ionizing Radiation, Vol. III - Book Review," Radiat. Res. 125, 114-15 (1991)

Turner, J.E., Hingerty, B.E., England, M.W., and Jacobson, K.B., "Calculated Distortions Induced by Metal-Ion Binding to Simple Oligonucleotide Systems: Implications for Toxicity," Proc. 4th Int. Workshop on QSAR in Environmental Toxicology, Veldhoven, The Netherlands, Sept. 16-20, 1990 (1990), p. 125

Tyndall, R.L., Ironside, K., Little, C.D., Katz, S., and Kennedy, J., "Free-Living Amoebae Used to Isolate Consortia Capable of Degrading Trichloroethylene," Appl. Biochem. Biotechnol. 28/29, 917-25 (1991)

Tyndall, R.L., "Protozoa," Guidelines for the Assessment of Bioaerosols in the Indoor Environment, American Conference of Governmental Industrial Hygienists, 1990, pp. 1-6

Tyndall, R.L., Bowman, E.K., Ironside, K.S., Milton, D., Barbaree, J., and Lehman, E., "Aerosolization of Microorganisms and Endotoxin from Home Humidifiers," Proc. Meet. Am. Soc. Microbiol., Dallas, May 5-9, 1991 (1991), p. 47

U.S. Public Health Service, Toxicological Profile for Chrysene, ORNL/M-1092

U.S. Public Health Service, Toxicological Profile for Benzo(b)fluoranthene, ORNL/M1091

U.S. Public Health Service, Toxicological Profile for Benz(a)anthracene, ORNL/M-1090

U.S. Public Health Service, Toxicological Profile for Dibenz(a,h)anthracene, ORNL/M1093 
U.S. Public Health Service, Toxicological Profile for Tetrachloroethylene, ORNL/M1076

U.S. Public Health Service, Toxicological Profile for Benzo|alpyrene, ORNL/M-1183

U.S. Public Health Service, Toxicological Profile for Lead, ORNL/M-1200

U.S. Public Health Service, Toxicological Profile for Trichloroethylene, ORNL/M-973

Uziel, M., Haglund, R., and White, D.A., "Persistence of Urinary Excretion Products of Benzo(a)pyrene," Polynuclear Aromatic Hydrocarbons: Measurements, Means and Metabolism, Proc. IIth Annu. Symp., Gaithersburg, MD, Sept. 23-25, 1987, Batelle Press, 1991, pp. 927-38

Uziel, M. and Houck, K., "Direct Labeling of DNA-Adducts Formed from Carcinogenic Diol-Epoxides with a Fluorescent Reporter Compound Specific for the Cis Vic-Diol Group," Biochem. Biophys. Res. Commun. 180, 1233-40 (1991)

Uziel, M.S., Tiner, P.F., and Williams, J.K., Surface Radiological Investigations of Trench 6 and Low-Level Waste Line Leak Site 7.4b at the Oak Ridge National Laboratory, Oak Ridge, Tennessee, ORNL/ER-37

Vlahoyannis, Y.P., Patsilinakou, E., Fotakis, C., and Stockdale, J.A.D., "LaserInduced Particle Generation in Carbon Disulfide and Carbonyl Sulfide," Radiat. Phys. Chem. 36, 523-28 (1990)

Vo-Dinh, T., "Laser Induced Luminescence Spectroscopy on Solid Substrates: An Overview," Proc. Am. Soc. Test. Mater. Symp. on Laser Techniques in Luminescence Spectroscopy, Boston, Nov.1, 1988, Am. Soc. Test. Mater. Spec. Tech. Publ. 1066, 1990, pp. 133-43,

Vo-Dinh, T., Nolan, T., Cheng, Y.F., Sepaniak, M.J., and Alarie, J.P., "PhaseResolved Fiber-Optics Fluoroimmunosensor," Appl. Spectrosc. 44, 128-32 (199())

Vo-Dinh, T., Alarie, J.P., Johnson, R.W., Sepaniak, M.J., and Santella, R.M., "Evaluation of Fiber-Optic Antibody-Based Fluoroimmunosensor for DNA-Adducts in Human Placenta Samples," Clin. Chem. 37, 532-35 (1991)

Vo-Dinh, T. and Pal, T., Development of a Spectrochemical Modification (SM) Technique to etect Permeation of Chemical Warfare Agent Simulants Through Protective Clothing Materials, ORNL/TM-11915

Wachter, E.A., Haas, J.W., III, James, D.R., Gammage, R.B., Ferrell, T.L., and Vo-Dinh, T., "Advances in Surface-Enhanced Raman Spectroscopy for Hazardous Waste Monitoring," Raman and Luminescence Spectroscopies in Technology II, Proc. Int. Symp. on Optical and Optoelectronic Applied Science and Engineering, San Diego, July 8-13, 1990, Soc. Photo-Opt., v. 1336, pp. 256-62

Wachter, E.A., Wilson, D.L., Dudney, C.S., and Haas, J.W., III, Work Plan. Mealth and Safety Plan, and Site Characterization for Soil Gas Survey at the Tank 2315-U Site, Pine Ridge East Repeater Station, ORNL/M-1220 
Walter, K., White, R.K., Southworth, G., O'Donnell, F., Travis, C., and White, D., Analysis of Proposed Post-Closure Alternatives for the Bear Creek Burial Grounds, ORNL/M-1045

Warmack, R.J., "Techniques of Scanning Probe Microscopy," Proc. U.S.-Japan Workshop on Atomic Collisions in Solids, Honolulu, Feb. 2-9, 1990, CONF900276,1990

Wassom, J.S. and Von Halle, E.S., "Mutation Research and the Literature of Genetic Toxicology - Another Milestone," Mutat. Res. 250, 499-502 (1991)

Watson, A.P., "Pesticide Facts Handbook by U.S. EPA," Environ. Manage. 14, 280-81 (1990)

Watson, A.P. and Munro, N.B., Reentry Planning: The Technical Basis for Offsite Recovery Following Warfare Agent Contamination, ORNL-6628

White, R.K., "Book Reviews for the Journal of Risk Analysis, March 1990," Risk Anai. 10, 191-93 (1990)

Williams, J.K., Rodriguez, R.E., Uziel, M.S., and Tiner, P.F., Surface Radiological Investigations at White Wing Scrap Yard, Oak Ridge Reservation, Oak Ridge, Tennessee, ORNL/ER-52

Williams, M.W., Arakawa, E.T., and Inagaki, T., "Optical and Dielectric Properties of Materials Relevant to Biological Research," Handbook on Synchrotron Radiation, Elsevier Science Publ., 1991, v. 4, pp. 95-145

Wilson, D.L., Gammage, R.B., and Matthews, T.G., "First-Phase Study Design for the U.S. Navy Radon Assessment and Mitigation Program (NAVRAMP)," Proc. Int Conf. on Indoor Air quality and Climate, Toronto, July 29-Aug. 2, 1990 (1990), v. 3 , pp. $107-12$

Wilson, D.L., Garnmage, R.B., Dudney, C.S., and Saultz, R.J., "Summertime Elevation of ${ }^{222 R n}$ Levels in Huntsville, AL," Health Phys. 60, 189-97 (1991)

Wilson, D.L., Dudney, C.S., and Gammage, R.B., "Quality Assurance and Control of Passive Radon Monitors," Abstract Book, American Industrial Hygiene Conf., Salt Lake City, May 19-24, 1991 (1991), p. 65

Wilson, M.J. and Crutcher, J.W., Determination of the Probability for Radioactive Materials on Properties in Monticello, Utah, ORNL/TM-11682

Wilson, M.J. and Crutcher, J.W., Results of the Independent Verification of Radiological Remedial Action at 87 East 500 South Street, Monticello, Utah (MSO0153), ORNL/RASA- 91/2

Wilson, M.J. and Crutcher, J.W., Results of the Independent Verification of Radiological Remedial Action at 397 East 3rd South Street, Monticello, Utah (MS00168), ORNL/RASA- 91/1 
Wilson, M.J. and Crutcher, J.W., Results of the Independent Verification of Radiological Remedial Action at 16 East 5th South Street, Monticello, Utah (MS00075), ORNL/RASA-91/5

Wilson, M.J. and Crutcher, J.W., Results of the Independent Verification of Radiological Remedial Action at 464 South 1st East Street, Monticello, Utah (MS00071), ORNL/RASA-91/4

Wilson, M.J. and Crutcher, J.W., Results of the Independent Verification of Radiological Remedial Action at 600 South Clayhill Drive (AKA 600 South Cemetery Road), Monticello, Utah (MSO0145), ORNL/RASA-91/3

Wright, H.A., Hamm, R.N., Turner, J.E., Howell, R.W., Rao, D.V., and Sastry, K.S.R., "Calculations of Physical and Chemical Reactions with DNA in Aqueous Solution from Auger Cascades," Radiat. Prot. Dosim. 31, 59-62 (1990)

Wunderlich, R.K., Moore, M.A., Garrett, W.R., and Payne, M.G., "Nonlinear Optical Processes Near the Sodium 4D Two-Photon Resonance," Phys. Rev. A 41, 6345-60) (1990)

Yoshida, H., Bolch, W.E., Jacobson, K.B., and Turner, J.E., "Measurement of Free Ammonia Produced by X-Irradiation of Glycylglycine in Aqueous Solutions," Radiat. Res. 121, 257-61 (1990)

Yoshida, H., Bolch, W.E., Turner, J.E., and Jacobson, K.B., "The Radiation Chernistry of Glycylglycine in Aqueous Solutions," Radiat. Prot. Dosim. 31, 67-70) (1990)

Young, R.A. and Weil, D., "Toxicology and Quantitative Risk Assessment for Mercury," The Toxicologist 10, 352 (1990)

Young, R.A., Daugherty, M.W., Talmage, S.S., and McKean, D., "An Overview of the Toxicology of Methyl Methacrylate," The Toxicologist 11, 243 (1991)

Young, R.A., Davidson, K.A., Martin, F.M., Daugherty, M.W., Pal, B.C., and Opresko, D.M., The Installation Restoration Program Toxicology Guide, Volume 5, ORNL/M-975/V5

Yust, L.N., Adamson, A.E., Casey, D.K., Wyrick, J.M., Davidson, K.A., and Mansfield, B.K., DOE Human Genome Program Report of the Second ContractorGrantee Workshop, Santa Fe, NM, February 17-20, 1991, ORNL, 1991 CONF-9102129

Zheng, X., Ritchie, R.H., and Manson, J.R., "High-Order Corrections to the Binding Energy of Image States," Physica B 157, K87-K91 (1990)

Zheng, X.-Y. and Ritchie, R.H., "Image Potential for an Electron Near an Impenetrable Surface," Phys. Rev. B 43, 6493-97 (1991) 
ORNL -6693

Dist. Category UC-407

\section{INTERNAL DISTRIBUTION}

1. W. J, Allen

2. D. P. Allison

3. S. L. Allman

4. K. R. Ambrose

5. E. T. Arakawa

6. A. Q. Armstrong

7. J. C. Ashley

8. S. Auerbach

9. J. B. Ball

10. C. B. Bast

11. B. A. Berven

12. H. T. Borges

13. P. A. Brimer

14. K. J. Brown

15. M. M. Brown

16. M. A. Buckner

17. A. P. Callahan

18. T. A. Callcott

19. H. S. Carman, Jr.

20. R. F. Carrier

21. J. G. Carter

22. W. H. Casson

23. G. M. Caton

24. S. S. Chang

25. C. H. Chen

26. L. G. Christophorou

27. R. N. Compton

28. W. D. Cottrell

29. O. H. Crawford

30. M. T. Cristy

31. T. A. Cronk

32. G. S. Danford

33. M. W. Daugherty

34. K. A. Davidson

35. H. C. Dees

36. K. S. Dickerson

37. C. E. Dixon

38. D. M. Douthat

39. C. S. Dudney

40. M. D. Dykes

41. C. E. Easterly

42. K. F. Eckerman

43. A. R. Ehrenshaft

44. A. E. Ekkebus

45-47. J. R. Ellis

48. M. W. England
49. M. L. Espegren

50. E. L. Etnier

51. R, A, Faust

52. R. E. Fenstermaker

53. T. L. Ferrell

54. D. E. Fields

55. L. M. Floyd

56. R, D. Foley

57. A. A. Francis

58. M. W. Francis

59. R. B. Gammage

60. F. G. Gardner

61. W. R. Garrett

62. R. K. Genung

6\%. D. W. Greene

64. G. D. Griffin

65. J. D. Griffin

66. J. W. Haas, III

67. R. T. Haas

68. D, K. Halford

69. S. C. Hall

70. R. N. Hamm

71. F. C. Hartman

72. G. T. Hawkins

73. C. G. Heckman

74. B. E. Hingerty

75. L. M. Houlberg

76. P. S. Hovatter

77. S. M. Hubner

78. D. R. James

79. C. A. Johnson

80. T. D. Jones

81-130. S. V. Kaye

131. G. D. Kerr

132. B. W. Kline

133. C. E. Klots

134. F. F. Knapp, Jr.

135. D. C. Kocher

136. B. J. Krall

137. E. H. Kreig, Jr.

138. M. L. Land

139. D. C. Landguth

140. R. W. Leggerl

141. E. B. Lewis

142-151. C. A. Little

152. P. Y. Lu 
153. C. A. Ludemann

154. B. K. Mansfield

155. K. H. Mavournin

156. L. M. McDowell-Boyer

157. C. W. McGinn

158. S. P. McKenzle

159. D. W. McPherson

160. D. B. Miller

161. I. C. Miller

162. J. C. Miller

163. P. D. Miller

164. S. Mirzadeh

165. O. B. Morgan

166. J. M. Morris

167. C. A. Muhr

168. N. B. Munro

169. M. E. Murray

170, G. W. Oliphant

171. D. M. Opresko

172. E. T. Owens

173. J. E. Peterson

174. D, A. Pickering

175. L. A. Pinnaduwage

176. M. L. Poutsma

177-178. D. E. Reichle

179. A. A. Richmond

180. R. H. Ritchie

181. J. B. Roberto

182. R. E. Rodriguez

183. P. S. Rohwer

184. R. H. Ross

185. I. Sauers

186. J. Sheffield

187. W. D. Shults

188. C. S. Sims

189. J. L. Skiles

190. K. G. Slusher

191. D. R. Smuin

192. P. C. Srivastava

193. M. E. Stack

194. R. S. Stafford

195. G. H. Stevens

196. J. M. Stockstill

197. R. E. Swaja

198. S. S. Talmage

199. J. E. Thate

200. J. K. Thomas

201. D. J. Thorne

202. C. C. Travis

203. D. B. Trauger

204. J. L. Trimble

205. J. E. Turner
206. R. L. Tyndall

207. S. Y. Uppuluri

208. M. Uziel

209. M. S. Uziel

210. R. I. Van Hook

211. T. Vo-Dinh

212. E. A. Wachter

213. S. J. Wallace

214. R. C. Ward

215. R. J. Warmack

216. J. S. Wassom

217. D. A. Waters

218. A. P. Watson

219. R. K. White

220. B. L. Whitfield

221. J. K. Williams

222. D. L. Wilson

223. L. A. Wilson

224. M. J. Wilson

225. K. M. Woynowskie

226. H. Yoshida

227. R. A. Young

228. E. A. Zeighami

229. Biology Division Library

230-231. Central Research Library

232. CRL-Document Reference Section

233-237. Laboratory Records

238. Laboratory Records - RC

239. Patent Office 


\section{EXTERNAL DISTRIBUTION}

240. S. Acharya, Nuclear Regulatory Commission, MS P-822, Washington, DC 20555

241. T. E. Aldrich, Central Cancer Registry; Cancer Surveillance Section, P. O. Box 27687, Raleigh, NC 27611.7687

242. R. E. Alexander, The Alexander Corporation, 13131 Maltese Lane, Fuirfax, VA 22033

243. J. R. Anderson, Department of Energy, 5301 Central Avenue NE, Albuquerque, NM 87115

244. C. M. Auer, Director, Existing Chemical Assessment Division (TS-778), Environmental Protection Agency, 401 M St., S.W., Washington, DC 20460

245. J. Auxier, IT Corporation, 312 Directors Drive, Knoxville, TN 37923

246. W. Bair, Pacific-Northwest Laboratory, Battelle Boulevard, P. O. Box 999, Richland, WA 99352

247. J. N. Bardsley, Lawrence Livermore National Laboratory, MS L-296, Livermore, CA 94550

248. J. Barkley, Army Biomedical Research and Development Laboratory, He.lth Effects Research Division, Fort Detrick, Frederick, MD 21701

249. N. F. Barr, Office of Health and Environmental Research, ER-72, Department of Energy, Washington, DC 20585

250. J. E. Baublitz, Office of Environmental Restoration and Waste Management, EM-423, Department of Energy, Washington, DC 20585

251. J. M. Becker, Microbiology Department, University of Tennessee, Knoxville, TN 37916

252. H. M. Borella, EG\&G, Inc., Santa Barbara Operations, 130 Robin Hill Road, Goleta, CA 93117

253. J. N. Bradford, RADC/ESR, Hanscom AFB, MA 01731

254. A. B. Brill, University of Massachusetts Medical School, Department of Nuclear Medicine, Worcester, MA 01605

255. J. Broadway, Environmental Protection Agency, P. O. Box 3009, Montgomery, AL 36109

256. A. Brodsky, Allen B. Consultants, Inc., 16412 Kipling Road, Derwood, MD 20855-1927 
257. P. A, Buffler, Professor of Epldemiology and Associate Dean for Reseurch, University of Texas at Houston, School of Public Health, P. O. Box 20186, Houston, TX 77025

258. G. Burger, Gesellschaft fur Strahlen und Umweltforschung, 8042 Neuherberg, Ingolstadter Landstrasse 1, Munich, Federal Republic of Germany

259. T. A. Butler, 119 Dana Drive, Oak Ridge, TN 37830

260. J. R. Cameron, University of Wisconsin Medical Center, Department of Radiology, 130)( University Avenue, Madison, WI 537)6

261. A. W. Castleman, Pennsylvania State University, College of Science, 152 Davey Laboratory, University Park, PA 16802

262. A. Chatterjee, Lawrence Berkeley Laboratory, University of California, Berkeley, CA 94720

263. R. J. Cloutier, Energy/Environment System Division, Oak Ridge Associated Universities, Oak Ridge, TN 37830

264. C. B. Coburn, Jr., Biology Department, Tennessee Technological University, Campus Box 5127, Cookeville, TN 385()1

265. D. W. Cole, Office of Health and Environmental Research, ER-73, Department of Energy, Washington, DC 20585

266. F. J. Congel, Division of Systems Integration, Office of Nuclear Reactor Regulation, Nuclear Regulatory Commission, Washington, DC 20545

267. W. K. Cook, P.E., Senior Vice President, ATEC Associates, Inc., 1300 Williams Drive, Suite A, Marietta, GA 30066-6299

268. T. W. Crawford, Savannah River Company, P. O. Box 616, Aiken, SC 29801

269. L. T. Dillman, 184 West Lincoln Avenue, Delaware, OH 43015

270. L. J. Doemeny, Deputy Director, Physical Sciences and Engineering Division, NIOSH, 4676 Columbia Parkway, Cincinnati, OH 45266

271. P. M. Echenique, Departmento de Fisica de Materiales, Universidad del Pais Vasco, 20080 San Sebastian, Spain

272. W. H. Farland, Director, Office of Health and Environmental Assessment, MS RD-689, Environmental Protection Agency, 401 M Street SW, Washington, DC 20460)

273. D. J, Fehringer, Nuclear Regulatory Commission, MS-623-SS, Washington, DC 20555 
274. C. Feldman, Office of Standards Development, Nuclear Regulatory Commission, MS-1130SS, Washington, DC 20555

275. P. Fenner-Crisp, Office of Pesticide Program, H-75(19-C, Environmental Protection Agency, $401 \mathrm{M}$. Street SW East Tower, Washington, DC 20460

276. J. J. Fiore, Departınent of Energy, EM-423, Washington, DC 20585

277. D. R. Fisher, Pacific-Northwest Laboratory, Battelle Boulevard, P. O, Box 999, Rlchland, WA 99352

278. F. Flores, Departmento de Fisica del Estado Solido, Universidad Autonoma de Madrid Cantoblanco, Madrid, Spain

279. D. Fulmer, Department of Energy, EM-43, Washington, DC 20585

280. D. J. Galas, Associate Director, Office of Health and Environmental Research, ER-70, Department of Energy, Washington, DC 20585

281. J. H. Gibbons, Director, Office of Technology Assessment, Congress of the United States, Washington DC 20510

282. D. M. Goldenberg, Center for Molecular Medicine and Immunology, 100 Bergen Street, Newark, NJ 07103

283. G. Goldstein, Office of Health and Environmental Research, ER-74, Department of Energy, Washington, DC 20585

284. M. M. Goodman, Radiology Department, U.T. Memorial Hospital, 1924 Alcoa Highway, Knoxville, TN 37920

285. R. Goyer, Deputy Director, National Institute of Environmental Health Solences, P. O. Box 12233, Research Triangle Park, NC 27709

286. D. Greathouse, Environmental Protection Agency, 26 W. St. Clair, Cincinnati, OH 45268

287. R. A. Griesemer, National Institute of Environmental Health Sciences, P. O. Box 12233, Research Triangle Park, NC 27709

288. E. J. Hall, Radiological Research Laboratory, College of Physicians and Surgeons of Columbia University, 630 West 168th Street, New York, NY 10032

289. T. Harvey, Director, Environmental Criteria and Assessment Office, Environmental Protection Agency, 26 W. St. Clair, Cincinnati, OH 45268

290. G. Heuter, Environmental Protection Agency, Research Triangle Park, NC 27711 
29)1. S. Hossuin, Division of Nuclear Fuel Cycle and Waste Management, IAEA, Wagramerstrasse 5, P. O, Box 100, A-1400) Vienna, Austrla

292. A. Howie, Cavendish Laboratory, Madingley Road, Cambridge CB30HE, England

293. J, H. Hubbell, Center for Radiation Research, National Institute of Standards and Technology, Washington, DC 20434

294. S. R. Hunter, Pellissippi International, 114 Ridgeway Conter, Oak Ridge, TN 3783()

295. G. S. Hurst, Consultec Scientific, Inc., Pellissippl Center, Sulte 110, 725 Pellissippi Purkway, Knoxville, TN 37932-330()

296. T. Inagaki, Department of Physics, Osaka Kyoiku University, Tennoji, Osaka, 543 Japan

297. B. Jinkerson, University Programs Division, Oak Ridge Associated Universities, P. O. Box 117, Oak Ridge, TN 37831

298. R. Katz, Department of Physics, University of Nebraska, Lincoln, NE 68588

299. T. W. Kerlin, Department of Nuclear Engineering, 315 Pasqua Building, University of Tennessee, Knoxville, TN 37996

30), G, Killough, 105 Netherland Rd, Oak Ridge, TN 37830)

301. W. E. Legg, Army Environmental Hygiene Agency (ATTN: HSHB-ME-SR), Aberdeen Proving Ground, MD 210110 -.5422

3()2. J. C. Lehr, Department of Energy, EM-442, Washington, DC 20585

3()3. R. Lightner, DOE, EM-45, Washington, DC 20585

304. W. C. Lineberger, Department of Chemistry and Joint Institute for Laboratory Astrophysics, University of Colorado, Boulder, CO 8()3()2

3()5. D. T. Mage, Senior Scientific Advisor, Data Management and Analysis Division (MD-56), EPA/EMSL, Research Triangle Park, NC 27711

3()6. J. L. Magee, Biology and Medicine Department, University of Callfornia, Berkeley, CA 94720

3()7. S. A. Mann, Department of Energy, EM-451, Washington, DC 20585

308. J. R. Manson, Department of Physics, Clemson University, Clemson, SC 29631

309. M. L. Matthews, UMTRA Project Office, Department of Energy, 5301 Central Ave., NE, Suite 170(), Albuquerque, NM 87108 
310. T. J, McKenna, Office of Inspection and Enforcement, MS EWW-359, Nuclear Regulatory Commission, Washington, DC 20555

311. C. B. Meinhold, President, NCRP, 7910 Woodmont Avenue, Suite 800, Bethesda, MD 20814

312. E. Merzbacher, Professor, Department of Physics and Astronomy, University of North Carolina, Chapel Hill, NC 27599

313. C. W. Miller, Office of Nuclear Facility Safety, Illinois Department of Nuclear Safety, 1035 Outer Park Drive, Springfield, liL 62704

314. A. A. Moghissi, P.O. Box 7166, Alexandria, VA 22307

315. J. A. Morley, Department of Energy, Dayton Area Office, P.O. Box 66, Milamisburg, $\mathrm{OH} 45342$

316. P. E. Morrow, The University of Rochester School of Medicine and Dentistry, Rochester, NY 14620

317. C. B. Nelson, Environmental Protection Agency, ANR-461, Washington, DC 20460

318. D. R. Nelson, Office of Nuclear Safety, Department of Energy, EH 331.2, Washington, DC 20545

319. B. Parks, Office of Radiation Programs (ANR-460), Environmental Protection Agency, Washington, DC 20460

320. R. Perhac, Electric Power Research Institute, 3412 Hillview Avenue, P. O. Box 10412, Palo Alto, CA 94303

321. J. W. Poston, Department of Nuclear Engineering, Texas A\&M, College Station, TX 77843-3133

32. C. J. Powell, Electron Physics Section, National Institute of Standards and Technology, Washington, DC 20234

323. G. Purcell, Director, GGSLIS, The University of Tennessee, 804 Volunteer Boulevard, Knoxville, TN 37996-4330

324. D. P. Rall, Director, National Institute of Environmental Health Sciences, P. O. Box 12233, Research Triangle Park, NC 27709

325. A. Richardson, Office of Radiation Programs, Environmental Protection Agency, Crystal Mall \#2, 1921 Jefferson Davis Hwy., Crystal City, VA 22202

326. R. Rieger, Appalachian Regional Laboratory, NIOSH, Morgantown, WV 26505

327. S. L. Rose, Manager, Radon Research Program, Office of Health and Environmental Research, ER-73, Department of Energy, Washington, DC 2058.5 
328. G, S, Roessler, University of Florida, Department of Nuclear Engineering Sclences, Gainesville, FL 32611

329. B. A. Schwetz, Chief, Systemlo Toxicology Branch, NIEHS, P. O. Box 12233, Research Triangle Park, NC 27709

330. R. F. Sena, Department of Energy, Environmental Restoration Project Office, P. O. Box 5400, Albuquerque, NM 87115

331. K. Sexton, Director, Office of Houlth Research, RD.683, Room 3100, Environmental Protection Agency, 401 M Street, SW, Washington, DC 2(046)

332. G. L. Sherwood, NE 52, Office of Nuclear Energy, MS-B107, Department of Energy, Washington, DC 20585

333. C. M. Shy, Department of Epidemiology, C.B. 8050, NCNB Plaza, Suite 32, University of North Carolina, Chapel Hill, NC 27599-8050

334. A. Sinkankas, The University of Tennessee, 804 Volunteer Boulevard, Temple Court, Room 304, Knoxville, TN 37996-4330

335. R. Snelling, Environmental Protection Agency, Las Vegas, NV 89193-3478

336. R. Snyder, Professor and Director, Department of Pharmacology and Toxicology, College of Pharmacy, Busch Campus, Rutgers University, Poscataway, NJ 08854

337. J. K. Soldat, Energy System Sigma, Pacific-Northwest Laboratory, Battelle Boulevard, Richland, WA 99352

338. D. Straw, W. J. Schafer Associates, Inc., 1600 Randolph Courı SE, \#2, Albuquerque, NM 87106

339. R. E. Sullivan, Office of Radiation Prograns (AHR-460), Environmental Protection Agency, Crystal City, VA 22202

340. J. W. Thiessen, Radiation Effects Research Foundation, 5-2 Hijiyama Park, Minani-ku, Hiroshima 732, Japan

341. J. E. Thompson, Associate Professor, College of Law, University of Tennessee, 1505 W. Cumberland Avenue, Knoxville, TN 37996-1800

342. L. H. Toburen, Pacific-Northwest Laboratory, Battelle Boulevard, P. O. Box 999, Richland, WA 99352

343. A. Ulsarner, Consumer Product Safety Commission, 5401 Westbard Avenue, Washington, DC 20207

344. M.Varma, Pollutant Characterization and Safety, Office of Health and Environmental Research, ER-74, Department of Energy, Washington, DC 20.585 
345. J. M. Veigel, President, Oak Ridge Associated Universities, 130 Badger Avenue, Oak Ridge, TN 37830

346. Col. Erik K. Vermulen, Director, Department of the Air Force, Armstrong Laboratory (AFSC), Wright-Patterson Air Force Base, Ohio 45433-6573

347. J. Villforth, Bureau of Radiological Health, U.S. Public Health Service, 5600 Fishers Lane, Parklawn Building, Rockville, MD 20582

348. P. Voytek, Vice President, Clement Associates, 9300 Lee Highway, Fairfax, VA 22031-1207

349. B. Wallace, Appalachian Regional Laboratory, NIOSH, Morgantown, WV 26505

350. A. Wallo, Department of Energy, EH-231, 1000 Independence Avenue, Washington, DC 20581

351. P. J. Walsh, H \& R Technical Associates, Inc., P. O. Box 4159, Oak Ridge, TN 37831-4159

352. W. L. Ward, American Petroleum Institute, 1220 L Street NW, Washington, DC 20005

353. M. D. Waters, Director, Genetic Toxicology Division, Environmental Protection Agency, Health Effects Research Laboratory, Research Triangle Park, NC 27711

354. J. E. Watson, 517 Yorktown Drive, Chapel Hill, NC 27514

355. W. Weyzen, Electric Power Research Institute, 3412 Hillview Avenue, P. O. Box 10412, Palo Alto, CA 94303

356. F. W. Whicker, Senior Scientist, Savannah River Ecology Laboratory, Drawer E, Aiken, SC 29801

357. R. P. Whitfield, Department of Energy, EM-40, Washington, DC 20585

358. L. R. Williams, Environmental Protection Agency-QAD, Environmental Monitoring System Laboratory, P. O. Box 93478, Las Vegas, NV 89193-3478

359. R. Wirtz, Dean, College of Law, University of Tennessee, 1505 W. Cumberland Avenue, Knoxville, TN 37996-1800

360. R. W. Wood, Acting Director, Medical Applications and Biophysical Research Division, Office of Health and Environmental Research, ER-74, Department of Energy, Washington, DC 20585

361. H. A. Wright, Consultec Scientific, Inc., Pellissippi Center, 725 Pellissippi Parkway, Knoxville, TN 37932-3300 
362. H. O. Wyckuff, 4108 Montpelier Road, Rockville, MD 20854

363. Deputy Assistant Manager, Energy Research and Development, Department of Energy, DOE Oak Ridge Field Office, P. O. 2008, Oak Ridge, TN 37831-62.69

364-407. Given distribution as shown in DOE/OSTI-4500 under UC-407, Health and Safety 

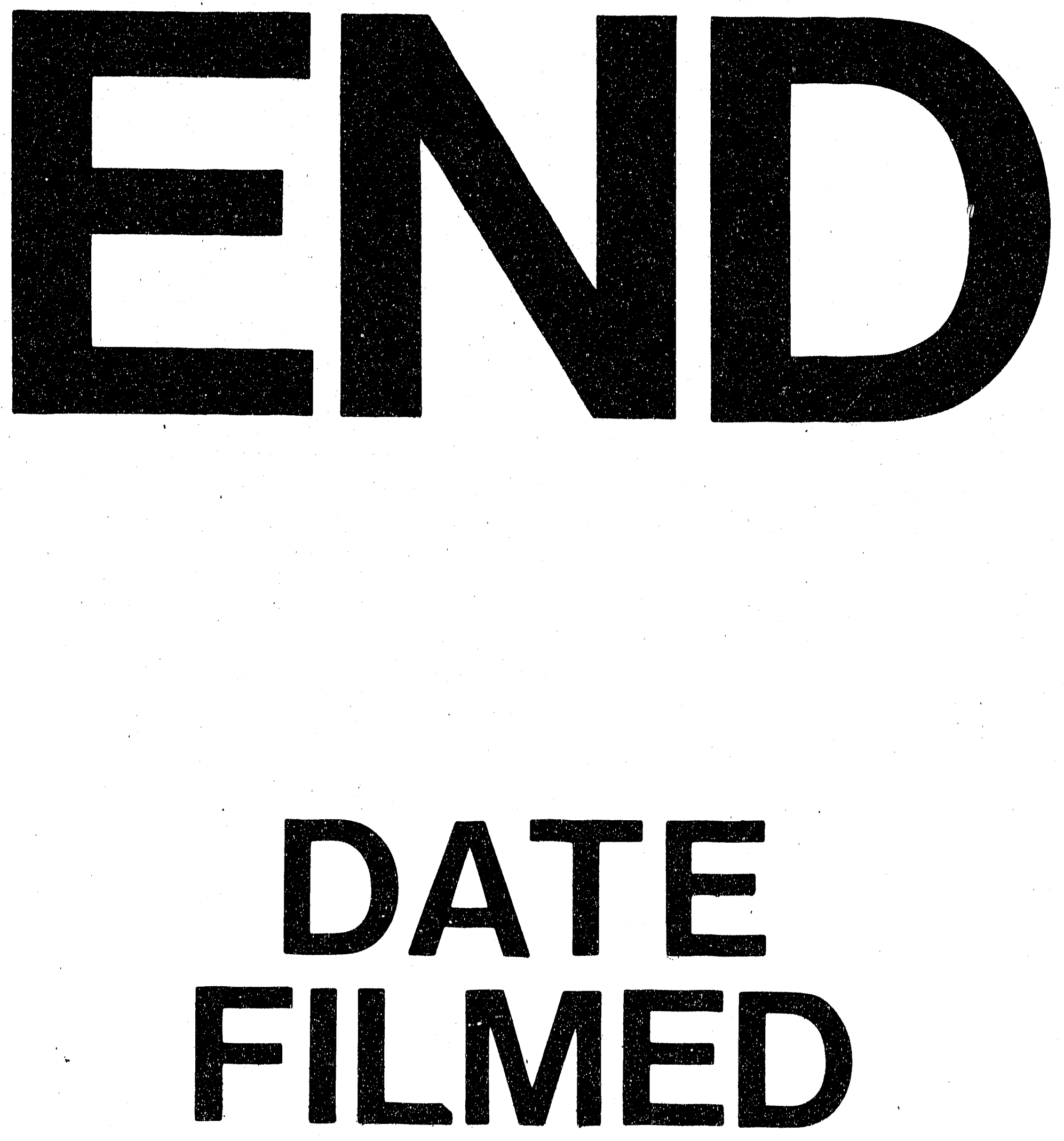

$\overrightarrow{3}$

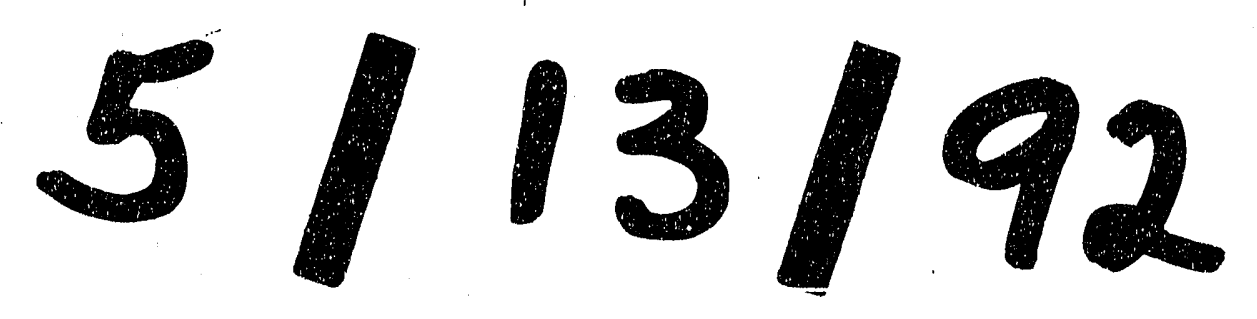


